\title{
Identifying Multiple Deep Aquifers in the Bengal Basin: Implications for Resource Management
}

\begin{tabular}{|r|l|}
\hline Journal: & Hydrological Processes \\
\hline Manuscript ID & HYP-17-0651.R2 \\
\hline Wiley - Manuscript type: & Research Article \\
\hline Complete List of Authors: & $\begin{array}{l}\text { Ravenscroft, Peter; Self Employed, Not applicable } \\
\text { McArthur, John; University College London, Earth Sciences } \\
\text { Rahman, Md; Department of Public Health Engineering, R\&D Division }\end{array}$ \\
\hline Keywords: & $\begin{array}{l}\text { Deep aquifer, Bangladesh, India, Bengal Basin, arsenic, groundwater } \\
\text { resource management }\end{array}$ \\
\hline \multicolumn{2}{|c}{} \\
\hline
\end{tabular}

SCHOLARONE ${ }^{\text {H }}$

Manuscripts 


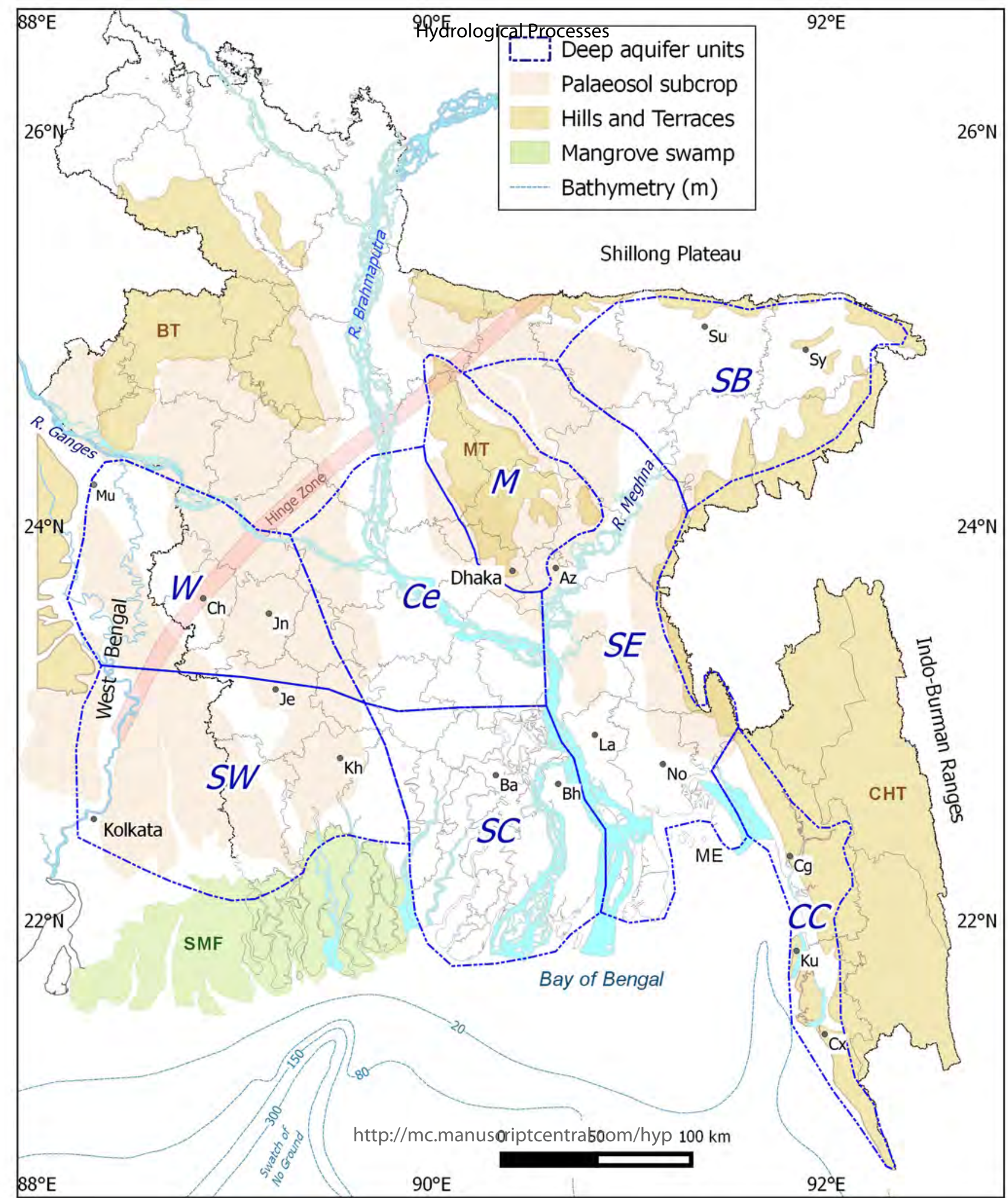




\title{
Identifying Multiple Deep Aquifers in the Bengal Basin: Implications for Resource Management
}

\author{
P. Ravenscroft ${ }^{*} \dagger$, J.M. McArthur ${ }^{\S}$, M.S. Rahman" \\ ${ }^{* \dagger}$ Consultant Hydrogeologist, Cambridge, UK \\ ${ }^{\S}$ Earth Sciences, University College London, Gower Street, London WC1E 6BT \\ " Department of Public Health Engineering, DPHE Bhaban, 14, Shaheed Captain Mansur Ali Sarani, \\ Kakrail, Dhaka-1000, Bangladesh
}

Keywords:

Deep aquifer, Bangladesh, India, Bengal Basin, arsenic, groundwater resource management 


\section{Abstract.}

In the Bengal Basin of Bangladesh and West Bengal (India), where arsenic and salinity adversely affect groundwater in shallow aquifers $(<150$ metres deep), consumers increasingly turn to 'the deep aquifer' as a source of low-arsenic and low-salinity water. We show that 'the deep aquifer', which has traditionally been regarded as a single entity, can be divided into at least eight deep aquifer units each with distinctive chemical, isotopic, hydraulic and piezometric characteristics. Except in the rapidly subsiding Sylhet Basin, the deep aquifers are largely arsenic-safe $(<50 \mu \mathrm{g} / \mathrm{L}$ and mostly $<10 \mu \mathrm{g} / \mathrm{L}$ ) but differ in terms of iron, manganese, salinity, stable isotopic composition, groundwater age, and in their piezometric response to pumping. We use isotopic data to identify recharge from five periods, of which two are quantitatively dominant: (i) from the Last Glacial Maximum, isotopically heavy water $\left(\delta^{18} \mathrm{O}>-3.5 \%\right.$ o with low $\mathrm{As}, \mathrm{Cl}$ and $\mathrm{Fe}$ concentrations occupies hydraulically trapped positions in the South-Central, Southeast, Southwest and Madhupur aquifer units; and (ii) terminal Pleistocene to early Holocene recharge of isotopically lighter water $\left(\delta^{18} \mathrm{O}<-3.5 \%\right.$ ) which has high $\mathrm{Fe}$ and slightly elevated $\mathrm{Cl}$ concentrations, and was recharged along palaeochannels that facilitated deep circulation up to the mid-Holocene. Piezometric responses to development change in style towards the coast. In the north, water levels at all depths tend to be coincident, and transition through a seasonally divergent pattern to become parallel in the south with a near-constant downward gradient. The delineation of the deep aquifer units provides a practical framework for assessment and management of groundwater resources for water-supply. 


\section{Introduction}

Groundwater, drawn from fluvial and deltaic sediments of the Ganges-Brahmaputra-Meghna (GBM) delta (the Bengal Basin), is the principal source of water for drinking, irrigation and industry in Bangladesh and West Bengal, India. Groundwater at depths of $<150 \mathrm{~m}$ is widely, but not uniformly, polluted with arsenic (As), a colourless, odourless, tasteless, carcinogen which has severely and adversely affected the health of tens of millions of consumers (Smith, Lingas, \& Rahman, 2000; Ravenscroft, Brammer, \& Richards, 2009). To compound the problem of As, groundwater in the Bengal Basin is widely contaminated by salinity, iron and manganese. Handpumped tubewells, the principal means of domestic supply, are also affected adversely by declining piezometric levels, which widely fall below suction limits (c. $7.5 \mathrm{~m}$ below ground level (m bgl)) for part of the year (e.g. Ravenscroft et al., 2014).

To mitigate the effects of As-pollution in shallow groundwater $(<150 \mathrm{~m} \mathrm{bgl})$, in some areas it is possible to obtain low-As water by increasing well depths by a few tens of metres but generally groundwater from depths $>150 \mathrm{~m}$ is the water source of choice because it is usually 'arsenic-safe' $(<10 \mu \mathrm{g} / \mathrm{L})$, has low salinity, is more aesthetically acceptable in terms of Fe and Mn, and so is popular with users albeit in defiance of government policy and subject to much concern over the sustainability of the resource (DPHE, 1999; ATF, 2004; GoB, 2004; Michael and Voss, 2008; Burgess et al., 2010; Mosler, Blöchliger, \& Inauen, 2010; LGD, 2011; Radloff et al., 2011), although it has been argued that the possible degradation of the resource to alleviate present Aspoisoning represents acceptable risk-substitution (Ravenscroft, McArthur, \& Hoque, 2013).

Here, we follow the local convention of using the terms 'deep aquifer' and 'deep tubewell' (DTW) to describe any aquifer or well deeper than $150 \mathrm{~m}$. To date 'the deep aquifer' has been insufficiently studied and treated as a monolithic resource i.e. a single unit, with the implicit understanding that it is essentially the same everywhere. This approach has been largely driven by a shortage of good information. We build on earlier suggestions (Ravenscroft, McArthur, \& Hoque, 
2001; Hoque, Burgess, \& Ahmed, 2008) that the deep aquifer may not be homogeneous and show that at least 8 distinct, contiguous deep aquifer units can be identified (Figure 1, Table 1).

It is difficult to define aquifer units at a scale applicable to water resource planning in a basin as large as the Bengal Basin. It is not practical to correlate the small-scale lithostratigraphical units such as beds and members over large distances, and there is no comprehensive Quaternary stratigraphical column (Alam, Hassan, Khan \& Whitney, 1990; Alam, Alam, Curray, Chowdhury, \& Gani, 2003). Although the properties of shallow aquifers have been correlated with geomorphological units (DPHE, 1999; Ravenscroft, 2003), this is less helpful for deeper aquifers. To produce a classification that is meaningful at a scale of $10^{1}$ to $10^{2} \mathrm{~km}$, we invoke geomorphological, hydrochemical, and hydraulic, evidence to delineate mappable deep aquifer units with distinctive properties and characteristic responses to development. Our definition of these units is similar to that of the European Water Framework Directive (WFD) which defines a groundwater body as "a distinct volume of groundwater within an aquifer or aquifers" (UKTAG, 2012). We then explore the implications of our findings for aquifer management.

\section{Geological and Hydrogeological Setting}

The geology of the GBM delta, and its tectonic equivalent the Bengal Basin, the largest Asian mega-delta, is described by Morgan and McIntire (1959), Goodbred (2003); Goodbred et al. (2014) and Wilson and Goodbred (2015), and its hydrogeology by MPO (1987), WARPO (2001), Ravenscroft (2003) and Michael and Voss (2009a) amongst others, while arsenic pollution of shallow aquifers is described by many authors including Nickson et al. (1998), DPHE (2001), McArthur, Ravenscroft, Safiullah, \& Thirlwall (2001), McArthur et al. (2004), Harvey et al. (2002); van Geen et al. (2003) and Zheng et al. (2005).

The importance of assessing the deep groundwater resource was recognised long ago (Morton \& Khan, 1979) but to date there has been limited explicit investigation (DPHE-JICA, 2002; Shibasaki, Lei, \& Kamata, 2007; BWDB, 2013) although some information comes from water supply projects 
(DPHE-DANIDA, 2001; BRGM, 2005; Ravenscroft et al., 2013) and preliminary basinal scale modelling (Michael \& Voss, 2008, 2009b; Burgess et al., 2010; Radloff et al., 2011).

Alluvial-deltaic sediments thicken from the northwest into the delta region where aquifers transition from coarse-grained, one or two-layered systems, to finer grained multi-layered aquifers. Aquifers of Plio-Pleistocene age are generally overlain by a few tens to more than a hundred metres of Holocene sediment and crop out along the eastern and western basin margins. The Holocene floodplains are interrupted by the terrace-like Madhupur and Barind Tracts which are surfaced by polyphase palaeosols (Alam et al., 1990; Goodbred, 2003; Brammer, 2012; Figure 1). Beneath the floodplains, buried palaeosols form important and extensive aquitards (McArthur et al., 2008; Hoque, McArthur, \& Sikdar, 2014a). The deep aquifers have similar permeabilities to shallow Pleistocene aquifers beneath the Madhupur and Barind Tracts but that deep aquifers in southeast Bangladesh could be twice as transmissive and have larger storage coefficients than those in the south-central region (Ravenscroft et al., 2013).

The history of incision and sediment aggradation, driven by eustatic sea-level change and glaciation in the Himalayas is fundamental to conceptualising the deep aquifers. The influence of these processes on the hydraulic and hydrochemical properties of shallow aquifers has been well demonstrated (e.g. BADC, 1992; DPHE, 1999; Ravenscroft et al., 2001; Shamsudduha \& Uddin, 2007) but their influence on deeper aquifers has received less attention. When global sea level last stood at its present level at around $125 \mathrm{Ka}$, the physiography would have been similar to today (e.g. Goodbred, 2003), though without human modification. After that time, global sea level underwent a long-term, fluctuating, decline until the Last Glacial Maximum (LGM) between about 30 and 18 Ka. Much of the space now occupied by the post-LGM aquifers was carved away to leave a system of terraces and incised channels. The deeper channels divided Bengal into geochemically altered upland interfluves, with redefined catchment boundaries and deep water-tables which discharged groundwater towards adjacent river channels. Hoque, McArthur, \& Sikdar (2012, 2014a) have mapped some of the buried palaeosol-capped interfluves but much less is known about the deep 
palaeochannels (Pickering et al., 2014, 2017) that controlled the discharge of groundwater. In addition, dependent on their position relative to the hinge zone (Figure 1), the deep aquifers underwent tens to perhaps more than a hundred metres of subsidence between interglacials (e.g. Johnson \& Alam, 1991; Goodbred, 2003). During the LGM, rivers discharged to the ocean a hundred kilometre or so beyond the present shoreline (Hübscher et al., 1998), and the adjacent interfluves had a thick unsaturated zone overlying fresh groundwater.

The rise in sea level between 18 and $6 \mathrm{Ka}$ was so rapid (averaging $>1 \mathrm{~cm}$ a year) that, combined with deposition of fine sediment, groundwater quality, and possibly even groundwater levels (cf. Kooi \& Groen, 2003), could not keep pace (establish a new equilibrium), trapping fresh or partially salinized groundwater offshore. Rapid sea level rise caused intrusion of estuarine water along the Ganges, Brahmaputra and Meghna rivers (Hoque, Hasan, \& Ravenscroft, 2003), with varying qualities of surface water invading adjacent aquifers at different times. Some of the elevated blocks would have developed into large islands before being inundated by fresh or brackish water (Hoque et al., 2014a). The complex interaction between the magnitude and timing of channel incision, subsidence and depositional-closure of groundwater discharges likely determined the variations in the deep aquifers discussed later.

The unconformable surfaces of the palaeosol-capped interfluvial blocks (McArthur et al., 2008; Hoque et al., 2012, 2014a) are fundamental divisors of the aquifer system, separating pre-LGM sediment from virtually unaltered post-LGM sediment. The Last Glacial Maximum Palaeosol (LGMP; Goodbred and Kuehl 2000a,b; McArthur et al., 2008) forms a barrier between the unweathered, often As-polluted, grey, post-LGM sediment above from almost-always As-safe, sediment below.

Deep aquifers are exploited for potable supply to depths of about $350 \mathrm{~m}$ by manually operated DTWs, which are the preferred small-scale supply where shallow tubewells (STWs) are affected by arsenic or salinity (Mosler et al., 2010; Johnston et al., 2013, Inauen, Hossain, Johnston, \& Mosler, 2013; Ravenscroft et al., 2014). Such DTWs have been installed in most of the southern, central and 
northeastern parts of the country but are concentrated towards the coast (Figure S1) where motorised DTWs are the main source of municipal and industrial supply. Deep tubewells are also a growing source of supply at Dhaka City, but are rarely used for irrigation except in West Bengal. The depth of abstraction tends to increase towards the coast (Figure S2) due to the increasing prevalence of saline water at intermediate depths. Jones (1985) and Khan (1991) both speculated on the existence of aquifers at depths of between 500 and $1500 \mathrm{~m}$ but these ideas have never been tested and are not considered further here.

\section{Data Sources and Processing}

We compiled a database of $\approx 24,000$ deep wells and piezometers that contains data on well depth, GPS location, piezometry, water quality and isotopic composition (Tables S1 to S4). The main water quality data are laboratory analyses of $\mathrm{Cl}, \mathrm{As}, \mathrm{Fe}$ and $\mathrm{Mn}$, which are widely measured as determinants of potability. The 20 data sets we compiled are described in SI-S1. The data come from surveys conducted between 1998 and 2014, for which, based on data measured over 13 years from the South-Central aquifer (Ravenscroft et al., 2013), we infer temporal stability of water quality over the period of measurement. The short screens $(3-6 \mathrm{~m})$ of most DTWs approximate point measurements of water quality, allowing the construction of As-depth profiles (Figure 2) and interpolation surfaces of probable $\mathrm{As}, \mathrm{Fe}$, and $\mathrm{Mn}$ (Figure 3) and $\mathrm{Cl}$ concentrations (Figure4) using the ArcView Spatial Analyst ${ }^{\circledR}$ software. Other maps were prepared using the QGIS software. However, some isolated pockets of arsenic contamination exceeding $50 \mu \mathrm{g} / \mathrm{L}$ may be due to incorrect reporting of well depth or construction defects (Aggarwal, Basu, \& Poreda, 2000; Ravenscroft et al., 2014; Stahl et al., 2014; Choudhury et al., 2016), and where such evidence was demonstrated, the record was omitted (SI-S3), but where no contradictory evidence was obtained, anomalous records were retained. The reasons for incorrect depths are often non-scientific, but the practical implication is that individual outliers should be treated with caution and our approach was to look for verification by identifying patterns and consistency between independent data sources. 
We also compiled a database on stable isotopes $\left({ }^{2} \mathrm{H}\right.$ and $\left.{ }^{18} \mathrm{O}\right)$ and radiocarbon measurements on deep groundwater as described in SI-S3 and summarised in Figures 5 and 6. Saline waters, with EC $>10,000 \mu \mathrm{S} / \mathrm{cm}$, are excluded from these graphs. Because of the uncertainties involved in model corrections to ${ }^{14} \mathrm{C}$ ages and inconsistencies in the data sets, we focus on the ${ }^{14} \mathrm{C}$ activities more than 'corrected' age estimates.

Information on piezometry, described in SI-S4, is compiled from dry-season measurements by the Department of Public Health Engineering (DPHE) in hand tubewells and hydrographs from piezometer nests constructed by the Bangladesh Water Development Board (BWDB, 2013), highlighted in Figure 7. Where water salinity varies significantly with depth, we applied the density corrections described by Lusczynski (1961) and Post, Kooi, \& Simmons (2007) for determining vertical hydraulic gradients. For all data, logical, mapping and graphing checks were conducted to identify and exclude probable reporting, analytical and transcription errors. The data are patchy in their distribution and of varying quality, facts which impair, but do not prevent, us from recognising eight geographically distinct multi-layered deep-aquifer units.

The definition of Aquifer Units was an iterative process based on the integration of established geological knowledge and hydrogeological understanding of the shallow aquifers with spatial patterns of hydrochemical and piezometric data. This was progressively validated or refined as new data sets were collected or published. GIS data on administrative boundaries and physiographic features used as backgrounds for maps were obtained from DPHE's GIS-database except for the palaeosol subcrop coverage which came from Hoque et al. (2014a).

\section{The Deep Aquifers}

The deep aquifer units we define (Figure 1, Table 1) have scales of the order of $100 \mathrm{~km}$ laterally and $200 \mathrm{~m}$ vertically. They have a degree of homogeneity that is valid at this scale but does not assume the correlation of individual beds or preclude internal layering (Figure S5). As such, they are geographical units comprising single or multiple aquifer horizons with a common character and 
with boundaries that are vertical at this scale. Lateral boundaries between aquifer units align with transitions in hydrochemical and other properties and also often with geological features. Northern and western boundaries follow respectively the Shillong Massif and the Hinge Zone, which marks the edge of the Indian Craton (Alam et al., 1990). The eastern boundary of the Sylhet Basin (SB), Southeastern (SE), and Chittagong Coast (CC) aquifers follows the front of the Indo-Burman fold belt. The boundary between the South-Central (SC), Central (Ce) and Madhupur (M) aquifers to the west and the SE and Sylhet Basin (SB) aquifers to the east coincides with the Lower Meghna river and a deep-seated thrust fault (Steckler et al., 2016). The inland projection of the Swatch of No Ground submarine canyon (Curray, Emmel, \& Moore, 2003) divides the SC and Southwest (SW) units. The boundaries of the Southwest and Western deep aquifers in Bangladesh shown in Figure 1 are extended across West Bengal towards the basin margin (Figure S3). Some workers in West Bengal refer to 'deeper groundwater', differentiating an unconfined to semi-confined Main Aquifer (the Sonar Bangla Aquifer of Mukherjee, Fryar, \& Howell, 2007a), $50 \mathrm{~m}$ to $>200 \mathrm{~m}$ thick, from socalled 'isolated aquifers' (Mukherjee, Fryar, \& Rowe, 2007b; Mukherjee \& Fryar, 2008; Mukherjee, Fryar, Scanlon, Bhattacharya, \& Bhattacharya, 2011).

The Sylhet Basin Deep Aquifer. Deep tubewells in this aquifer unit have a median depth of $173 \mathrm{~m}$ $(n=58)$ with $95 \%$ of wells less than $220 \mathrm{~m}$. This is the only deep aquifer that is extensively contaminated by As, which is most severe in the western part of Sunamganj District (Figure 1) where locally As exceeds $50 \mu \mathrm{g} / \mathrm{L}$ at all exploited depths (Figures 2 and 3), whilst concentrations of As are often $<50 \mu \mathrm{g} / \mathrm{L}$ in the south and east of the unit. The persistence of As at depth may arise from rapid subsidence (Johnson \& Alam, 1991; Ravenscroft et al., 2001, 2014; Chowdhury, Meharg, Deacon, Hossain, \& Norton, 2012) and slow circulation in a waterlogged basin with extreme rainfall (3 - 5 m annually) where abundant peat drives iron oxide reduction and Aspollution. 
Fe concentrations commonly exceed $1 \mathrm{mg} / \mathrm{L}$, but concentrations of $\mathrm{Mn}$ are mostly $<0.1 \mathrm{mg} / \mathrm{L}$. The few $\mathrm{Cl}$ concentrations available (IWM, 2015) are $<50 \mathrm{mg} / \mathrm{L}$ indicate an apparent absence of saline water. Five of the six available $\delta^{18} \mathrm{O}-\delta^{2} \mathrm{H}$ values plot above the Local Meteoric Water Line (LMWL; Figure 5) indicating the presence of a component of evaporating rainfall. Vertical hydraulic gradients are mainly upward (Figure 7), probably due to both the proximity of highland areas and compaction of peaty sediments.

The Chittagong Coast Deep Aquifer. Based on a very small sample $(n=18)$, it appears that most DTWs are completed close to the nominal minimum depth of $150 \mathrm{~m}$ but with a minority of wells $>300 \mathrm{~m}$ deep (Figure S2). This aquifer is the most heterogeneous, consistent with its elongate disposition, proximity to the Indo-Burman ranges and dissection by rivers emanating from the Hill Tracts to the east. Almost all DTWs produce groundwater with $<10 \mu \mathrm{g} / \mathrm{L} \mathrm{As}$, but Fe and Mn concentrations are variable (Figure 3). The majority of $\mathrm{Cl}$ concentrations are $<150 \mathrm{mg} / \mathrm{L}$ and most are $<50 \mathrm{mg} / \mathrm{L}$ (Figure 4); the few that exceed $600 \mathrm{mg} / \mathrm{L}$ are $>250 \mathrm{~m}$ deep. The few stable isotope measurements overlap the range of the SW, SC and SE aquifers discussed below. Radiocarbon measurements (Figure 5) indicate ages ranging from Recent $(>100 \% \mathrm{pmC}$ ) to the LGM (c. $6 \%$ $\mathrm{pmC})$.

Hydraulic gradients inferred from monitoring hand tubewells are mostly upward, reflecting the influence of adjoining highland areas, and support flowing artesian wells on offshore islands (e.g. Kutubdia). By contrast, most piezometer nests show consistently downward gradients with head differences of 0.3 to $10 \mathrm{~m}$, possibly because most are in urban centres and affected by municipal pumping (Figure 7).

Wood samples, dated at $38.6 \mathrm{Ka}$, from a depth of $130 \mathrm{~m}$ near Chittagong (Ravenscroft \& McArthur, 2004) imply deposition on a palaeo-land surface when sea level was about $90 \mathrm{~m}$ below its present level (and hence $40 \mathrm{~m}$ of post-depositional subsidence) that was associated with a palaeochannel of the Karnafuli River that extended beyond the present coastline from $>40 \mathrm{Ka}$ to 
around $10 \mathrm{Ka}$. This further implies a deep groundwater flux from the adjacent interfluves into the valley before the discharge was terminated by sediment deposition during the Holocene transgression.

The South-Central Deep Aquifer. This is the deepest aquifer unit with a median well depth of 265 $\mathrm{m}(n=3,880)$. The aquifer is the most isolated from the basin margins, and displays well-defined layering (DPHE-DANIDA, 2001; SI-S2). Brackish water is common above $200 \mathrm{~m}$ but below this depth water is fresh $(<50 \mathrm{mg} / \mathrm{L} \mathrm{Cl})$ with $\mathrm{As}<10 \mu \mathrm{g} / \mathrm{L}, \mathrm{Fe}<1$ and often $<0.3 \mathrm{mg} / \mathrm{L}$ and $\mathrm{Mn}<0.1$ $\mathrm{mg} / \mathrm{L}$. The SC groundwater is isotopically heavier (mostly $\delta^{18} \mathrm{O}-1.8$ to $-3.3 \%$ ) than in the upgradient Central Deep Aquifer (mostly $\delta^{18} \mathrm{O}-3.1$ to $-6.5 \%$; Figures 5 and 6), with little overlap, and has the oldest mean ${ }^{14} \mathrm{C}$ age of $>15 \mathrm{Ka}$. Of all the aquifer units, the SC Deep Aquifer displays the most compact and extreme grouping in terms of the ${ }^{18} \mathrm{O}-{ }^{2} \mathrm{H},{ }^{18} \mathrm{O}-{ }^{14} \mathrm{C}$, and ${ }^{18} \mathrm{O}$ and ${ }^{14} \mathrm{C}$ versus depth plots.

A few tens of water samples with full analyses allow comparison of the composition of SC groundwater in Barisal with the adjacent SE aquifer at Lakshmipur (Figure 8). Concentrations of $\mathrm{HCO}_{3}$ and $\mathrm{Na} / \mathrm{Ca}$ ratios are higher than in the SE aquifer. Elevated $\mathrm{Na}$ and $\mathrm{B}$ (Ravenscroft \& McArthur, 2004) are attributed to ion exchange following incomplete flushing of saline water emplaced long before the LGM, possibly during the high stand around $125 \mathrm{Ka}$. The high concentrations of $\mathrm{Na}$ and $\mathrm{B}$ imply that through-flow has been restricted for tens of thousands of years; an isolation that probably accounts for the relatively tight range of chemical and isotopic composition.

Nine of eleven piezometer nests show downward gradients with head differences of $2-4 \mathrm{~m}$ all year round (Figure 7), suggesting the aquifer has been affected by sustained pumping since the 1970 's, although dry season water levels remain within suction limits almost everywhere (Figure S7). Anomalous upward gradients in central Bhola Island, close to a commercial gas field, coincide with methane-rich artesian flows that have sustained domestic cooking stoves for several 
decades and are warmer and slightly more saline than other DTWs on Bhola (Figure S10). Artesian flow may result from buoyant rise of warm, methane-saturated water.

The Southeast Deep Aquifer. Wells in the SE Deep Aquifer have a median depth of $235 \mathrm{~m}(n=$ 10,855), distinctly less than in the adjacent SC aquifer to the west (Figure 2) and includes a number of well-researched sites in its southern, central and northern parts (DPHE, 2001; von Brömssen et al., 2014; Mihajlov et al., 2016, and references therein). The SE aquifer is characterised by several $\mathrm{mg} / \mathrm{L}$ amounts of $\mathrm{Fe}$, with concentrations often $>5 \mathrm{mg} / \mathrm{L}$, and $\mathrm{Mn}$ which frequently exceeds 0.1 and locally $0.4 \mathrm{mg} / \mathrm{L}$. Concentrations of As are, nevertheless, mostly $<10 \mu \mathrm{g} / \mathrm{L}$ in contrast to shallow aquifers in which high-Fe groundwater is rarely As-safe (DPHE, 1999; von Brömssen et al., 2014; Mihajlov et al., 2016). The median $\mathrm{Cl}$ concentration is $100 \mathrm{mg} / \mathrm{L}$ with concentrations of $<50 \mathrm{mg} / \mathrm{L}$ common. A NNW-SSE alignment of pockets of elevated Cl may delineate a deep LGM palaeochannel later occupied by an estuary and now associated with brackish and organic-rich (taste and odour issues) water (Hoque et al., 2003; Ravenscroft et al., 2014; UNICEF-VERC unpub.).

Mangrove fragments dated at $35.8 \mathrm{Ka}$ at a depth of $95 \mathrm{~m}$ in Noakhali (Ravenscroft \& McArthur, 2004) identify proximity to a former shoreline at about $80 \mathrm{~m}$ below modern sea level and indicates that much of the SE aquifer had a terrestrial cover then and through to the LGM, hence water percolating through the perched mangrove deposits during the LGM may have driven Fe and Mn reduction in the deep aquifer below.

Bicarbonate concentrations are low relative to groundwaters from the SC aquifer (Figure 8) but are similar to groundwaters from the Madhupur aquifer. The depletion in $\mathrm{B}$ and $\mathrm{Na}$ relative to $\mathrm{Cl}$ is attributed to percolation of connate water with a marine influence during the post-LGM transgression (Ravenscroft \& McArthur, 2004). Groundwater from the SE aquifer has the widest and most continuous range of stable isotope composition and radiocarbon activities; and no practical isotopic, chemical or geological basis for subdividing the unit was identified. The majority of $\delta^{18} \mathrm{O}$ measurements range from -1.5 to $-4 \%$, some with strong evaporative effects, but with a 
tail of values down to $-6 \%$ o that plot close to the LMWL. Samples heavier than about $-3 \%$ are dominantly drawn from below 250m, and vice versa (Figure 6). Groundwater ages range from late Holocene $(>80 \% \mathrm{pmC}$ ) to around $18 \mathrm{Ka}$ or older (Figure 5) with an apparent bias towards values of 10 to $30 \mathrm{pmC}$ (terminal Pleistocene to mid-Holocene, $15-5 \mathrm{Ka}$ ): groundwater with this composition has penetrated several hundred metres into Pleistocene strata, implying that groundwater circulated relatively freely to the ocean during the LGM before it became progressively restricted during the subsequent transgression. The trend of ${ }^{14} \mathrm{C}$ activity with depth is not linear (Figure $5 \mathrm{c}$ ) but fall within a bounding envelope of $0.4 \mathrm{pmC} / \mathrm{m}$, suggesting that the process was spatially variable.

Along its northwestern boundary, the SE aquifer has an inferred erosional contact with the Madhupur Unit, as observed between Dhaka City and Araihazar (Figure 1) where the Madhupur Clay dips beneath the Old Brahmaputra floodplain (Hoque, Hoque, \& Ahmed, 2007; Knappett et al., 2016). Here, water in the SE aquifer has a similar stable isotopic composition to the upper part of the Madhupur aquifer but is clearly distinguished by higher $\mathrm{Cl}$ concentrations resulting from infiltration through post-LGM estuarine sediments as opposed to recharge on the Madhupur Tract.

In the south, deep piezometric levels are generally within $4 \mathrm{~m}$ of ground level (Figure 7) but further inland levels regularly fall below suction limits $($ c. $7.5 \mathrm{~m})$, even though significant deep abstraction did not begin until after 2000. In the north, seasonally divergent hydrographs are the norm but further south downward gradients dominate (DPHE, 2001; BWDB, 2013; von Brömssen et al., 2014).

Although trends of increasing well depth and groundwater age from north to south are statistically insignificant $(r=0.23)$, that of increasing $\delta^{18} \mathrm{O}$ enrichment is much stronger $(r=0.66)$. Combined with the piezometric response, this suggests that the aquifer is more confined and/or hydraulically enclosed in the south. 
The Southwest Deep Aquifer. In Bangladesh, this aquifer has a similar range of well depths (median $235 \mathrm{~m}, n=696$ ) to the SE aquifer (Figure S2) and has been abstracted and studied intensively at Khulna, where its sedimentological heterogeneity at the scale of $10^{3} \mathrm{~m}$ is shown by a change from a continuous sandy pre- and post-LGM palaeochannel sequence to a cover of $200 \mathrm{~m}$ of clay (Rus, 1985; BRGM, 2005), demonstrating the importance of sub-regional vertical and lateral conduits and barriers to groundwater flow. The unit is inferred to continue westwards across West Bengal to the edge of the basin.

The properties of the Bangladesh part of the SW aquifer are intermediate between SC and SE aquifers: concentrations of As are mostly $<10 \mu \mathrm{g} / \mathrm{L}$ and those of Mn generally $<0.1 \mathrm{mg} / \mathrm{L}$. Fe concentrations are low in the south and west but often exceed $1 \mathrm{mg} / \mathrm{L}$ in the north and east. Concentrations of $\mathrm{Cl}$ (median $365 \mathrm{mg} / \mathrm{L}$ ) are higher than in other aquifers, with $29 \%$ of groundwaters exceeding $600 \mathrm{mg} / \mathrm{L}$ and only $6 \%<50 \mathrm{mg} / \mathrm{L}$. There is a wide range of stable isotope composition $\left(\delta^{18} \mathrm{O}\right.$ of -2 to $-5.5 \%$ ) but with a suggestion that the data fall into heavier and lighter groups with a gap at about $\delta^{18} \mathrm{O}-4 \%$; however, there is insufficient evidence to divide the unit. The available radiocarbon activities indicate recharge between the LGM and the early-Holocene, however, there are no age determinations from the isotopically lighter waters.

Despite long-term abstraction (Ravenscroft et al., 2009), water levels generally remain within suction limits (Figure S7). Hydrographs show continuously downward gradients $(2-4 \mathrm{~m}$ head difference) near Khulna City (probably in response to decades of deep municipal pumping) but are coincident or seasonally divergent further west (Figure 7). Measurements from five IWM-DPHE piezometer nests southwest of Khulna City where both shallow and deep aquifers often contain brackish water were adjusted for density to give correct vertical head gradients (SI-S4). Density corrected hydrographs (Figure S8) contain unlagged, parallel trends suggesting that mechanical loading, as opposed to recharge, is responsible for the deep water-level fluctuations (cf. Burgess et al., 2017). At the northernmost site, where all groundwater is fresh, the deep piezometric surface is below sea level and the gradient is downward. However, at the other sites where the deep 
piezometers are screened in brackish (and unpumped) horizons, gradients are either upward or seasonally variable. The association between density-corrected freshwater head and EC (Figure S9) suggests the presence of 'dead-end' or 'isolated' aquifers that were not flushed during the LGM, and that the downward gradients recorded further inland have been induced by pumping.

By contrast, the West Bengal part of the SW Deep Aquifer has been abstracted both for municipal (including at Kolkata) and irrigation purposes since the 1970s, creating stronger downward fluxes (McArthur et al., 2008). Mukherjee et al. (2007a) indicate that, over large areas, dominantly sandy sequences extend from the surface aquitard to $200-250 \mathrm{~m}$, before dividing into multiple thinner aquifer horizons towards the coast; they also suggest that the shallow and deeper (below 150m) parts of the Sonar Bangla (or Main) Aquifer are well connected vertically, a conclusion that is open to question because it does not recognise the LGMP as a barrier to vertical flow and divisor of water quality except where incised palaeochannels provide preferential pathways to the deep aquifer (McArthur et al., 2008; Hoque et al., 2012). .

The isotopically lighter water is concentrated between 150 and $200 \mathrm{~m} \mathrm{bgl}$ and, as with the few public water supply wells that fractionally exceed $50 \mu \mathrm{g} / \mathrm{L} \mathrm{As}$, has been attributed to sustained deep irrigation-pumping (Mukherjee et al., 2011). However, it is important to distinguish what may be local effects around large diameter, and perhaps imperfectly sealed, wells from bulk contamination of the aquifer. Dissolved methane concentrations of up to $26 \mathrm{mg} / \mathrm{L}$ at depths of 150-280 $\mathrm{m}$ have been reported from the north of the unit (Mukherjee \& Fryar, 2008). The 'isolated' aquifers contain somewhat heavier water $\left(\delta^{18} \mathrm{O}-3.2\right.$ to $-4.2 \%$ ) which is also slightly brackish (mean $1,622 \mathrm{mg} / \mathrm{L}$ $\mathrm{Cl}$ ). Concentrations of $\mathrm{Fe}$ are mostly $<1 \mathrm{mg} / \mathrm{L}$ and $\mathrm{Mn}$ concentrations are generally $<0.01 \mathrm{mg} / \mathrm{L}$. McArthur, Ghosal, Sikdar, \& Ball (2016) have inferred that low level As contamination $(\leq 15 \mathrm{ppb})$ below some palaeochannels was generated in-situ (i.e. not drawn down under the influence of pumping). 
The Central Deep Aquifer. The Central Aquifer has a median well depth of $225 \mathrm{~m}(n=377)$ and lies beneath the Holocene floodplains of the Ganges-Padma and Brahmaputra-Jamuna rivers. The sediments are mainly grey but brown oxidised sediments are encountered at depths of 135 to $240 \mathrm{~m}$, well below the base of the LGM transgressive sequence (DPHE, 2001; De Silva, Wightman, \& Kamruzzaman, 2010; Hug et al., 2011). Although As concentrations are generally low, pockets with $>50 \mu \mathrm{g} / \mathrm{L}$ align with a deeply-incised palaeochannel (Hoque et al., 2014a; Wilson \& Goodbred, 2015) of presumed LGM age. Fe is generally $>1 \mathrm{mg} / \mathrm{L}$, and Mn commonly exceeds 0.1 and occasionally $0.4 \mathrm{mg} / \mathrm{L}$. Concentrations of $\mathrm{Cl}$ vary relatively little, with $91 \%$ of samples between 150 and $600 \mathrm{mg} / \mathrm{L}$. The groundwater is isotopically lighter $\left(\delta^{18} \mathrm{O}-3.3\right.$ to $-6.6 \%$ ) than in the SW, SW, $\mathrm{SE}$ and $\mathrm{CC}$ aquifers, and is similar in isotopic composition to water in the main rivers. Groundwater in this aquifer is increasingly enriched in $\delta^{18} \mathrm{O}$ with increasing depth (Figure 6) and these isotopic compositions overlap minimally with those groundwaters in the down-gradient SC Aquifer. The water is young; ${ }^{14} \mathrm{C}$ activities of $49-85 \mathrm{pmC}$ suggest recharge during the mid- to late Holocene, consistent with chemical data that suggest Holocene estuarine waters penetrated more than a hundred metres into Pleistocene strata, and the salinity locally exceeds what is acceptable for long term potable use (Hug et al., 2011). In the late dry season (March-April), water levels fall to 5 - 9 $\mathrm{m}$ bgl, often exceeding the suction limits of hand pumps. Hydraulic gradients are mostly neutral or weakly downward; and the two piezometer nests show coincident hydrograph responses (Figure 7; DPHE, 2001; BWDB, 2013).

The Western Deep Aquifer. This aquifer unit is defined from limited information (DPHE-JICA, 2002, 2008; Shibasaki et al., 2007) and is tentatively extended across adjoining areas of West Bengal. Productive horizons occur between 150 and $380 \mathrm{~m}$. The sequence contains, and is distinguished from the Central and SW aquifers by, thick but discontinuous gravels between 100 and $200 \mathrm{~m}$. These gravels must significantly pre-date the LGM because they are too deep to have been deposited during the LGM and underlie extensive palaeosols. Shibasaki et al. (2007) divide the 
sequence into five formations, of which their $\mathrm{C}$ formation, or middle aquifer (at depths of 90 to 220 m), contains highly permeable sandy layers with abundant pebble-sized gravel, but also many intercalated clay layers that confer high vertical anisotropy. The underlying D formation (at depths of 160 to $240 \mathrm{~m}$ ) comprises sands and silt that become coarser grained and more permeable with depth. The LGM palaeosol is present at depths of a few tens of metres across much of the area but is incised by deep palaeochannels which would have directed recharge to deeper aquifers (Hoque et al., 2014a).

Concentrations of As are mostly $<50 \mu \mathrm{g} / \mathrm{L}$ and $\mathrm{Mn}<0.4 \mathrm{mg} / \mathrm{L}$, although Fe often exceeds $1 \mathrm{mg} / \mathrm{L}$. Few $\mathrm{Cl}$ determinations are available, but in Chuadanga, Jhenaidah and Jessore towns all were $<50 \mathrm{mg} / \mathrm{L}$ (DPHE-JICA, 2002). In Jessore District, there are alignments (presumed palaeochannels) of distinctive water quality at depth of $170-240 \mathrm{~m}$, where $8 \%$ of samples contained $>50 \mu \mathrm{g} / \mathrm{L} \mathrm{As}$, and 25\% contained $>1 \mathrm{mg} / \mathrm{L} \mathrm{Fe}$ and $0.4 \mathrm{mg} / \mathrm{L} \mathrm{Mn}$ (JICA-UNICEF, 2005). The stable isotope analyses are consistently light $\left(\delta^{18} \mathrm{O}\right.$ mostly $\left.<-4.0 \%\right)$, similar to the Central aquifer and overlap the range of the SW aquifer (Figures 5 and 6). In West Bengal, deep groundwater ranges widely from $\delta^{18} \mathrm{O}-2.8$ to $-6 \%$, but the majority of water samples are light $\left(\delta^{18} \mathrm{O}<-3.8 \%\right)$. Dissolved methane concentrations of up to $1,224 \mathrm{mg} / \mathrm{L}$ were measured in two wells in isolated aquifers at depths of 220-240m (Mukherjee \& Fryar, 2008).

Where the Ganges debouches from the Rajmahal Hills into West Bengal, there is significant heterogeneity where palaeosol-capped palaeointerfluves divide palaeochannels. Much of the West Bengal part of the Western Aquifer comprises thin layers below 200m with thick clay cover (the Murshidabad Aquitard of Mukherjee et al. 2007a) with a heavier stable isotope composition. The thick and extensive gravels documented in Bangladesh are largely absent in West Bengal, and the boundary between the SW and Western aquifers may require revision as more data become available.

In Bangladesh, deep piezometric levels were 4.5 to $6.5 \mathrm{~m}$ bgl in 2001 (DPHE-JICA, 2002) but now widely exceed suction limits in the dry season. The hydrograph responses transition from 
weak ( $0.5 \mathrm{~m}$ difference) but consistently downward in the south, through seasonally divergent and coincident responses in the central parts, to a small upward gradient ( $0.4 \mathrm{~m}$ difference) in the northwest (Chuadanga).

The Madhupur Deep Aquifer. This aquifer unit corresponds to the Madhupur Tract landform and its subsurface expression in the Madhupur Clay subcrop which overlies and confines the Dupi Tila Formation (Alam et al., 1990). The unit is well defined beneath Dhaka City, where it is divided into Upper and Lower units by clayey horizons between 130 and $210 \mathrm{~m}$ (Hoque et al., 2007). It is also identified in a few municipal wells across the Madhupur Tract with a maximum proven depth of $217 \mathrm{~m}$ (IWM, 2015). The Madhupur Clay outcrop has not been submerged for at least $110 \mathrm{Ka}$ (Whitney, Pavich, Huq, \& Alam, 1999), accounting for the thorough flushing of the aquifer below it.

Municipal abstraction at Dhaka has progressively shifted to greater depth as the water table has declined to more $50 \mathrm{~m}$ bgl (Hoque, McArthur, Sikdar, Marshall, \& Molla, 2014b; Knappett et al., 2016). Wells with a median depth of $237 \mathrm{~m}$ show a low and narrow range of $\mathrm{Cl}$ concentrations (median $10 \mathrm{mg} / \mathrm{L}$ ) and As $(<4 \mu \mathrm{g} / \mathrm{L})$, with only very rare exceedance of the 1.0 and $0.4 \mathrm{mg} / \mathrm{L}$ thresholds for Fe and Mn (Hoque et al., 2014b). The limited data from outside Dhaka indicate that As, Fe and Mn concentrations are very low there too (IWM, 2015).

Long-screened wells at the top of the deep aquifer (well depths of $150-180 \mathrm{~m}$ ) produce isotopically light water $\left(\delta^{18} \mathrm{O}-4.6\right.$ to $-5.5 \%$; Darling, Burgess, \& Hasan, 2002) with the same isotopic composition as the shallow aquifer, whereas deeper wells $(225-335 \mathrm{~m})$ produce a distinct (Figure 6) and heavier 'pristine' water $\left(\delta^{18} \mathrm{O}-3.1\right.$ to $-4.0 \%$; Hoque et al., 2014b), similar to the light-end of the range in the SC and the heavier waters in the SE and SW aquifers. The nature of this difference is demonstrated by $\mathrm{Cl} / \mathrm{Br}$ values at the top of the aquifer which indicate contributions from river infiltration and leaking septage. By contrast, heavier water below $200 \mathrm{~m}$ has no anthropogenic signature (Hoque et al., 2014b). Groundwater in the Lower Dupi Tila aquifer has a 
more homogenous composition and higher mean $\mathrm{HCO}_{3}$ content. No radiocarbon measurements are available from Dhaka, however, the ${ }^{18} \mathrm{O}$ content suggests an LGM origin.

\section{DISCUSSION}

\subsection{Continuity and Connectivity of the Deep Aquifers}

The hydrogeological nature of many of the boundaries of the deep aquifers is not known. As opposed to a lithological-geostatistical model with no internal boundaries (Michael \& Voss, 2009b), we mapped units based on their hydrochemical, isotopic and piezometric characteristics supported by inferences regarding their sedimentary and palaeo-hydrological settings. Future investigations may more fully explain and sub-divide the deep aquifer units in terms of superimposed sedimentary responses to sea-level variation over the past several glacial cycles in a manner analogous to the differentiation of shallow aquifers into palaeointerfluvial and palaeochannel aquifers (DPHE, 1999; McArthur et al., 2008) during the last glacial cycle. The two approaches may eventually be integrated but neither alone is sufficient to capture the multiple scales of heterogeneity observed: $10^{1}-10^{2} \mathrm{~m}$ (McArthur et al., 2004, 2008; van Geen et al., 2003), 103 - 10 $\mathrm{m}$ (Hoque et al., 2012, 2014a) and $10^{4}-10^{5} \mathrm{~m}$ (this study).

Although our deep aquifer units lack the rigid boundaries of lithostratigraphic classifications, we contend that, in a basin as large as the Bengal Basin, they are no less useful for that. They provide a conceptual framework that could not be achieved by traditional means; and are comparable to the WFD definition of a 'groundwater body' that can be used for practical water resources management (UKTAG, 2012). These 'fluid boundaries' may change from the reference (pre-development) state, such as happens at Dhaka City where isotopically light water is being drawn down into the upper part (150-180 m) of the Madhupur Aquifer (Hoque et al., 2014b). Elsewhere migration will be slower but the stable isotopic and $\mathrm{Cl} / \mathrm{Br}$ differences used at Dhaka offer potential for tracking changes, even where no baseline is defined. 
By adopting the local convention of depth $>150 \mathrm{~m}$ for deep aquifer units, we have not defined their upper boundaries hydrogeologically. This was necessitated by lack of information on the PlioPleistocene stratigraphy and the extent and properties of pre-LGM aquitards. Although partly based on a presumed relationship to the lowest LGM sea-level of around $120 \mathrm{~m}$ bsl, the $150 \mathrm{~m}$ criterion was fundamentally an empirical guide to arsenic-avoidance at national level (DPHE, 1999; Ravenscroft et al., 2014). Although As-safe depths may be much less (e.g. McArthur et al 2008; Hoque et al., 2014a; van Geen et al., 2016), the $150 \mathrm{~m}$ criterion remains useful for structuring discussions; it should be progressively superseded with aquifer-specific hydrogeological criteria, such as between the Upper and Lower Dupi Tila Aquifer at Dhaka City, that include information on the vertical continuity and recharge pathways between shallow and deep aquifers and the distribution of the LGMP and older palaeosols.

The aquifer units we define all have varying degrees of internal layering. Assessing the significance of this is beyond the present scope, and the availability and spatial definition, of present information on water chemistry and piezometry. Although not apparent now, it is to be expected that divergent piezometric trends will be observed with increased development.

\subsection{Offshore Extensions}

The offshore extension and natural discharge mechanisms of the coastal deep aquifers are largely unknown. In other mega-deltas, rising sea levels trapped fresh water far offshore (Kooi \& Groen, 2003; Post et al., 2013) and, since the Bay of Bengal lay some $100 \mathrm{~km}$ to the south during the LGM (Hübscher \& Spieß, 2005), it is likely that extensive fresh or brackish water reserves presently occur offshore of at least some of the deep aquifers, a notion supported by artesian flows on offshore islands and inferences from ancient coastlines (Wiedicke, Kudraß \& Hübscher, 1999). Seismic evidence suggests the SC aquifer, and probably also the SE and SW aquifers, extends more than a hundred kilometres offshore, although the water quality is unknown [SI-S5; Figure S11]. 
Gradients of $\mathrm{B}, \mathrm{Na}$ and $\mathrm{Cl}$ suggest the $\mathrm{SC}$ aquifer once discharged westwards towards a former extension of the Swatch of No Ground (Ravenscroft \& McArthur, 2004; Figure S12). The preservation of these gradients in fresh groundwater dating from at least the LGM points to progressively restricted continuity of the SC Deep Aquifer with the ocean during the late Pleistocene.

\subsection{Piezometric Responses to Development}

The responses of paired hydrographs in deep and shallow aquifers show a progression in style down-basin: (1) in the north, deep and shallow hydrographs are more or less coincident throughout the year; (2) further south, the hydrographs are seasonally divergent, with deep levels falling below shallow levels in the dry season; and (3) approaching the coast, there are permanently downward, and near constant, hydraulic gradients in the SC, SW and CC aquifers [Figure 7; SI-S4]. The southerly progression of responses appears to be related to the inter-annual rate of drawdown in the deep aquifers. Drawdown of the pre-development piezometric surface is greatest inland but the separation between shallow and deep water-levels becomes more permanent toward the coast (Figure 7). Near the coast, where DTWs have been used longest and groundwater is older, dynamic water levels rarely fall below suction limits. In the Central aquifer and much of the SE aquifer, where water levels fall to 6 to $12 \mathrm{~m} \mathrm{bgl} \mathrm{(Figure} \mathrm{S7)} \mathrm{rendering} \mathrm{suction} \mathrm{pumps} \mathrm{inoperable,} \mathrm{the}$ aquifers have been deeply penetrated by Holocene groundwater, suggesting greater vertical continuity than at the coast.

The perennial downward gradients approaching the coast and the greater drawdown of the piezometric surface inland were not expected based on classical flow-net analyses of basinal flow (e.g. Toth, 1970). Possible explanations for downward gradients are (a) deep submarine groundwater discharge; (b) natural gas abstraction and (c) geological under-pressure due to incomplete equilibration to post-LGM base level change [SI-S4]. Submarine discharge has been advocated to explain marine geochemical anomalies (Moore, 1997; Basu et al., 2001) but is 
inconsistent with the inland gradients in the SW Aquifer and other evidence [Harvey, 2002; SI-S4]. Gas abstraction could be of only local significance because there are few commercial gas fields in the area. However, the third alternative, incomplete equilibration, is possible [SI-S4]. Since deep abstraction for irrigation is minimal (e.g. BADC, 2015), greater unit drawdowns in deep aquifers than in overlying shallow aquifers are readily attributed to the small storage coefficients of confined aquifers. However, the greater drawdowns in the less confined inland deep aquifers, compared to their coastal equivalents, cannot be explained by the distribution of DTWs used for potable supply alone [Figure S1] and calls for an additional explanation. One possibility is that deep water-levels near the coast are maintained in dynamic equilibrium by release from confined storage and/or compaction-induced flow offshore (cf. Kooi, 1999). A second, and not mutually exclusive, possibility stems from the probability that both deep and shallow abstraction are partially maintained by leakage from intervening aquitards. Near the coast, flow is predominantly downward whereas inland, long-term irrigation abstraction from shallow aquifers may have resulted in dominantly upward leakage such that downward leakage from aquitards at intermediate depth is less able to balance abstraction from the deep aquifer. To resolve such issues, monitoring of piezometric levels in intervening aquitards is required. Such leakage might induce land subsidence.

\subsection{Groundwater Recharge through the Late Quaternary}

The disposition of isotopic characteristics in the deep aquifers offers insights into dominant, active and dormant flow paths and thereby how they may respond to development. Our classification of deep aquifer units allows recognition of five distinct periods of groundwater recharge in the Bengal Basin between the LGM and the present:

Period 1: 30 - $15 \mathrm{Ka}$. No groundwater has been dated at more than $25 \mathrm{Ka}$, but groundwaters dated at more than $17 \mathrm{Ka}$ or containing less than about $12 \mathrm{pmC}$ are believed to have been recharged during the LGM and some could be at least as old as $30 \mathrm{Ka}$. At this time, sea levels and river incision were at their lowest, the shoreline was displaced $100-150 \mathrm{~km}$ to the south, monsoonal 
circulation was greatly reduced, and the main river channels operated as a 'conveyor belt' to the marine delta (Blum \& Törnqvist, 2000), resulting in increased sediment accumulation offshore before $17 \mathrm{Ka}$ (Contreras-Rosales et al., 2014). Groundwaters from Period 1 characterise the SC aquifer, much of the SW aquifer, the deeper part of the Madhupur aquifer and some samples from the SE and Chittagong Coast aquifers. This water is the most enriched in heavy isotopes $\left(\delta^{18} \mathrm{O}-1.5\right.$ to $-3.5 \%$ ), possibly derived from a local precipitation system rather than Himalayan melt water. Recharge occurred mainly along the palaeovalleys with little recharge occurring through the intensely weathered soils of the interfluves but sufficient to oxidise the underlying sands. Period 1 groundwater is low in As, Fe, $\mathrm{Mn}$ and $\mathrm{Cl}$.

Period 2: 15 - $10 \mathrm{Ka}$. A few groundwater samples from the SE, SC and SW aquifers, with ${ }^{14} \mathrm{C}$ activities of $>12$ to about $30 \mathrm{pmC}$ have been dated at between 10 and $15 \mathrm{Ka}$. Period 2 was marked by a combination of continued conveyor-belt system with vertical aggradation along the main channels (Hübscher et al., 1998; Hübscher \& Spieß, 2005) prior to overtopping of the interfluves or re-establishment of monsoonal circulation. These waters are lighter $\left(\delta^{18} \mathrm{O}-3\right.$ to $\left.-4 \%\right)$ than those from Period 1 but similar to modern shallow groundwater as measured in dug wells by Dray (1982). The inverse correlation between ${ }^{14} \mathrm{C}$ activity and $\delta^{18} \mathrm{O}$ from Period 1 to Period 3 suggests a progressive shift from local rainfall to riverine melt water and/or higher altitude rainfall. This water typically contains several milligrams per litre of iron, and higher $\mathrm{Cl}$ than in older waters.

Period 3: 10 - 5 Ka. The early Holocene involved the transition to a more modern type of environment with re-establishment of monsoonal circulation, aggradation in the main channels followed by flooding of the interfluves and progradation of deltas into the newly created paludal basins (Goodbred \& Kuehl 2000a,b; Goodbred, 2003; McArthur et al., 2004). This flooding comprised both freshwater and marine events (Hoque et al., 2003). Period 3 groundwaters comprise a small group of samples that is lighter $\left(\delta^{18} \mathrm{O}-4\right.$ to $-5 \%$ ) than in Period 2 and found at depths of 50 to $300 \mathrm{~m}$, mainly beneath the Meghna floodplains. They have high to very high iron concentrations and slightly elevated $\mathrm{Cl}$ concentrations. 
Period 4: 5 - $0.05 \mathrm{Ka}$. The later Holocene (excluding the Anthropocene) built up the present land surface along the main channels and across the interfluves, burying early Holocene peat basins beneath silty or sandy deposits (Allison et al., 2003). These groundwaters lack tritium but contain more than about $50 \mathrm{pmC}$ and are mostly recorded from the SE, Central and Western aquifers. Groundwater recharged in Period 4 is lighter $\left(\delta^{18} \mathrm{O}-5\right.$ to $-7 \%$ ) than older waters and overlaps the composition of modern rivers and rainfall (Mukherjee et al., 2007b; Sengupta et al., 2006). This differs from the Anthropocene in which recharge is derived dominantly from local rainfall (MPO, 1987; WARPO, 2001), a change partially attributed to stabilisation of the land surface and restriction of riverine flooding by agricultural activity (Brammer, 2012).

Period 5: 50 - 0 a. These modern waters contain 'bomb' tritium and/or more than $100 \mathrm{pmC}$. They are not significant in deep aquifers and any such detection in a deep well is a potential indication of a leaking well casing.

Although water recharged in Period 4 and Period 5 is predominant in the shallow aquifers, groundwater in deep aquifers is dominated by recharge in Periods 1 and 3. This bimodal distribution characterises two dominant modes of occurrence; the first in hydraulically-enclosed situations that resisted flushing during, and in the early-post, LGM times, and the second the result of infiltration along, and rapid throughflow from, the aggrading LGM palaeochannels before deep circulation was curtailed by the reduced hydraulic gradients consequent on sea-level rise and fine-sediment accumulation from mid-Holocene times.

\section{Uncertainty and research needs}

There are many gaps and uncertainties in our definition of deep aquifer units, and probably many surprises yet to be discovered. Uncertainties derive from two main sources: the absence of information and erroneous or misleading information. Anomalous water quality and isotopic data warrant selective investigation of the depth and integrity of wells, and the collection and analysis of that water. 'True' three-dimensional aquifer boundaries, resulting from tectono-sedimentary, 
climatic and weathering processes, may be sharp or transitional and not the smooth lines drawn on national-scale maps. The adequacy of our units should be judged by their utility, and progressively refined. In all cases, understanding can be improved by further geological investigations. With these provisos, filling the gaps in knowledge requires more $\mathrm{Cl}$ and isotopic analyses from the Sylhet Basin and Chittagong Coast, plus carbon isotope analyses from the Western and Madhupur aquifers. In the SC Aquifer there is scope to apply other isotopic techniques, such as ${ }^{36} \mathrm{Cl}$, after verifying the integrity of wells. The definition of all boundaries could be improved, but there is particular attention should be given to the boundary between the W and SW aquifers. Knowledge of the coastal extension of deep aquifers, and areas where deep drilling is constrained by 'impenetrable' gravels, could easily be improved by routine reporting of unsuccessful deep wells. The BWDB (2013) network of piezometer nests in the coastal zone should be extended to the Central, Sylhet, Madhupur and Western aquifers. Dry season piezometric monitoring of operational water wells should be increased to a quarterly or monthly frequency and combined with water quality monitoring.

\section{Implications for water supply and water resource management}

The eight deep aquifer units identified here demolish the myth of the monolithic 'deep aquifer' and provide a framework for planning and managing sustainable abstraction of deep groundwater. Each unit has different potential in terms of water quality, depth, piezometric response and cost, as well as different shallow groundwater and surface water alternatives. Although deep groundwater is potable with respect to health almost everywhere outside the Sylhet Basin, high Fe concentrations often render the water aesthetically objectionable for long-term supply. Only in the SC, Madhupur and, to a lesser extent, SW aquifers is Fe consistently acceptable $(<1 \mathrm{mg} / \mathrm{L})$ or $\operatorname{good}(<0.3 \mathrm{mg} / \mathrm{L})$. Tolerance of high Fe varies inter alia between generations (i.e. rising expectations), and while Fe concentrations of $\leq 3 \mathrm{mg} / \mathrm{L}$ may be tolerated in hand-pumped wells (PSU, 2011), piped systems will require treatment from the outset. Where removal of both iron and arsenic is required, shallow 
groundwater may be easier to treat due to higher Fe:As ratios (Ravenscroft et al., 2009). Deep piezometric levels will increasingly fall below suction limits in the SE, Central, Western and perhaps other aquifers; so new DTWs should be equipped with force mode pumps to prevent obsolescence, and studies undertaken to predict declining piezometric and/or water quality trends.

The deep aquifer units show broad similarities to, but also important differences from, the surface-water based Extended Hydrological Regions of WARPO (2001). The groundwater units are of similar or smaller scale; some boundaries coincide but others reflect a fundamental partitioning of the subsurface. Similar units should be defined for shallow aquifers to support integrated management of deep and shallow groundwater and surface water.

Various authors have opined on the likely sustainability, or otherwise, of deep groundwater abstraction (e.g. DPHE, 1999; Shibasaki et al., 2007; Michael \& Voss, 2008; Burgess et al., 2010; Radloff et al., 2011; Ravenscroft et al., 2013; Mihajlov et al., 2016). A detailed consideration of sustainability is beyond the present scope but our classification provides a framework for assessment and offers some cautionary comments. First, sustainability should be assessed specifically in relation to aquifer units, or smaller scales, and not at the basin level. Second, deep aquifers preserving the heavier water dating from Period 1 may prove to have greater hydraulic protection. Third, numerical models, which are powerful tools for assessing the sustainability of deep groundwater abstraction, will require refinement to incorporate the improved conceptual understanding revealed here. The downward gradients approaching the coast are not captured in existing simulations and may require modification of the coastal boundary conditions. Also, the use of ${ }^{14} \mathrm{C}$ ages and steady-state particle-tracking techniques for calibration assumes that the aquifer geometry and hydro-climatic conditions were constant over the period of the simulation. An alternative interpretation that groundwater is essentially connate (i.e. groundwater age falling on the global sea level curve) fit a few data points from the SE Aquifer (von Brömssen et al., 2014; Figure S6) but in the SE and Central deep aquifers, early Holocene groundwater has penetrated deeply into Pleistocene strata but originated at neither the basin margin nor the present land surface. The latter 
did not exist at the time; rather recharge would have been concentrated along the floors of the incised valleys. Further, much of the water in the SC and SW aquifers may no longer be part of active flow systems and may in fact be older than the reported ${ }^{14} \mathrm{C}$ ages suggest, due to effects such as mixing, aquitard diffusion and minor casing leaks. Thus, notwithstanding the uncertainty over age corrections, ${ }^{14} \mathrm{C}$ ages that pre-date about $7 \mathrm{Ka}$ will improve understanding but cannot be used directly for model calibration. Thus, model results must be presented to resource managers and policy makers with appropriate qualifications regarding their accuracy and reliability.

The experience of intensive pumping for municipal supply at Khulna City since the 1960s has led to the perception that deep groundwater abstraction can be sustained for decades and possibly centuries (Hoque et al., 2008; Ravenscroft et al., 2013; Ravenscroft \& McArthur, 2004), however, it would be imprudent to generalise responses between aquifers. The inference of down-gradient closure of the coastal aquifers in the centre of the basin (SI-S5) implies a low risk of sea water intrusion, but vertical leakage of arsenic or brackish water remain significant risks that require sentinel monitoring, further investigations and progressive refinement of numerical models and wellfield layouts - a process of adaptive abstraction management. While the precautionary principle favours conserving deep groundwater for future potable use, exploitation now would provide the most benefit for the greatest number (Ravenscroft et al., 2013), particularly as there is a realistic prospect that deep pumping will induce regional scale in-situ removal of arsenic (Ravenscroft et al., 2009; Stollenwerk et al., 2007). Where such removal occurs, deep aquifers might also be exploited as a source of low-As irrigation water. The utility of the deep groundwater resource could be enhanced by managed recharge of excess surface water during the monsoon.

\section{Conclusion}

The 'deep aquifer' of the Bengal Basin has been divided into eight deep aquifer units on the basis of distinctive combinations of chemical, isotopic and hydraulic properties that are the products of spatially and temporally discrete hydro-climatic and sedimentary processes associated with 
glacio-eustatic changes during the last $125 \mathrm{ka}$. With further research, additional units or sub-units may be defined but what is certain is that deep groundwater cannot be managed scientifically as a single entity. Multiple cycles of incision and interfluvial weathering and pedogenesis created axes of enhanced vertical continuity separated by thin but laterally extensive surfaces of low vertical permeability resulting in preferential pathways for recharge that determine the age and chemistry of groundwater in the deep aquifers. Five periods of recharge to deep aquifers have been recognised but two are quantitatively dominant: water recharged during the LGM, possibly hydraulically trapped, that is low in $\mathrm{Cl}$ and $\mathrm{Fe}$; and water recharged in the terminal Pleistocene to early Holocene that contains high $\mathrm{Fe}$ and slightly higher $\mathrm{Cl}$ concentrations. The younger deep groundwater is spatially associated with the deeply incised LGM palaeochannels of the major regional rivers which facilitated deep groundwater circulation during the post-LGM transgression.

The aquifer units delineated here provide a framework for research and for planning the mitigation of arsenic pollution and saline intrusion that threaten the health and livelihoods of tens of millions of people. Groundwater from all aquifer units except the Sylhet Basin unit meet health guidelines for As and Mn other than in isolated pockets, but regional variations in Fe concentrations will determine how they are exploited. Deep water-levels, the fluctuation of which are influenced by mechanical loadings effects, have been slightly but permanently lowered by pumping near the coast, but further inland exploitation has resulted in greater drawdown in the dry season albeit with substantial recovery in the monsoon. To date, the performance of deep aquifer abstraction in supporting the mitigation of arsenic and salinity has been good, but their long-term ( $>$ c.50 years) performance remains an open question, with potentially different outcomes in different aquifer units, and demands careful monitoring, further investigation, and adaptive management. These findings should have application to other mega-deltas.

\section{- ASSOCIATED CONTENT}

*S Supporting Information 
The Supporting Information is available free of charge on the ? website at DOI:

Details of the database, including well-location, hydrochemistry, piezometry and stable isotopic composition of groundwater, supporting tables, and supporting figures (PDF)

\section{- AUTHOR INFORMATION}

Corresponding Author

*E-mail: RavenscroftP@aol.com; Cambridge, UK. phone: 0044-7837-347623.

Notes

The authors declare no competing financial interest.

\section{- ACKNOWLEDGMENTS}

The work was not supported by any funding agency. We thank two anonymous reviewers for comments that greatly improved this paper. We thank Mr Sudhir Kumar Ghosh, former Chief Engineer of the Department of Public Health Engineering, for his support and encouragement during this work and access to data from the IWM-DPHE in southwest Bangladesh; and also thank Nargis Akter of UNICEF for data on the locations of poor quality deep groundwater in Manoharganj Upazila in Comilla District. 


\section{References}

Aggarwal, P.K., Basu, A.R. \& Poreda, R.J. (2000). Preliminary Report of Investigations. Isotope Hydrology of Groundwater in Bangladesh: Implications for Characterization and Mitigation of Arsenic in Groundwater; IAEA-TC project (BGD/8/016); International Atomic Energy Agency: Vienna.

Alam, M., Alam, M.M., Curray J.R., Chowdhury, M.L.R. \& Gani, M.R. (2003). An overview of the sedimentary geology of the Bengal Basin in relation to the regional tectonic framework and basin-fill history. Sedimentary Geology, 155, 179-208.

Alam, M.K., Hassan, A.K.M.S., Khan, M.R. \& Whitney, J.W. (1990) Geological Map of Bangladesh. Geological Survey of Bangladesh.

Allison, M.A., Khan, S.R., Goodbred, Jr, S.L. \& Kuehl, S.A. (2003). Stratigraphical evolution of the late Holocene Ganges-Brahmaputra lower delta plain. Sedimentary Geology, 155, 317-342.

ATF (2004). Report of the subcommittee of the Arsenic Task Force for identifying arsenic free deeper aquifer in parts of the arsenic infested areas of West Bengal. Kolkata, India. 11pp.

BADC (1992). Final Report of the Deep Tubewell II Project; v 2.1 Natural Resources and v 2.1/3 Groundwater Salinity Study. Mott MacDonald International in association with Hunting Technical Services. Report to Bangladesh Agricultural Development Corporation and Overseas Development Administration, UK, 1992.

BADC (2015). Minor Irrigation Survey Report 2014-15 (Boro season). Bangladesh Agricultural Development Corporation, Dhaka.

Basu A.R., Jacobsen, S.B.; Poreda, R.J.; Dowling, C.B. \& Aggarwal, P.K. (2001). Large groundwater strontium flux to the oceans from the Bengal Basin and the marine strontium isotope record. Science, 293, 1470-1473.

Blum, M.D. \& Törnqvist, T.E. (2000). Fluvial responses to climate and sea level change: a review and look forward. Sedimentology, 47, 2-48. 
Brammer, H. (2012). Physical geography of Bangladesh. University Press Ltd, Dhaka, ISBN: 978984506049.

BRGM (2005). Groundwater resources and hydro-geological investigations in and around Khulna City. Bureau de Recherches Géologiques et Minières. Local Government Engineering Department.

Burgess, W.G., Hoque, M.A., Michael, H.A., Voss, C.I., Breit, G.N. \& Ahmed, K.M. (2010) Vulnerability of deep groundwater in the Bengal Aquifer System to contamination by arsenic. Nature Geoscience, 3, 83-87.

Burgess, W.G., Shamsudduha, M., Taylor, R.G., Zahid, A., Ahmed, K.M., Mukherjee, A., Lapworth, D.J., \& Bense, V.F. (2017) Terrestrial water load and groundwater fluctuation in the Bengal Basin. Scientific Reports, 7: 3872, DOI:10.1038/s41598-017-04159-w.

BWDB (2013). Establishment of Monitoring Network and Mathematical Model Study to Assess Salinity Intrusion in Groundwater in the Coastal Area of Bangladesh due to Climate Change. Final Synthesis Report. Bangladesh Water Development Board and Institute of Water Modelling, under Climate Change Trust Fund, Ministry of Environment and Forest.

Choudhury, I., Ahmed, K.M., Hasan, M., Mozumder, M.R., Knappett, P.S., Ellis, T. \& van Geen, A. (2016) Evidence for elevated levels of arsenic in public wells of Bangladesh due to improper installation. Groundwater; 54, 6, 871-877.

Chowdhury, M.T.A., Meharg, A.A., Deacon, C., Hossain, M. \& Norton, G.J. (2012). Hydrogeochemistry and arsenic contamination of groundwater in the Haor Basins of Bangladesh. Water Quality, Exposure, and Health, 4, 67-78.

Contreras-Rosales, L.A., Jennerjahn, T., Tharammal, T., Meyer, V., Lückge, A., Paul, A. \& Schefuß, E. (2012). Evolution of the Indian Summer Monsoon and terrestrial vegetation in the Bengal region during the past 18 ka. Quaternary Science Reviews, 102, 133-148. 
Curray, J.R., Emmel, F.J. \& Moore, D.G. (2003). The Bengal Fan: morphology, geometry, stratigraphy, history and processes. Marine and Petroleum Geology, 19, 1191-1223.

Darling, W.G., Burgess, W.G. \& Hasan, M.K. (2002). The application of isotope techniques to the assessment of aquifer systems in major urban areas, pp. 95-107, TECDOC 1298, International Atomic Energy Agency (IAEA), Vienna.

De Silva, S., Wightman, N.R. \& Kamruzzaman, M. (2010). Geotechnical ground investigation for the Padma Main Bridge. In: Amin, Okui, Bhuiyan (eds.), IABSE-JSCE Joint Conference on Advances in Bridge Engineering-II, Dhaka, Bangladesh. ISBN: 978-984-33-1893-0. www.iabse-bd.org.

DPHE (1999). Groundwater Studies for Arsenic Contamination in Bangladesh. Phase I: Rapid Investigation; Department of Public Health Engineering, Government of Bangladesh, Mott MacDonald Ltd (UK), and British Geological Survey, 6 vols.

DPHE (2001). Arsenic contamination of groundwater in Bangladesh Department of Public Health Engineering and British Geological Survey BGS Technical Report WC/00/19.

DPHE-DANIDA (2001). Hydrogeology Summary Report DPHE-DANIDA Water Supply and Sanitation Components. Report to Department of Public Health Engineering (Bangladesh) and Ministry of Foreign Affairs (Denmark) by DHV Consultants, AQUA Consultant and DEVCON Ltd.

DPHE-JICA (2002). The study on ground water development of deep aquifers for safe drinking water supply to arsenic affected areas in western Bangladesh. Report to JICA and Department of Public Health Engineering by Kokusai Kogyo Ltd and Mitsui Mineral Development Engg Ltd, Japan.

DPHE-JICA (2008). Drilling deep tubewells in gravel problem area using improved water jet method. Department of Public Health Engineering (Bangladesh) and Japanese International Cooperation Agency. 
Dray, M. (1982). Isotope water study of Bangladesh; Final Report. Groundwater Survey BGD/74/009. International Atomic Energy Agency and United Nations Development Program.

GoB (2004). National Policy on Arsenic Mitigation, and Its Implementation Plan. Government of Bangladesh: Dhaka, Bangladesh.

Goodbred, S.L. (2003). Response of the Ganges dispersal system to climate change; a source-tosink view since the last interstade. Sedimentary Geology, 162, 83-104.

Goodbred Jr., S.L. \& Kuehl, S.A. (2000a). The significance of large sediment supply, active tectonism, and eustasy on margin sequence development: Late Quaternary stratigraphy and evolution of the Ganges-Brahmaputra delta. Sedimentary Geology, 133, 227-248.

Goodbred, Jr., S.L. \& Kuehl, S.A. (2000b). Enormous Ganges-Brahmaputra sediment discharge during strengthened early Holocene monsoon. Geology, 28, 1083-1086.

Goodbred, Jr., S.L., Paolo, P.M., Ulla, M.S., Pate, R.D., Khan, S.R., Kuehl, S.A., Singh, S.K. \& Rahaman, W. (2014). Piecing together the Ganges-Brahmaputra-Meghna River delta: use of sediment provenance to reconstruct the history and interaction of multiple fluvial systems during Holocene delta evolution. Geological Society of America Bulletin, 126, 1495-1510.

Harvey, C.F., Swartz, C.H., Badruzzaman, A.B.M., Keon-Blute, N., Yu, W., Ali, M.A., Jay, J., Beckie, R., Niedan, V., Brabander, D., Oates, P.M., Ashfaque, K.N., Islam, S., Hemond, H.F. \& Ahmed, M.F. (2002). Arsenic mobility and groundwater extraction in Bangladesh. Science, 298, $1602-1606$.

Harvey, C.F. (2002). Groundwater flow in the Ganges delta. Science, 296, 1563A.

Hoque, M., Hasan, M.K. \& Ravenscroft, P. (2003). Investigation of groundwater salinity and gas problems in southeast Bangladesh. In: Rahman, A.A. \& Ravenscroft, P. (Eds). Groundwater Resources and Development in Bangladesh. Bangladesh Centre for Advanced Studies University Press Ltd, Dhaka, 373-390. 
Hoque, M.A., Burgess, W.G. \& Ahmed, K.M. (2008). Is the 'Khulna Experience' a useful indication of the sustainability of groundwater abstraction from deep aquifers in arsenic-affected southern Bangladesh? Geological Society of America Abstracts with Programs, 40(6), 524. https:/gsa.confex.com/gsa/2008AM/finalprogram/abstract_148170.htm

Hoque, M.A., Hoque, M.M. \& Ahmed, K.M. (2007). Declining groundwater level and aquifer dewatering in Dhaka metropolitan area, Bangladesh: causes and quantification. Hydrogeology Journal, 15, 1523-1534.

Hoque, M.A., McArthur, J.M., Sikdar, P.K. (2012). The palaeosol model of arsenic pollution of groundwater tested along a $32 \mathrm{~km}$ traverse across West Bengal, India. Science of the Total Environment, 431, 157-165.

Hoque, M.A.; McArthur, J.M. \& Sikdar, P.K. (2014a). Sources of low-arsenic groundwater in the Bengal Basin: investigating the influence of the last glacial maximum palaeosol using a $115-\mathrm{km}$ traverse across Bangladesh. Hydrogeology Journal, 22, 1535-1547.

Hoque, M.A., McArthur, J.M., Sikdar, P.K., Marshall, J.D. \& Molla, T.N. (2014b). Tracing recharge to aquifers beneath an Asian megacity - the example of Dhaka, Bangladesh. Hydrogeology Journal, 22, 1549-1560. DOI 10.1007/s10040-014-1155-8.

Hübscher, C., Breitzke, M., Michels, K., Kudraß, H., Spieß, V. \& Wiedicke, M. (1998) Late Quaternary seismic stratigraphy of the eastern Bengal Shelf. Mar. Geophys. Res; 20 (1), 57- 71.

Hübscher, C. \& Spieß, V. (2005). Forced regression systems tracts on the Bengal Shelf. Marine Geology, 219, 207-218.

Hug, S.J., Gaertner, D., Roberts, L.C., Schirmer, M., Ruettimann, T., Rosenberg, T.M., Badruzzaman, A.B.M. \& Ali, M.A. (2011). Avoiding high concentrations of arsenic, manganese and salinity in deep tubewells in Munshiganj District, Bangladesh. Applied Geochemistry, 26, $1077-1085$. 
Inauen, J., Hossain, M.M., Johnston, R.B. \& Mosler, H-J. (2013). Acceptance and use of eight arsenic-safe drinking water options in Bangladesh. PLoS ONE, 8, e53640. doi:10.1371/journal.pone.0053640.

IWM (2015). 148 Paurashavas Masterplan project: data compilation for Department of Public Health Engineering by Institute of Water Modelling, Dhaka.

JICA-UNICEF (2005). Practical approach for efficient safe water option. JICA and UNICEF for the Department of Public Health Engineering, Bangladesh.

Johnson, S.Y. \& Alam, A.M.N. (1991). Sedimentation and tectonics of the Sylhet Trough, Bangladesh. Geological Society of America Bulletin, 103, 1513-1527.

Johnston, R.B., Hug, S.J., Inauen, J., Khan, N.I., Mosler, H-J. \& Yang, H. (2013). Enhancing arsenic mitigation in Bangladesh: findings from institutional, psychological and technical investigations. Science of the Total Environment, 488, 481-487.

Jones, P.H. (1985). Geology and groundwater resources of Bangladesh. P H Jones Hydrogeology Inc. World Bank (Asia Division).

Khan, F.H. (1991). Geology of Bangladesh. University Press, Dhaka.

Knappett, P.S.K., Mailloux, B.J., Choudhury, I., Khan, M.R., Michael, H.A., Barua, S., Mondal, D.R., Steckler, M.S., Akhter, S.H., Ahmed, K.M., Bostick, B., Harvey, C.F., Shamsudduha, M., Shuai, P., Mihajlov, I., Mozumder, R. \& van Geen, A. (2016). Vulnerability of low-arsenic aquifers to municipal pumping in Bangladesh. Journal of Hydrology, 539, 674-686.

Kooi, H. (1999). Competition between topography- and compaction-driven flow in a confined aquifer: Some analytical results. Hydrogeology Journal, 7, 245-250.

Kooi, H. \& Groen, J. (2003). Geological processes and the management of groundwater resources in coastal areas. Geologie en Mijnbouw, 82, 31-40. 
LGD (2011). Sector Development Plan (FY 2011-25). Local Government Division, Ministry of Local Government, Rural Development and Cooperatives, Bangladesh.

Lusczynski, N.J. (1961). Head and flow of ground water of variable density. Journal of Geophysical Research, 66, 4247-4256.

McArthur, J.M., Ravenscroft, P., Safiullah, S. \& Thirlwall, M.F. (2001). Arsenic in groundwater: testing pollution mechanisms for sedimentary aquifers in Bangladesh. Water Resources Research, 37, 109-117.

McArthur, J.M., Banerjee, D. M., Hudson-Edwards, K. A., Mishra, R., Purohit, R., Ravenscroft, P., Cronin, A., Howarth, R.J., Chatterjee, A., Talukder, T., Lowry, D., Houghton, S. \& Chadha, D. (2004). Natural organic matter in sedimentary basins and its relation to arsenic in anoxic groundwater: the example of West Bengal and its worldwide implications. Applied Geochemistry, 19, 1255-1293.

McArthur, J. M., Ravenscroft, P., Banerjee, D. M., Milsom, J., Hudson-Edwards, K. A., Sengupta, S., Bristow, C., Sarkar, A., Tonkin, S. \& Purohit, R. (2008). How palaeosols influence groundwater flow and arsenic pollution: A model from the Bengal Basin and its worldwide implication. Water Resources Research, 44, W11411.

McArthur, J.M., Ghosal, U., Sikdar, P.K. \& Ball, J.D. (2016). Arsenic in groundwater: the deep late Pleistocene aquifers of the western Bengal Basin. Environmental Science and technology, 50, 3469-76.

Michael, H.A. \& Voss, C.I. (2008). Evaluation of the sustainability of deep groundwater as an arsenic-safe resource in the Bengal Basin Proceedings of the National Academy of Sciences, $105,8531-8536$.

Michael, H.A. \& Voss, C.I. (2009a). Estimation of regional-scale groundwater flow properties in the Bengal Basin of India and Bangladesh. Hydrogeology Journal, 17, 1329-1346. 
Michael, H.A. \& Voss, C.I. (2009b). Controls on groundwater flow in the Bengal Basin of India and Bangladesh: regional modeling analysis. Hydrogeology Journal, 17, 1561-1577.

Mihajlov, I., Stute, M., Schlosser, P., Mailloux, B.J., Zheng, Y., Choudhury, I., Ahmed, K.M. \& van Geen, A. (2016). Recharge of low-arsenic aquifers tapped by community wells in Araihazar, Bangladesh, inferred from environmental isotopes. Water Resources research, 52, $3324-3349$.

Moore, W.S. (1997). High fluxes of radium and barium from the mouth of the GangesBrahmaputra River during low river discharge suggest large groundwater source. Earth and Planetary Science Letters, 150, 141.

Morgan, J.P. \& McIntire, W.G. (1959). Quaternary geology of the Bengal Basin, East Pakistan and India. Geological Society of America Bulletin, 70, 319-342.

Morton, W. \& Khan, A.Q. (1979). Groundwater in the coastal zone and offshore islands of Bangladesh. UNDP/UNDTCD Ground Water Survey. Technical Report Nr 2. BGD/74/009. BWDB Water Supply Paper 416.

Mosler, H-J., Blöchliger, O.R. \& Inauen, J. (2010). Personal, social, and situational factors influencing the consumption of drinking water from arsenic-safe deep tubewells in Bangladesh. Journal of Environmental Management, 91, 1316-1323.

MPO (1987). Groundwater Resources of Bangladesh. Technical Report Nr 5. Master Plan Organisation. Dhaka. Harza Engineering, USA in association with Sir M MacDonald \& Partners, UK, Meta Consultants, USA and EPC Ltd, Dhaka.

Mukherjee, A. \& Fryar, A.E. (2008). Deeper groundwater chemistry and geochemical modeling of the arsenic affected western Bengal basin, West Bengal, India. Applied Geochemistry, 23, 863-894. 
Mukherjee, A., Fryar, A.E. \& Howell, P.D. (2007a). Regional hydrostratigraphy and groundwater flow modelling in the arsenic-affected areas of the western Bengal basin, West Bengal, India. Hydrogeology Journal, 15, 1397-1418.

Mukherjee, A., Fryar, A.E. \& Rowe, H.D. (2007b). Regional-scale stable isotopic signatures of recharge and deep groundwater in the arsenic affected areas of West Bengal, India. Journal of Hydrology, 334, 151-161.

Mukherjee, A., Fryar, A.E., Scanlon, B.R., Bhattacharya, P. \& Bhattacharya, A. (2011). Elevated arsenic in deeper groundwater of the western Bengal Basin, India: extent and controls from regional to local scale. Applied Geochemistry, 26, 600-613.

Nickson, R., McArthur, J., Burgess, W., Ahmed, M., Ravenscroft, P. \& Rahman, M. (1998). Arsenic poisoning of groundwater in Bangladesh. Nature, 395, 338.

Pickering, J.L., Goodbred Jr, S.L., Reitz, M.D., Hartzog, T.R., Mondal, D.R. \& Hossain, M.S. (2014). Late Quaternary sedimentary record and Holocene channel avulsions of the Jamuna and Old Brahmaputra River valleys in the upper Bengal delta plain. Geomorphology, 227, 123-136.

Pickering, J.L., Goodbred, Jr, S.L., Beam, J.C., Ayers, J.C., Covey, A.K., Rajapara, H.M. \& Singh, A.K. (2017). Terrace formation in the upper Bengal Basin since the Middle Pleistocene: Brahmaputra fan delta construction during multiple highstands. Basin Research, 1-18, DOI:10.1111/bre.12236.

Post, V., Kooi, H. \& Simmons, C. (2007). Using hydraulic head measurements in variable-density ground water flow analyses. Ground Water; 6, 664-671.

Post, V., Groen, J., Kooi, H., Person, M., Ge, S., Edmunds, W.M. (2013). Offshore fresh groundwater reserves as a global phenomenon. Nature, 504, 71-78. 
PSU (2011). Water safety framework in Bangladesh. Policy Support Unit, Ministry of Local Government, Rural Development and Cooperatives, Bangladesh and World Health Organization.

Radloff, K.A., Zheng, Y., Michael, H.A., Stute, M., Bostick, B.C., Mihajlov, I., Bounds, M., Huq, M.R., Choudhury, I., Rahman, M.W., Schlosser, P., Ahmed, K.M. \& van Geen, A. (2011). Arsenic migration to deep groundwater in Bangladesh influenced by adsorption and water demand. Nature Geoscience, 4, 793-798.

Ravenscroft, P. (2003). An Overview of the Hydrogeology of Bangladesh In: Rahman, A.A. \& Ravenscroft, P. (Eds.) Groundwater Resources and Development in Bangladesh. Bangladesh Centre for Advanced Studies University Press Ltd, Dhaka, 43-86.

Ravenscroft, P. \& McArthur, J.M. (2004). Mechanism of regional pollution of groundwater by boron: the examples of Bangladesh and Michigan, USA. Applied Geochemistry, 19, 1413-1430.

Ravenscroft, P., McArthur, J.M. \& Hoque, B. (2001). Geochemical and palaeohydrological controls on pollution of groundwater by arsenic. Arsenic Exposure and Health Effects IV; Chappell, W. R., Abernathy, C.O., Calderon, R., Eds.; Elsevier Science Ltd.: Oxford, 53-77.

Ravenscroft, P. Brammer, H. \& Richards, K.S. (2009). Arsenic Pollution: A Global Synthesis. Wiley-Blackwell, Oxford, UK, 580 pp. Doi: 10.1002/9781444308785.index.

Ravenscroft, P., McArthur, J.M. \& Hoque, M. (2013). Stable groundwater quality in deep aquifers of southern Bangladesh: the case against sustainable abstraction. Science of the Total Environment, 454-455, 627-638.

Ravenscroft, R., Kabir, A., Ibn Hakim, S.A., Ibrahim, A.K.M., Ghosh, S.K., Rahman, M.S., Akhter, F. \& Sattar, M.A. (2014). Effectiveness of public rural waterpoints in Bangladesh with special reference to arsenic mitigation. Journal of Water, Sanitation and Hygiene for Development, 4, 545-562. 
Rus, J.S. (1985). Geohydrological Investigations in Khulna. DPHE Water Supply and Sanitation Projects. DPHE. Netherlands - Bangladesh Development Co-operation Programme.

Sengupta, S. \& Sarkar, A. (2006). Stable isotope evidence of dual (Arabian Sea and Bay of Bengal) vapour sources in monsoonal precipitation over north India. Earth and Planetary Science letters, 250, 511-521.

Shamsudduha, M. \& Uddin, A. (2007). Quaternary shoreline shifting and hydrogeologic influence on the distribution of groundwater arsenic in aquifers of the Bengal Basin. Journal of Asian Earth Science, 31, 177-194.

Shibasaki, N., Lei, P. \& Kamata, A. (2007). Evaluation of deep groundwater development for arsenic mitigation in western Bangladesh. Journal of Environmental Science and Health Part A, 42, 1919-1932.

Smith, A.H., Lingas, E.O. \& Rahman, M. (2000). Contamination of drinking-water by arsenic in Bangladesh: a public health emergency. Bulletin of the World Health Organization, 78, 10931103.

Stahl, M.O., Ong, J.B., Harvey, C.F., Johnson, C.D., Badruzzaman, A.B.M., Tarek, M.H., van Geen, A., Anderson, J.A. \& Lane, J.W. (2014). Detecting Well Casing Leaks in Bangladesh Using a Salt Spiking Method. Groundwater, 52, 195-200.

Steckler, M.S., Mondal, D.R., Akhter, S.H., Seeber, L., Feng, L., Gale, J., Hill, E.M. \& Howe, M. (2016). Locked and loading megathrust linked to active subduction beneath the Indo-Burman Ranges. Nature Geoscience, 9, 615-619.

Stollenwerk, K.G., Breit, G.N., Welch, A.H., Yount, J.C., Whitney, J.W., Foster, A.L., Uddin, M.N., Majumder, R.K. \& Ahmed, N. (2007). Arsenic attenuation by oxidized aquifer sediments in Bangladesh. Science of the Total Environment, 379, 133-150. 
Toth, J. (1970). A conceptual model of the groundwater regime and the hydrogeologic environment. Journal of Hydrology, 10, 164-176.

UKTAG (2012). Defining and Reporting on Groundwater Bodies. UK Technical Advisory Group on the Water Framework Directive. https://www.wfduk.org/resources\%20/defining-andreporting-groundwater-bodies accessed 24/1/2017.

UNICEF-VERC. United Nations Children's Fund and Village Education Resource Center (VERC), Bangladesh; unpublished data on Manoharganj, Comilla District.

van Geen, A., Zheng, Y., Versteeg, R., Stute, M., Horneman, A., Dhar, R., Steckler, M., Gelman, A., Small, C., Ahsan, H., Graziano, J., Hussein, I. \& Ahmed, K.M. (2003). Spatial variability of arsenic in 6000 tube wells in a $25 \mathrm{~km}^{2}$ area of Bangladesh. Water Resources Research, 39, $1140-1155$.

van Geen, A., Ahmed, K.M., Ahmed, E.B. Choudhury, I. Mozumder, M.R., Bostick B.C. \& Mailloux B.J. (2016). Inequitable allocation of deep community wells for reducing arsenic exposure in Bangladesh. Journal of Water Sanitation and Hygiene for Development, 6, 142 150.

von Brömssen, M., Markussen, L., Bhattacharya, P., Ahmed, K.M., Hossain, M., Jacks, G., Sracek, O., Thunvik, R., Hasan, M.A., Islam, M.M. \& Rahman, M.M. (2014). Hydrogeological investigation for assessment of the sustainability of low-arsenic aquifers as a safe drinking water source in regions with high-arsenic groundwater in Matlab, southeastern Bangladesh. Journal of Hydrology, 518, C, 373392.

WARPO (2001). National Water Management Plan. Water Resources Planning Organisation, Ministry of Water Resources, Bangladesh.

Whitney J.W., Pavich, M.J., Huq, M.A. \& Khorshed Alam, A.K.M. (1999). The age and isolation of the Madhupur and Barind Tracts, Ganges - Brahmaputra Delta, Bangladesh. International 
Seminar on the Quaternary Development and Coastal Hydrodynamics of the Ganges Delta in Bangladesh, 20-21 September. Geological Survey of Bangladesh, Dhaka.

Wiedicke, M., Kudraß, H.R. \& Hübscher, C. (1999). Oolith beach barriers of the last glacial sealevel lowstand at the outer Bengal Shelf. Mar. Geol.; 157, 7- 18.

Wilson, C.A. \& Goodbred, Jr, S.L. (2015). Construction and maintenance of the GangesBrahmaputra-Meghna Delta: linking process, morphology, and stratigraphy. Annual Review of Marine Science, 7, 67-88.

Zheng, Y., van Geen, A., Stute, M., Dhar, R., Mo, Z., Cheng, Z., Horneman, A., Gavrieli, I., Simpson, H.J., Versteeg, R., Steckler, M. Grazioli-Venier, A., Goodbred, S., Shahnewaz, M., Shamsudduha, M., Hoque, M.A. \& Ahmed, K.M. (2005). Geochemical and hydrogeological contrasts between shallow and deeper aquifers in two villages of Araihazar, Bangladesh: Implications for deeper aquifers as drinking water sources. Geochim. Cosmochim. Acta, 69, 5203-5218. 


\section{LIST OF TABLES}

Table 1. Deep Aquifer Units 


\section{LIST OF FIGURES}

Fig. 1. Map of Proposed Deep Aquifer Units in Bangladesh. Aquifer units (blue italics): CC Chittagong Coast, Ce - Central, SB - Sylhet Basin, M- Madhupur, SC - Southcentral, SE Southeast, SW - Southwest, W - Western. Abbreviated place names are: Az - Araihazar, Ba - Barisal, Bh - Bhola, Ch - Chuadanga, Cx - Cox's Bazaar, Je - Jessore, Jn - Jhenaidah, Kh - Khulna, Ku - Kutubdia, La - Lakshmipur, Mu - Murshidabad, No - Noakhali, Sy Sylhet; Su - Sunamganj. Physical features (capitalised): BT - Barind Tract, CHT Chittagong Hill Tracts, ME - Meghna Estuary, MT- Madhupur Tract, SMF -Sundarban mangrove forest. Grey lines are District boundaries. The palaeosol subcrop is from Hoque et al. (2014a).

Fig. 2. As vs depth in the Sylhet Basin, South-Central and Southeast deep aquifers. Sample numbers: South-Central 3,173; South-East 3,152; and Sylhet Basin 1,137.

Fig. 3. Interpolated surfaces of As, Fe and Mn concentrations in DTWs. Data from the multiple sources listed in the text. The numbers of data points are As 3,402; Fe 24,398; and Mn 1,664. Surfaces interpolated using ArcView Spatial Analyst ${ }^{\circledR}$ using the inverse distance weighted routine for 12 nearest neighbours, a power of 2 and no barriers; output surfaces were clipped to show results for a $3 \mathrm{~km}$ mask created around data points.

Fig. 4. Chloride concentrations at different depths in deep aquifers. The depth slices were selected as $150-200 \mathrm{~m}, 200-250 \mathrm{~m}, 250-300 \mathrm{~m}$ and $>300 \mathrm{~m}$ with sample numbers of $783,8,560$, 11,768 and 2,648 respectively. The surfaces were calculated using the same procedure as used for Figure 3.

Fig. 5. Isotopic composition of deep groundwater: (a) $\delta^{18} \mathrm{O} / \delta^{2} \mathrm{H}$ composition in southern aquifers; (b) $\delta^{18} \mathrm{O} / \delta^{2} \mathrm{H}$ composition in northern aquifers; (c) ${ }^{14} \mathrm{C}$ activity as a function of depth; and (d) $\delta^{18} \mathrm{O}$ and ${ }^{14} \mathrm{C}$ activity. The Local Meteoric Water Line was derived in West Bengal 
(Sengupta et al., 2006). For details of data sources, refer to Tables S3 and S4. Three saline waters with $\mathrm{EC}>10,000 \mu \mathrm{S} / \mathrm{cm}$ were omitted.

Fig. 6. Plots of $\delta^{18} \mathrm{O}$ against well depth in adjoining deep aquifer units.

Fig 7. Vertical head differences and selected hydrographs from deep and shallow aquifers. The data sources are DPHE monitoring of dry season depth-to-water in adjacent deep (in theory $>150$ $\mathrm{m}$, but in some areas less) and shallow wells. From experience, and because the wells are close (at least within the same village), they are assumed to be at the same elevation and the depths to water were subtracted from each other to indicate whether the hydraulic gradient is upward or downward. The hydrographs are from nested piezometers reported in BWDB (2013), although for clarity only one deep $(\geq 178 \mathrm{~m})$ and one shallow $(\leq 67 \mathrm{~m})$ hydrograph are shown from each nest, which are shown in blue and red respectively. Note, water levels are shown as depths to water below ground level; and piezometers are screened in fresh $(\leq 2000$ $\mu \mathrm{S} / \mathrm{cm}$ ) water except for the shallow piezometers at Barguna and Noakhali, which if corrected for density would increase the observed downward gradient.

Fig. 8. Major and minor ion composition for groundwater from Barisal in the SC Aquifer and Lakshmipur in the SE Aquifer (Ravenscroft et al., 2013; DPHE, 2001). 


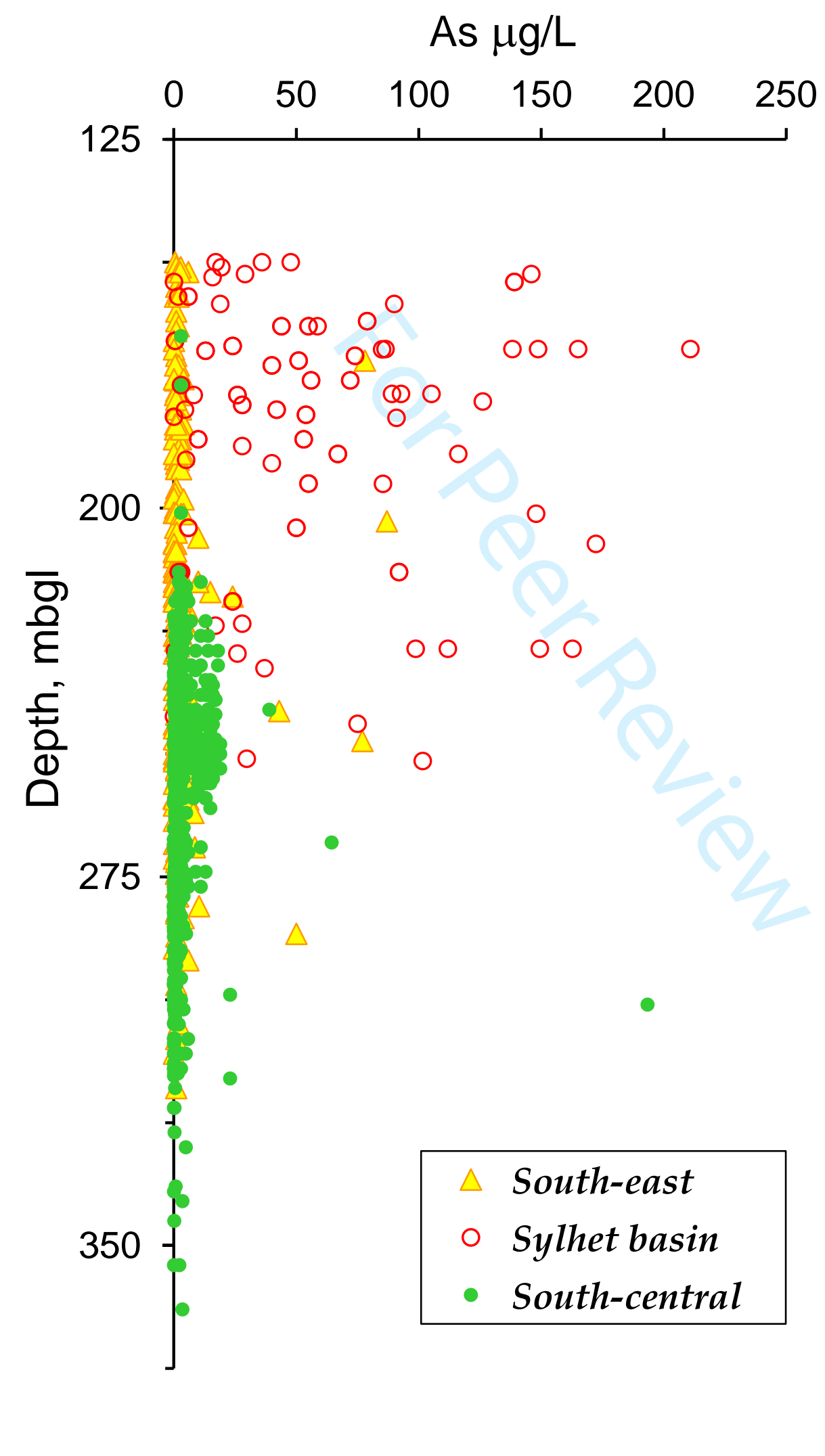

http://mc.manuscriptcentral.com/hyp 


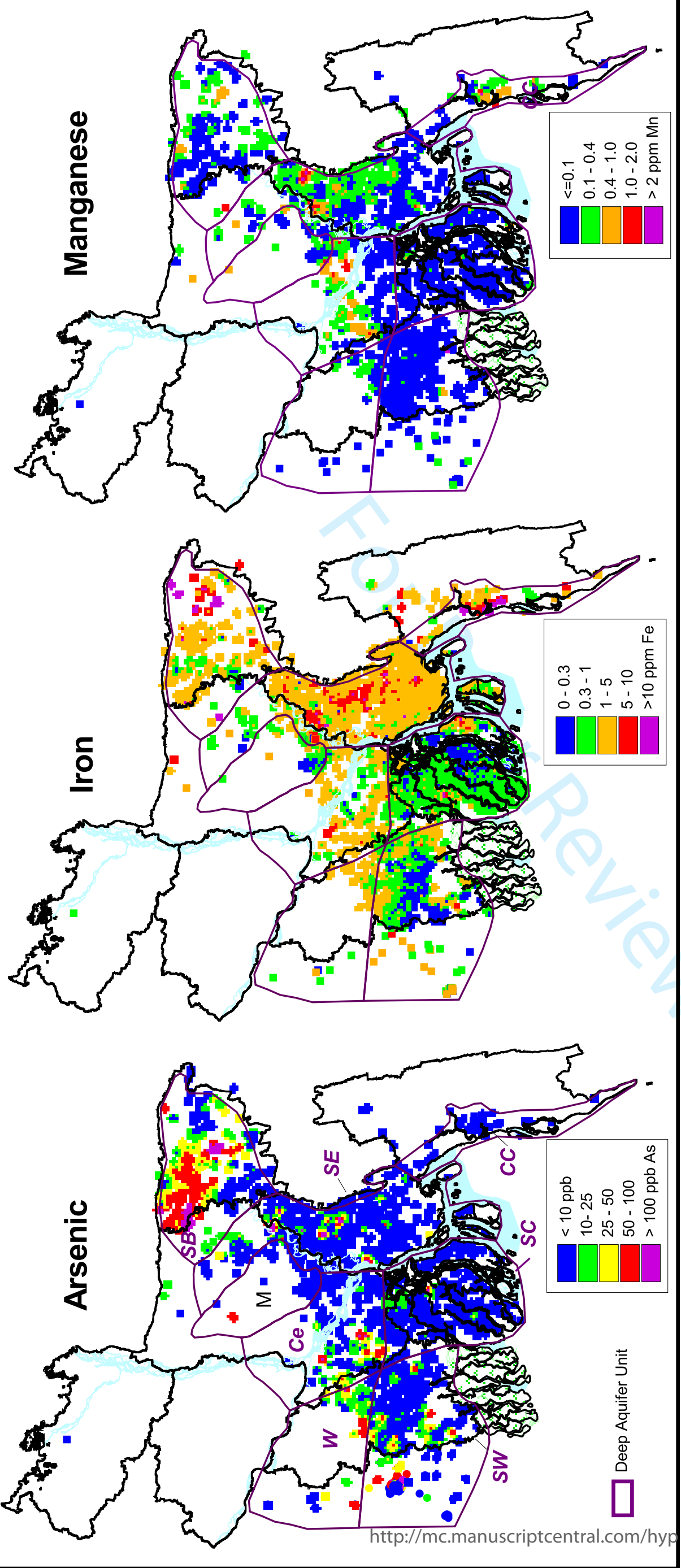



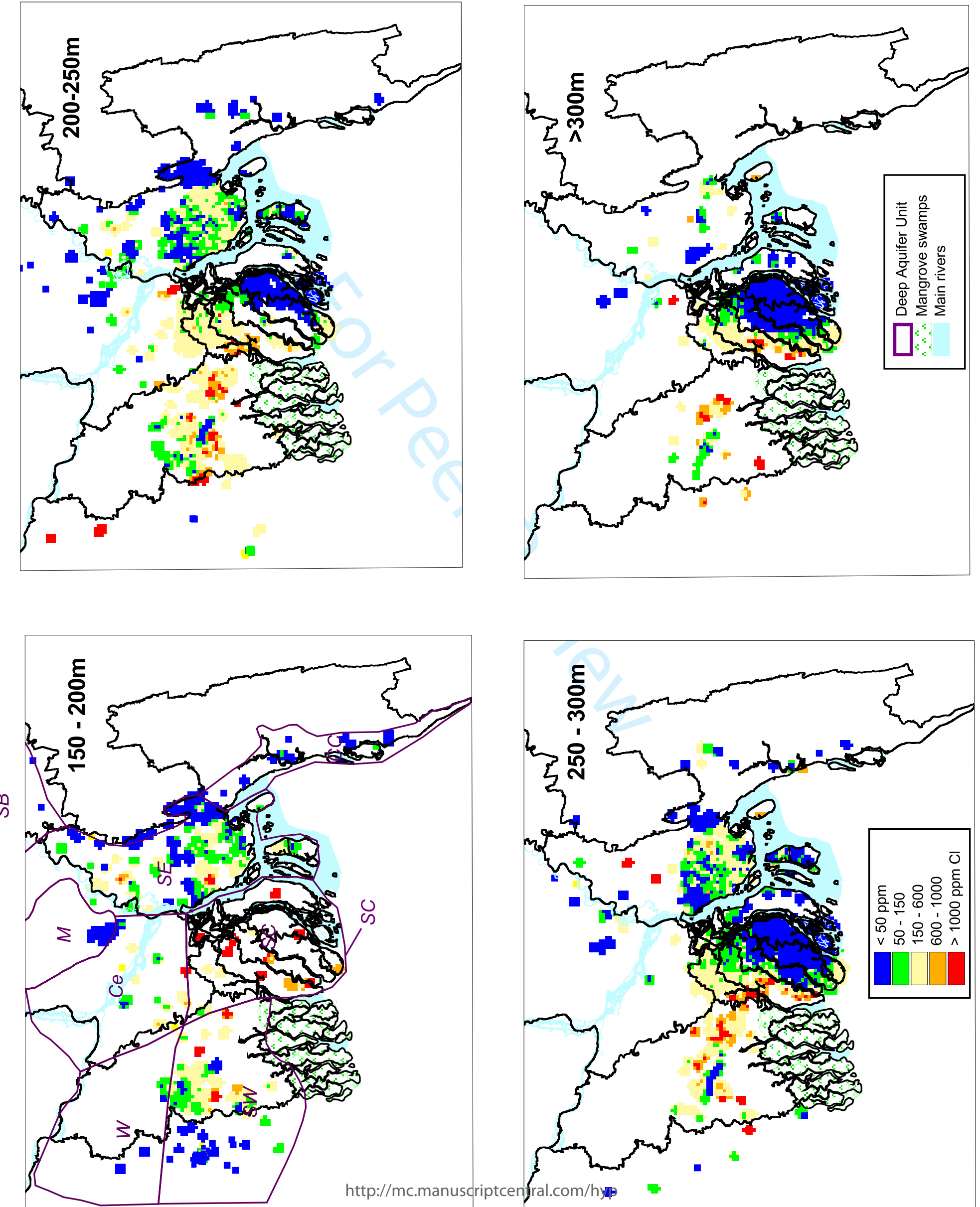

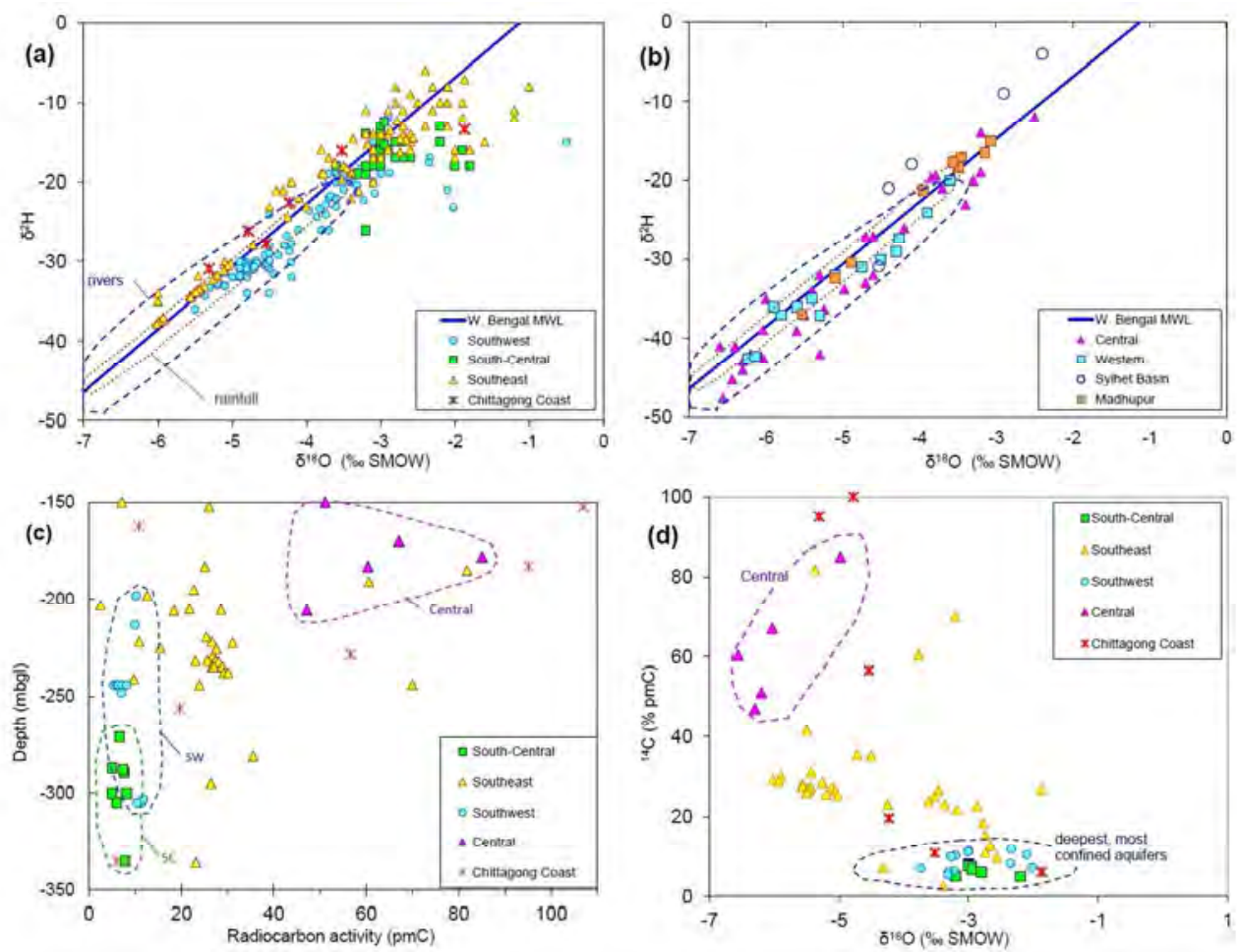

$243 \times 183 \mathrm{~mm}(144 \times 144$ DPI $)$

http://mc.manuscriptcentral.com/hyp 

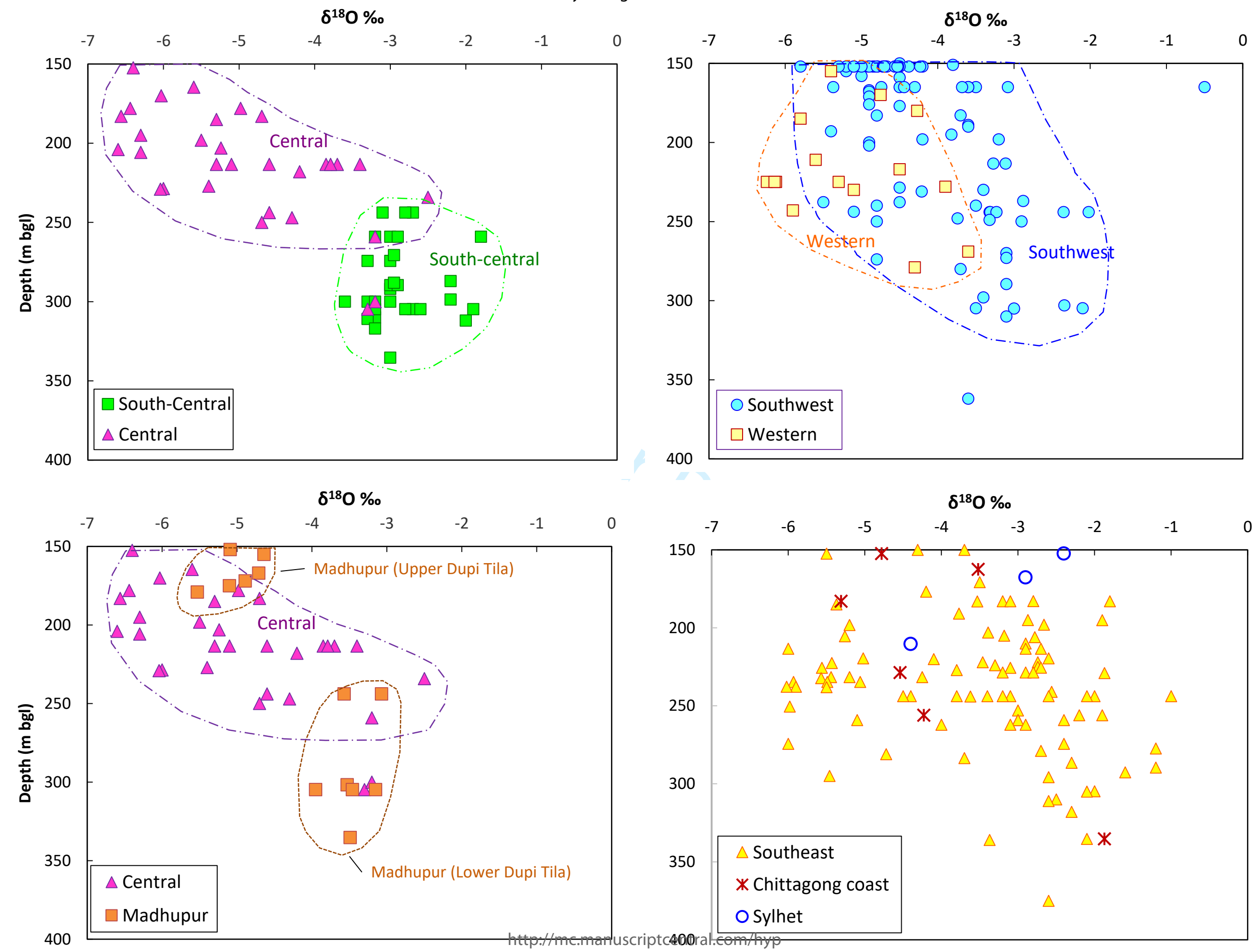

Fig5 BGD stable isotopes deep with WestBengal reclassified.xls Fig 6 _018 depth plots 


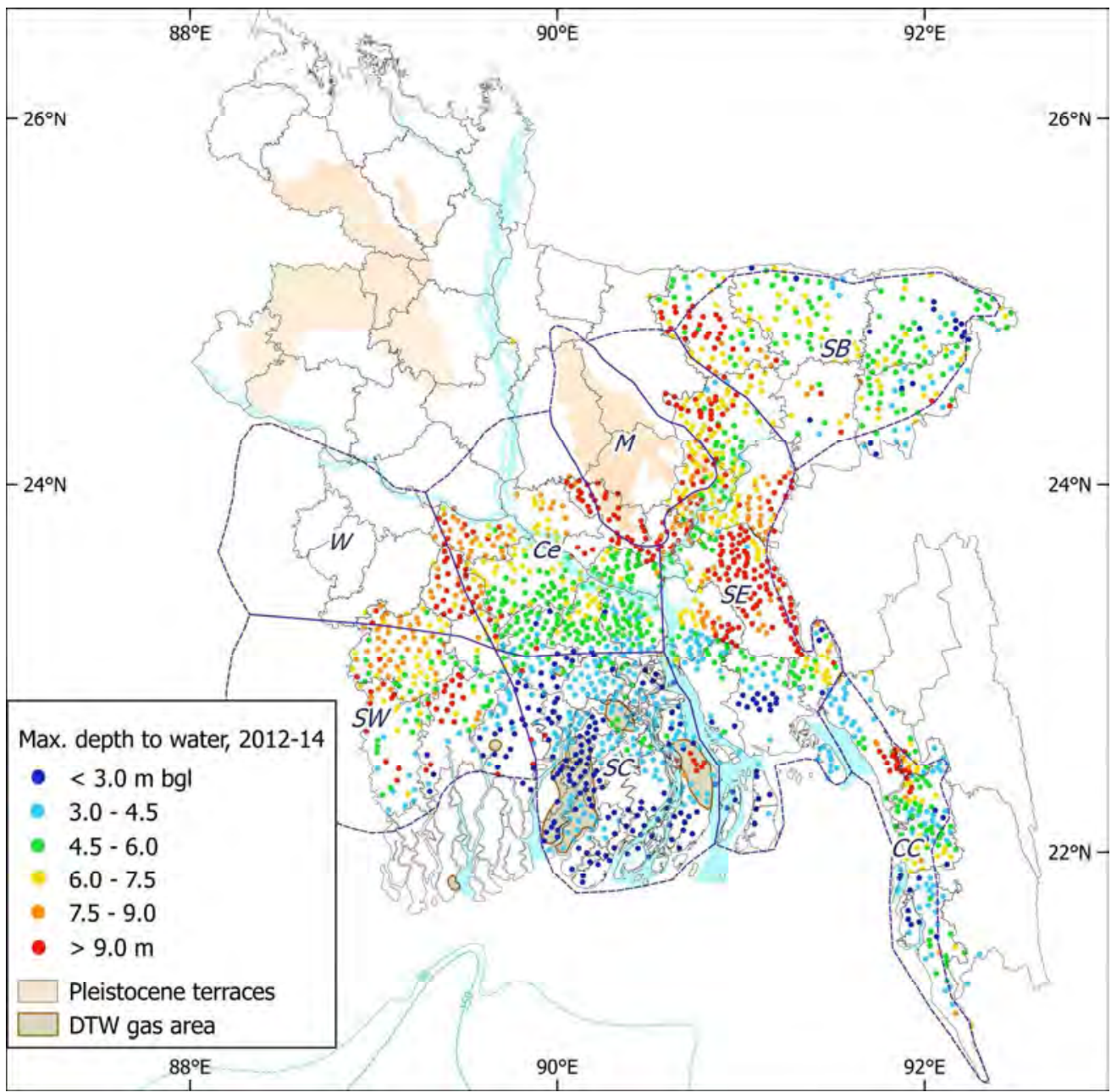

192x189mm (300 x 300 DPI)

http://mc.manuscriptcentral.com/hyp 

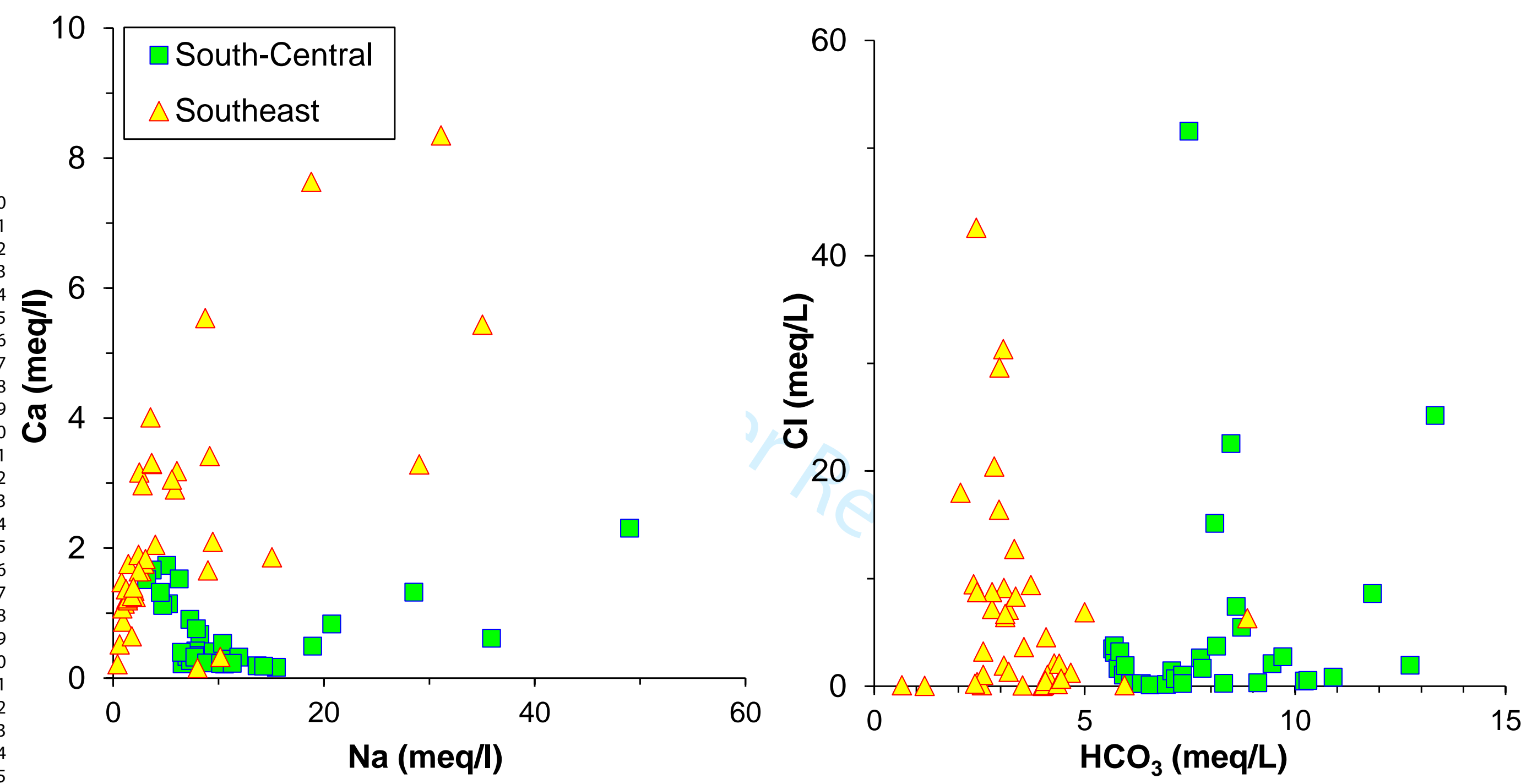


\section{SUPPORTING INFORMATION}

Identifying Multiple Deep Aquifers in the Bengal Basin: Implications for Resource Management

\section{P. Ravenscroft ${ }^{* \dagger}$, J.M. McArthur ${ }^{\S}$, M.S. Rahman"}

*Independent Consultant, Cambridge, UK. Email: ravenscroftp@aol.com

${ }^{\S}$ Earth Sciences, University College London, Gower Street, London WC1E 6BT

" Department of Public Health Engineering, DPHE Bhaban, 14, Shaheed Captain Mansur Ali Sarani, Kakrail, Dhaka-1000, Bangladesh

S1. Data Sources and Processing

S2. Deep Aquifer Lithology

S3. Isotopic Composition of Deep Groundwater

S4. Water Level Information on the Deep Aquifer

S5. Additional Information on the South-Central Deep Aquifer 


\section{Supporting Tables}

S1. Summary of Depth and Chemical Data in Deep Groundwater Database

S2. Frequency of chloride concentrations in deep aquifers

S3. Stable Isotope Data $\left(\delta^{2} \mathrm{H} \%\right.$ and $\delta^{18} \mathrm{O} \%$ ) in Deep Groundwater

S4. Radiocarbon measurements in Deep Groundwater 


\section{Supporting Figures}

Fig S1. Distribution of Deep Tubewells by District.

Fig S2. Distribution of DTW Depths in Different Aquifer Units

Fig S3. Location of Deep Well data points

Fig S4. Examples of Arsenic 'Hot Spots' in Deep Aquifers

Fig S5. Typical Lithological Logs of Selected DTWs in Different Aquifers

Fig S6. Groundwater Ages as a Function of Depth

Fig S7. Maximum depth to water in DPHE DTWs 2012 - 2014

Fig S8. Hydrographs of Density Adjusted Freshwater Head at Piezometer IWM-DPHE Nests in the SW Aquifer

Fig S9. Plot of Density Adjusted Freshwater Head against salinity (as EC)

Fig. S10. Photograph of flowing artesian well on Bhola Island

Fig.S11 Offshore projection of the SC deep aquifer

Fig S12. Maps of (a) boron and (b) chloride distribution in and around the SC deep aquifer 


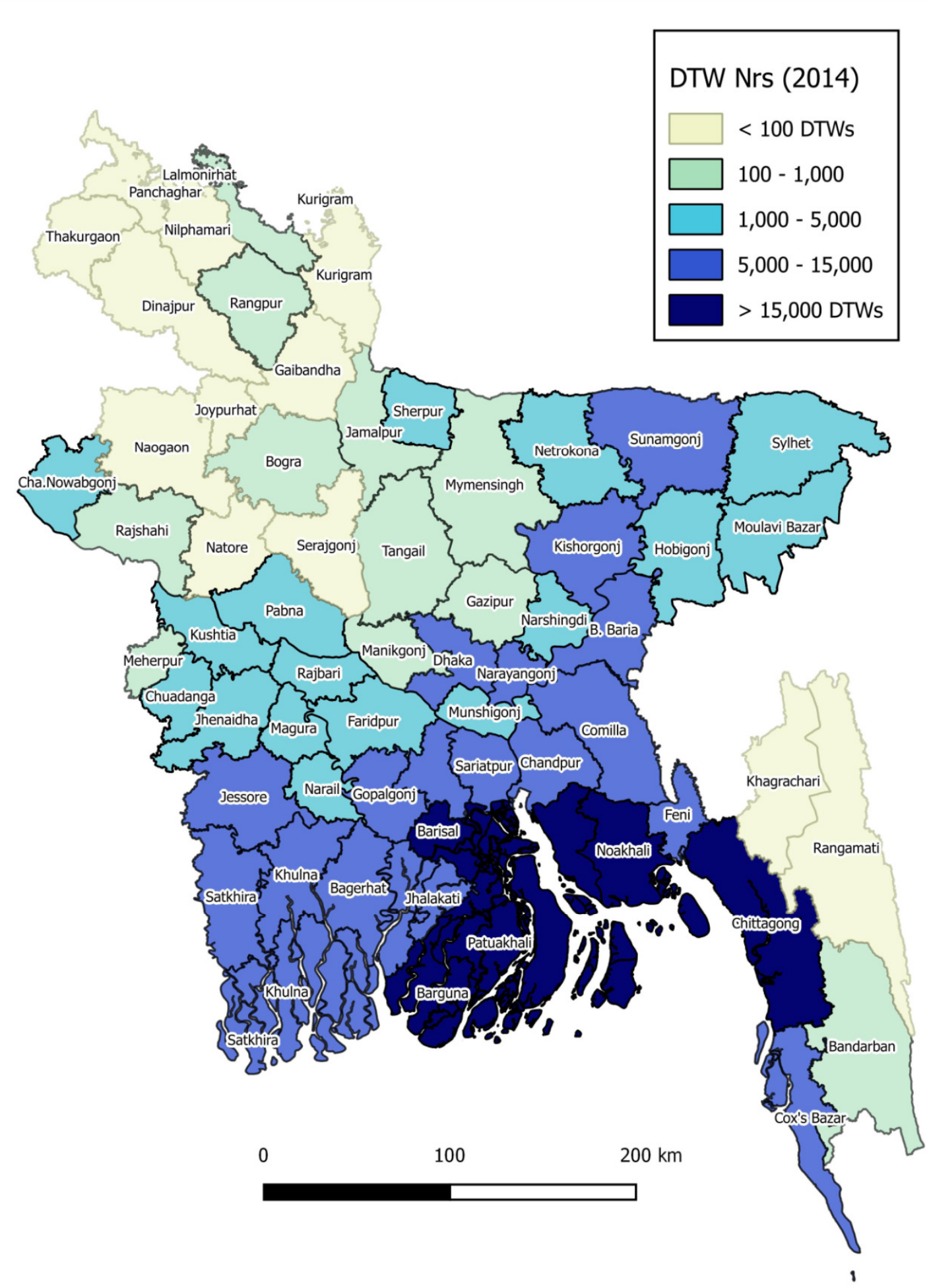

Data: DPHE (unpub.)

Fig S1. Distribution of Deep Tubewells by District. The map shows the total of 330,000 DTWs reported to have been installed by DPHE up to about 2014. It is noted that, in the western, northwestern and north-central areas, not all of these are necessarily deeper than $150 \mathrm{~m}$. 


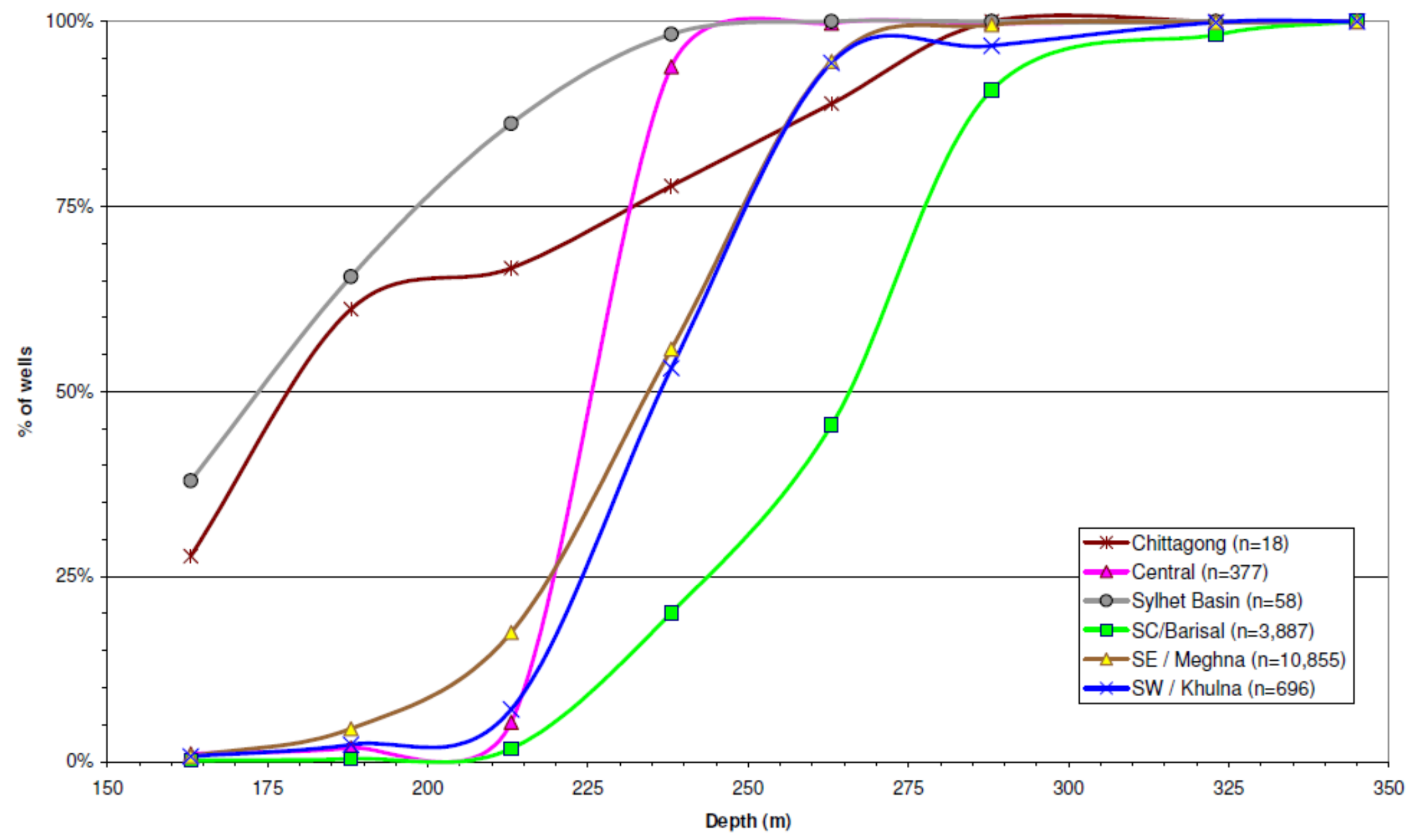

Fig S2. Distribution of DTW Depths in Different Aquifer Units 


\section{S1. Data Sources and Processing}

We compiled a database of $\approx 24,000$ deep wells and piezometers that contains data on well depths, location, water quality and stable-isotopic composition; summary statistics for this database are given in Tables S1 to S4 and Figure S3. The main focus was on chloride, as a measure of salinity, but analyses of As, Fe and Mn are included because they are important determinants of potability. The main data come from two surveys. The first, conducted by Department of Public Health Engineering (DPHE) with assistance from UNICEF, was a completion survey of the Sanitation, Hygiene Education and Water in Bangladesh (SHEWA-B) project in 2012. The second is the Nationwide Water-point Mapping Programme in 2013. Together these surveys cover all rural areas and the vast majority of DTWs installed between 2007 and 2012. Field and analytical methodologies are described in Ravenscroft et al. (2014), but the data analysis herein is new. We use the laboratory water-quality analyses and depth and GPS measurements from randomised quality control. Water was tested in the DPHE Central and Regional laboratories for arsenic, iron and manganese by atomic absorption spectrometry (AAS) and for chloride by argentiometric titration. Other data are collated from older surveys, mostly comprising GPS location, well depth and partial water quality analyses (usually $\mathrm{Cl}, \mathrm{As}, \mathrm{Fe} \pm \mathrm{Mn}$ ), as summarised in Table $\mathrm{S} 2$.

Based on measurements over 13 years from the South-Central aquifer (Ravenscroft et al., 2013) we infer temporal stability of deep water quality measurements over the period of measurements $(1998-2014)$. The short screens $(3-6 \mathrm{~m})$ of DTWs approximate point measurements of water quality and were used to interpolate surfaces of probable $\mathrm{As}, \mathrm{Fe}, \mathrm{Mn}$ and $\mathrm{Cl}$ concentrations (Figures 3 and 4) using the ArcView Spatial Analyst ${ }^{\circledR}$ software. Note that isolated pockets of arsenic contamination exceeding $50 \mu \mathrm{g} / \mathrm{L}$ may be due to incorrect reporting of well depths or construction defects; and similar problems may apply to ${ }^{3} \mathrm{H}$ and ${ }^{14} \mathrm{C}$ determinations.

To understand the timing and mechanisms of recharge, we compiled the available information on stable isotopes $\left({ }^{2} \mathrm{H}\right.$ and $\left.{ }^{18} \mathrm{O}\right)$ and radiocarbon measurements on deep groundwater (SI S4); because of the uncertainties involved in model corrections to ${ }^{14} \mathrm{C}$ ages that arise from 
infiltration processes, and interactions with aquifer carbonates, and also the uncertainties in supporting data, we focus on the ${ }^{14} \mathrm{C}$ activities more than 'corrected' age estimates.

For piezometry (SI S6), we use annual dry-season measurements by DPHE in DTWs and the nearest STW and hydrographs from piezometer nests constructed by the Bangladesh Water Development Board (BWDB). As the relative depth of the deep/shallow pairs is known, the difference in depth to water reveal the direction of vertical flow. Because the topography is so flat and because pre-development monsoonal groundwater levels rose close to ground level, the depth to water below ground level (bgl) approximates the form of the piezometric surface. In such a large database, it is inevitable that errors in reporting, analysis and transcription will be present. For example, pockets of arsenic concentrations $>50 \mu \mathrm{g} / \mathrm{L}$ may be due to incorrect reporting of well depths or defects in well-construction. Furthermore, our data is patchy in its distribution and of varying quality, facts which impair, but do not prevent, recognition of the regional aquifer units we define.

Arsenic Hotspots. There has been much discussion concerning to what extent occurrences of arsenic in deep aquifers are isolated anomalies or inherent features of the aquifer system. The first systematic survey of deep wells (DPHE, 1999) found only 3 out of $>300$ deep wells to exceed 50 $\mathrm{ppb}$. The 3 exceedances were in different regions, although one subsequently turned out to be on the edge of the Sunamganj hotspot. This survey was a driver for the expansion of DTW installation into new areas. Field evidence has confirmed that some deep wells are affected by leaking casing that allows shallow water to enter and sometimes the recorded depths are significantly less than the true depth and may not qualify as deep wells as defined herein (Aggarwal et al., 2000; Ravenscroft et al., 2014; Stahl et al. 2014; Choudhury et al., 2016).

To illustrate the complexity and uncertainty regarding arsenic hotspots in deep aquifers, Fig S4 shows two examples that have been investigated and have differing explanations. Fig S4(a) shows individual deep well analyses in the Sylhet Basin. There are many contaminated wells, especially in 
Sunamganj District; they are clearly grouped, even if their detailed geological association is unclear, as are the uncontaminated well. Separate investigations have shown that the aquifer is heavily contaminated from the water table to at least $300 \mathrm{~m}$, and independent checks have confirmed the essential accuracy of the depth and the chemical analyses (Chowdhury et al., 2010; Ravenscroft et al., 2014). We note that in the area where many wells exceed 50 ppb As national standard, most of the legally compliant wells still exceed the WHO 10 ppb guideline, whereas outside the hotspot the background level is $<10 \mathrm{ppb}$ As. We conclude that the Sunamganj deep aquifer hotspot is a real and extensive natural phenomenon. Fig S4(b), by contrast, shows most of Comilla District in the Southeast where there are also an unexpected number of contaminated deep wells. However, there are significant differences; the background concentration is $<10 \mathrm{ppb}$ As, and the wells exceeding $50 \mathrm{ppb}$ As are less clearly grouped and not spatially associated with groundwater of intermediate (10-50 ppb) As concentration. An audit of fifty apparently contaminated DTWs found that a majority of these wells were $<150 \mathrm{~m}$ deep, and that As contamination was predominantly associated with these shallow wells (Ravenscroft et al., 2014). We conclude that although some arsenic may be present in the deep aquifer, the Comilla 'hotspots' are dominantly the result of construction defects and/or reporting errors. It appears that the conclusions from Comilla apply across the southern and western parts of the country and that the Sylhet Basin is a special case. These deductions demonstrate the importance of quality control and audits in water quality surveys. 
Table S1. Summary of Depth and Chemical Data in the Deep Groundwater Database

\begin{tabular}{|c|c|c|c|c|c|c|c|}
\hline Survey & Depth & $\mathbf{C l}$ & As & $\mathbf{F e}$ & Mn & Aquifer / Region & Note \\
\hline BRGM (2005) & 26 & 26 & 26 & 26 & 26 & Khulna & 1 \\
\hline BRWSSP & 131 & 130 & 60 & 130 & 74 & SE \& Central & 2 \\
\hline BWDB (2013) & 79 & 79 & 20 & 67 & 53 & $\begin{array}{l}\text { SW, SC, SE \& } \\
\text { Chittagong Coast }\end{array}$ & 3 \\
\hline Chowdhury et al. (2012) & 22 & - & 22 & 22 & 22 & Sylhet & 4 \\
\hline Danida (2003) & 20,759 & 20,760 & 13 & 20,612 & - & $\mathrm{SE} \& \mathrm{SC}$ & 5 \\
\hline DPHE $(1999,2001)$ & 175 & 38 & 175 & 174 & 173 & National & 6 \\
\hline Halim et al. (2010) & 46 & 46 & 46 & 46 & 42 & SW, SC \& SE & 7 \\
\hline Hasan et al. (2009) & 32 & 32 & 32 & 32 & 32 & SE / Meghna & 8 \\
\hline Hoque \& Burgess (2012) & 13 & 13 & 13 & 13 & 12 & SE / Meghna & 9 \\
\hline Hoque et al. (2014b) & 39 & 39 & 39 & 39 & 39 & Madhupur (Dhaka) & 10 \\
\hline Hug et al. (2011) & 4 & 4 & 4 & 4 & 4 & Central (Munshiganj) & 11 \\
\hline IWM (2015) & 104 & 104 & 104 & 104 & 104 & National & 12 \\
\hline JICA/UNICEF (2005) & 445 & 445 & 445 & 420 & 340 & Western & 13 \\
\hline McArthur et al. (2016) & 41 & 41 & 41 & 41 & 41 & West Bengal & 14 \\
\hline Mukherjee et al. (2008) & 22 & 22 & 21 & - & - & West Bengal & 15 \\
\hline NAMIC & 2,072 & 2,072 & 1,439 & 2,070 & 35 & SW \& SC & 16 \\
\hline Ravenscroft et al. (2013) & 46 & 46 & 46 & 46 & 46 & SC / Barisal & 17 \\
\hline Ravenscroft et al. (2014) & 324 & 727 & 2,347 & 1,134 & 1,134 & National & 18 \\
\hline VERC/EAWAG & 43 & 37 & 43 & 37 & 37 & SE (Comilla) & 19 \\
\hline Zahid et al. (2008) & 12 & 12 & 12 & 12 & 12 & SE (Kachua) & 20 \\
\hline
\end{tabular}

Notes:

1. BRGM (2005) collected samples at the end of pumping tests or after 30 minutes pumping in production wells; 101 samples were tested at BUET and 10 samples in the BRGM labs in France. Analytical methods are not specified but are understood to have been AAS and ICP respectively.

2. BRWSSP. The ongoing DPHE-World Bank 'Bangladesh Rural Water Supply and Sanitation Project' sampled new test wells immediately after construction and development, usually by a hand 
pump, and sent samples to the nearest DPHE regional laboratories for analysis by AAS and argentometric titration.

3. BWDB (2013) sampled piezometers in the wet and dry seasons. Purging is not specified but physic-chemical parameters were measured before sampling. Water was analysed for As, Fe and Mn by AAS in the BWDB laboratory. The chloride analysis method is not given.

4. Chowdhury et al. (2012) sampled domestic wells which were purged with 40-80 strokes of the hand pump. Unfiltered samples were acidified with $\mathrm{HNO}_{3}$. As and Mn were analysed by ICP-MS, and Fe by flame AAS at Aberdeen University (UK). The LoD for Fe was $0.18 \mathrm{mg} / \mathrm{L}$.

5. Danida-DPHE (2001) provide two data sources: first, samples collected from new production wells that were analysed by AAS at the BUET laboratory in Dhaka and second, unpublished data of analyses from thousands of deep hand tubewells provided by Prof. K.M. Ahmed of Dhaka University, although sampling and analytical details are not known. This is the largest data set, and reports $>20,000 \mathrm{Cl}$ and $\mathrm{Fe}$ measurements, essentially at all project hand tubewells in 5 districts Noakhali. Lakshmipur, Feni, Patuakhali and Barguna). In this data-set, just 13 As concentrations are reported and included in the database. It was unclear whether these were simply not tested in the laboratory (probably because field tests were done) or were below detection limits.

6. DPHE (1999; 2001) collected filtered and acidified samples from domestic wells installed by DPHE and tested for Fe and Mn by ICP-AES. Some water samples were analysed for As by ICP with an LoD of $6 \mu \mathrm{g} / \mathrm{L}$, but most by atomic fluorescence with an LoD of $1 \mu \mathrm{g} / \mathrm{L}$. Chloride was measured by automated colorimetry. Analyses were conducted at BGS laboratories in the UK.

7. Halim et al. (2010) collected samples from domestic wells in HDPP bottles and filtered on site $0.45 \mu \mathrm{m}$ cellulose acetate filters. Samples for metals were stored in polyethylene bottles and acidified with $\mathrm{HNO} 3$ to $\mathrm{pH}<2$. $\mathrm{Cl}$ was measured by Ion chromatography (Metrohm 761 Compact IC). As, Fe and Mn were measured by ICP-MS at Kyushu University (Japan). 
8. Hasan et al. (2009) collected samples through $0.45 \mu \mathrm{m}$ single syringe filters in polyethylene bottles after measuring physic-chemical parameters. Samples for cation and trace element analyses were acidified with suprapure HNO3 $(14 \mathrm{M})$ to bring the $\mathrm{pH}<2$. As, Fe and Mn were analysed by ICP-AES and $\mathrm{Cl}$ by ion chromatography/

9. Hoque and Burgess (2012) sampled domestic and monitoring wells after 30-50 minutes of purging. Samples were filtered and those for cations were acidified to $\mathrm{pH}<2$ with $\mathrm{HNO}$. $\mathrm{Cl}$ was determined using a Dionex DX-120 ion-chromatograph with an IonPac As14 column. Fe, Mn and As were determined by ICP-AES.

10. Hoque et al. (2014b) sampled 44 Dhaka WASA production wells and 17 private wells during their routine operation. Samples were collected in polythene tubes, one acidified with HNO3 and the other not. Fe and Mn were analysed by ICP-AES, As by ICP-MS with a detection limit of $0.1 \mu \mathrm{g} / \mathrm{L}$, and $\mathrm{Cl}$ by ion chromatography.

11. Hug et al. (2011) collected acidified and unacidified filtered samples in polypropylene bottles at tubewells in Munshiganj. Samples for As, Fe and Mn were measured by ICP-MS (Agilent 7500ce) and/or by ICP-OES (Spectro Ciros CCD). Chloride was measured by ion chromatography (761 Compact IC, Metrohm AG).

12. IWM (2015) compile data collected during the drilling of test and production tubewells plus during aquifer tests on the latter during the preparation of a water and sanitation Master Plan for 148 Paurashavas (towns). Water samples were analysed at the Bangladesh University of Engineering and Technology (BUET) by AA for As, Fe and Mn.

13. JICA/UNICEF (2005) collected samples, acidified in the field with $\mathrm{HCl}$, from tubewells and analysed them for As, Fe and Mn by AAS at the Asian Arsenic Network (AAN) laboratory in Jessore on the day of collection. 
14. McArthur et al. (2016) collected acidified and unacidified samples in polythene tubes after purging wells, filtering through $0.45 \mu \mathrm{m}$ membrane filters only when visibly turbid. $\mathrm{Cl}$ and $\mathrm{SO}_{4}$ were determined by ion chromatography, and As and Br by ICP-MS.

15. Mukherjee et al. (2008) purged wells for $>40$ mins before collecting filtered and acidified samples for cation analysis. As was analysed by AAS, and Fe and Mn by ICP-OES.

16. The National Arsenic Mitigation Information Centre (NAMIC) established under the Bangladesh Arsenic Mitigation Water Supply Project (BAMWSP; data provided by Albert Tuinhof of Acacia Water) on samples analysed in the Netherlands.

17. Ravenscroft et al. (2013) collected acidified and unacidified samples from domestic wells in regular use and tested $\mathrm{Cl}$ by ion chromatography, and measured As, Fe and Mn by ICP-MS.

18. Ravenscroft et al. (2014) report data from surveys by Department of Public Health Engineering (DPHE) with assistance from UNICEF; a project completion survey of 21,000 waterpoints the Sanitation, Hygiene Education and Water in Bangladesh (SHEWA-B) project in 2012 and of 150,000 rural water-points installed between 2007 and 2012 from the Nationwide Waterpoint Mapping Programme (NWMP) in 2013. All groundwaters were tested in the field using the EconoQuick ${ }^{\mathrm{TM}}$ kit but only the quality control (QC) samples analysed by laboratory methods are used here. QC samples were analysed in the DPHE regional analyses using Hydride generation AAS for As; flame AAS for Fe and Mn; and argentometric titration.

19. VERC (Village Education and Research Centre) collected samples from DTWS in Manoharganj (SE aquifer) recently constructed (UNICEF funded) project tubewells which were analysed by Dr S. Hug at EAWAG in Switzerland (as per \#11 above).

20. Zahid et al. (2008) sampled existing wells, purging with 40 - 80 strokes of the hand pump before collecting water, which was acidified with $\mathrm{HNO}_{3}$. As, Fe and Mn were analysed by ICP-MS. 
Table S2. Frequency of chloride concentrations in deep aquifers

\begin{tabular}{lccccccc}
\cline { 3 - 7 } \multicolumn{1}{c}{ Aquifer } & \multicolumn{1}{c}{ Chloride, $\mathrm{mg} / \mathrm{L}$} \\
\hline Southwest & 1,351 & $5.6 \%$ & $18.8 \%$ & $46.9 \%$ & $16.8 \%$ & $11.8 \%$ & 365 \\
South-Central & 10,964 & $23.5 \%$ & $37.7 \%$ & $34.0 \%$ & $3.1 \%$ & $1.8 \%$ & 100 \\
Southeast & 11,016 & $33.5 \%$ & $32.6 \%$ & $31.7 \%$ & $2.0 \%$ & $0.2 \%$ & 100 \\
Central & 432 & $1.2 \%$ & $4.4 \%$ & $91.4 \%$ & $2.1 \%$ & $0.9 \%$ & 358 \\
Madhupur & 45 & $88.9 \%$ & $11.1 \%$ & $0 \%$ & $0 \%$ & $0 \%$ & 7 \\
Chittagong Coast & 23 & $61.6 \%$ & $26.9 \%$ & $0 \%$ & $11.5 \%$ & $0 \%$ & 36 \\
Western & 446 & $11.7 \%$ & $41.9 \%$ & $35.9 \%$ & $10.5 \%$ & - & - \\
\hline
\end{tabular}

Note: Laboratory $\mathrm{Cl}$ determinations were not available for the Western Aquifer and so these values were estimated from EC measurements. 


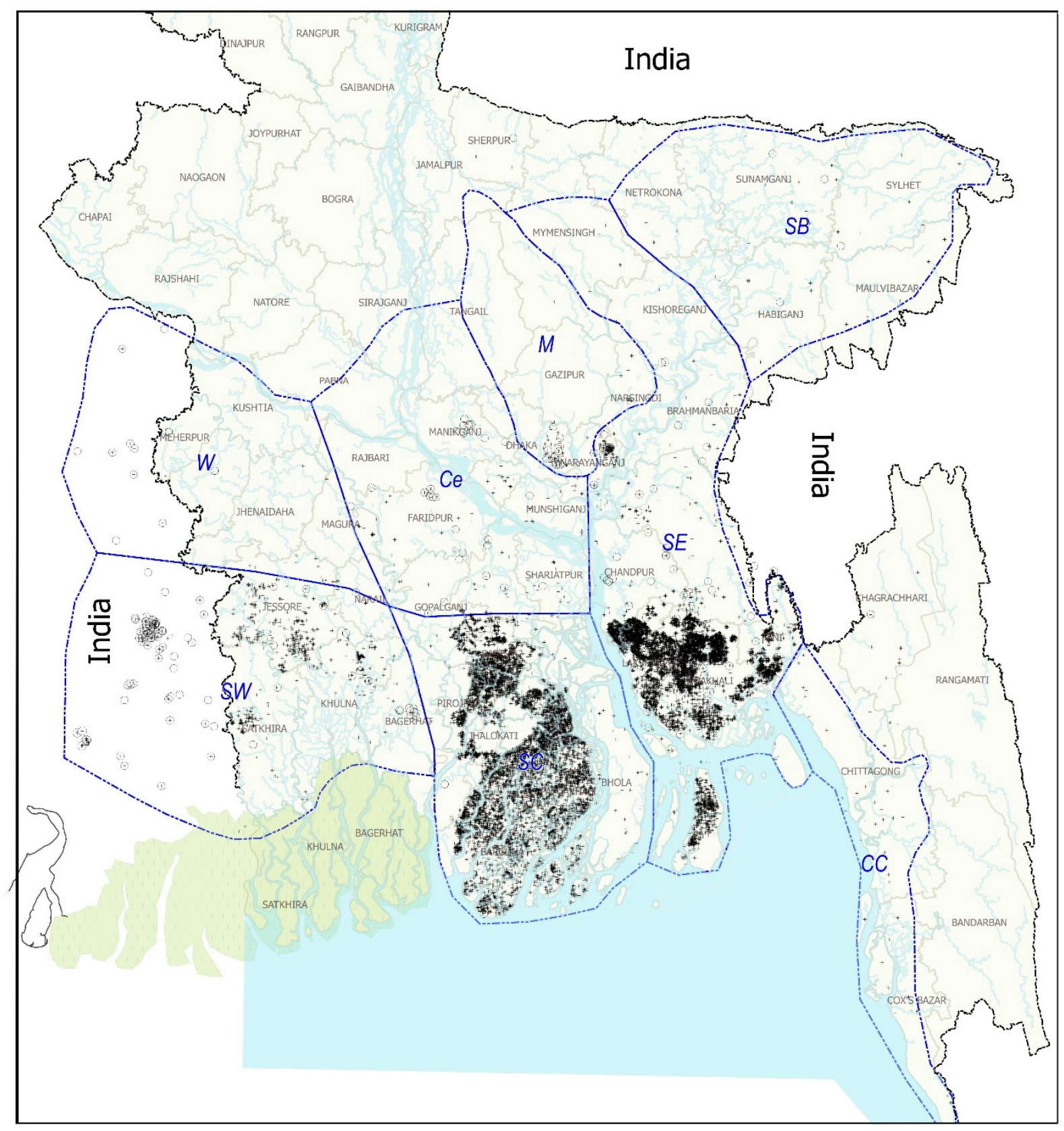

Fig S3. Location of Deep Well Data Points. The map shows the locations of the $>24,000$ georeferenced data points considered, including those subsequently rejected from analysis. Circles indicate sites sampled for isotopic analysis. 

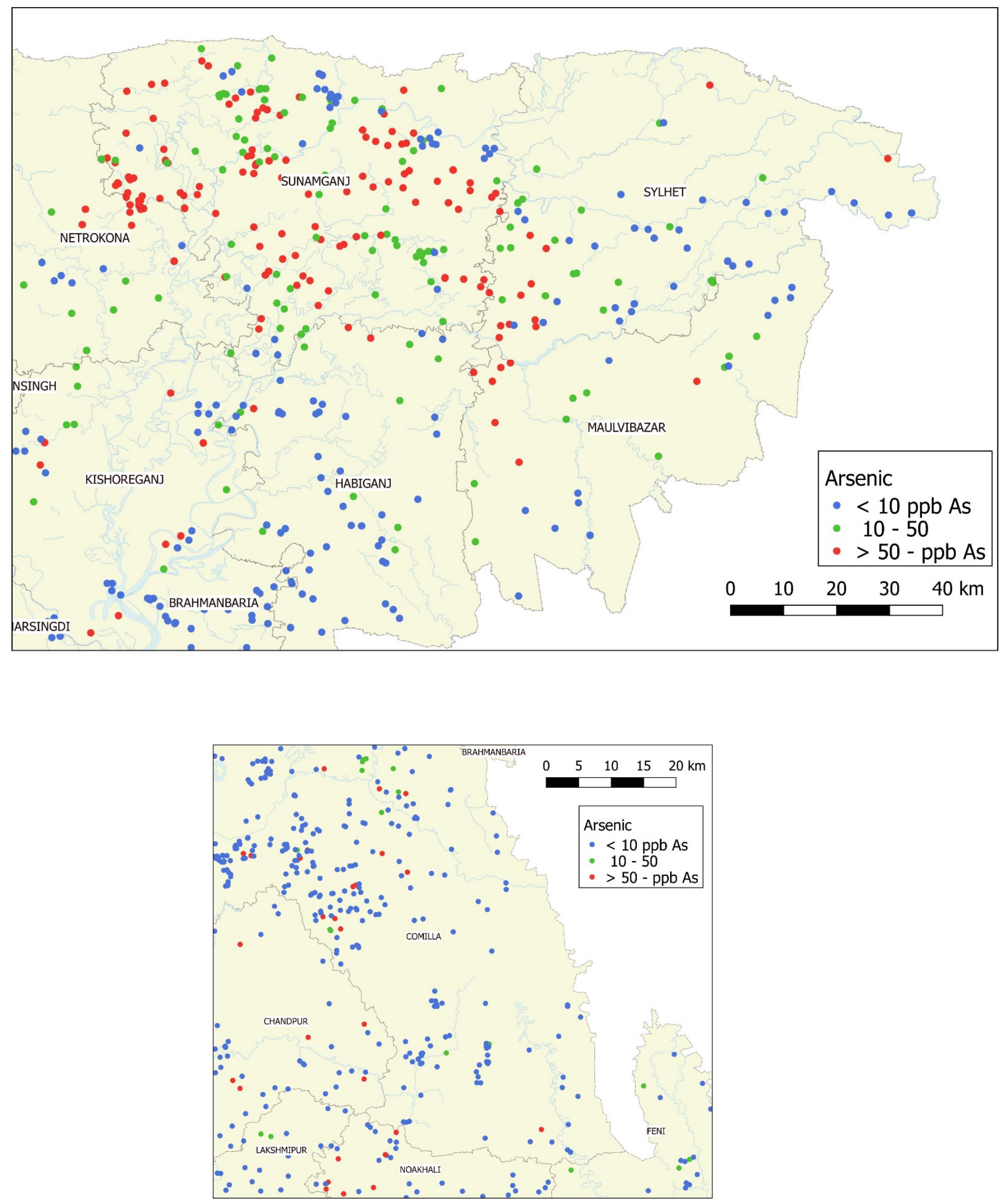

Fig S4. Examples of Arsenic 'Hot Spots' in Deep Aquifers (a) Sunamganj in the Sylhet Basin

Aquifer Unit, and (b) the Comilla in the Southeast Aquifer Unit. 


\section{S2. Deep Aquifer Lithology}

Due to the constraints of the available drilling technology there is a paucity of high quality deep lithological logs, although the report of DPHE-JICA (2002) is a notable exception, and so most interpretations must be based on simple classifications of fine and medium-coarse sand and silty clay. Figure S5 shows some typical lithological logs of deep wells selected from multiple sources (DPHE-DANIDA, 2001; Rus, 1985; DPHE-JICA, 2002) and unpublished logs from the BRWSSP project. Significant sections of brown (oxidised) sand below $100 \mathrm{~m}$ are apparent only in the Central and Chittagong aquifers and, occasionally, in the Southeast Aquifer. Other than close to northern and eastern hills, widespread and substantial thicknesses of gravel are reported only from the Western Aquifer (DPHE-JICA, 2002) although they locally extend into the Southwest Aquifer (Satkhira, personal observation) and probably more extensively along ancient channels of Ganges and Brahmaputra-Jamuna in the Central Aquifer (DPHE-JICA, 2008). In western and northern areas, the existence of deep aquifers may not be recognised due to the difficulty of drilling through gravel horizons that often cannot be penetrated by standard manual technologies (DPHE-JICA, 2008) which may result in a site being misclassified as unsuitable for deep groundwater abstraction whereas actually it requires evaluation using more robust drilling technology. The profiles from the

Central, Western and Southwestern aquifers contain higher proportions of sand; and notwithstanding considerable internal variability in all aquifers, the highest proportions of silt and clay and the greatest separation into multiple aquifers are found in the Southcentral Aquifer.

A large database, though containing less reliable data, is presented by DPHE-JICA (2006). 


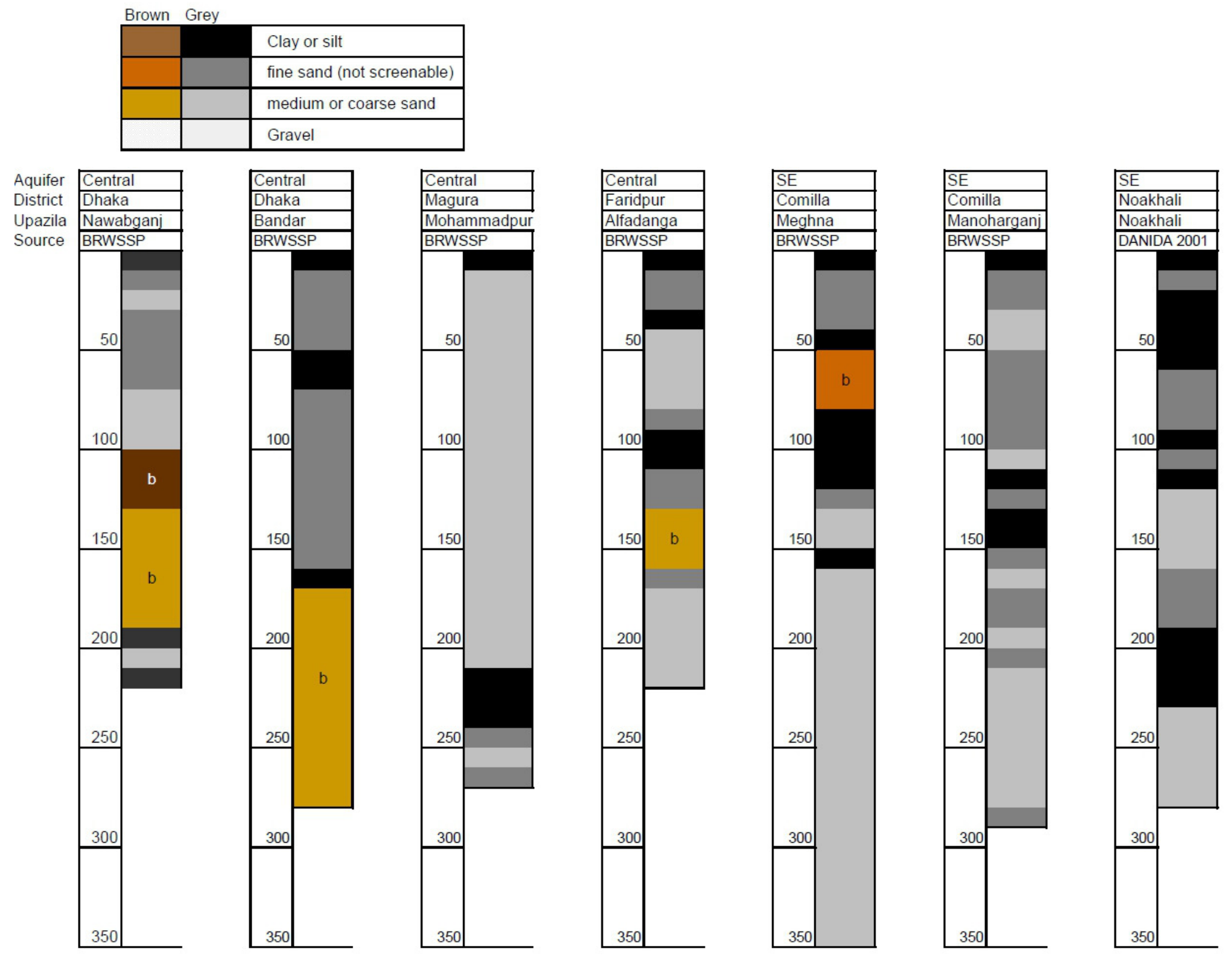




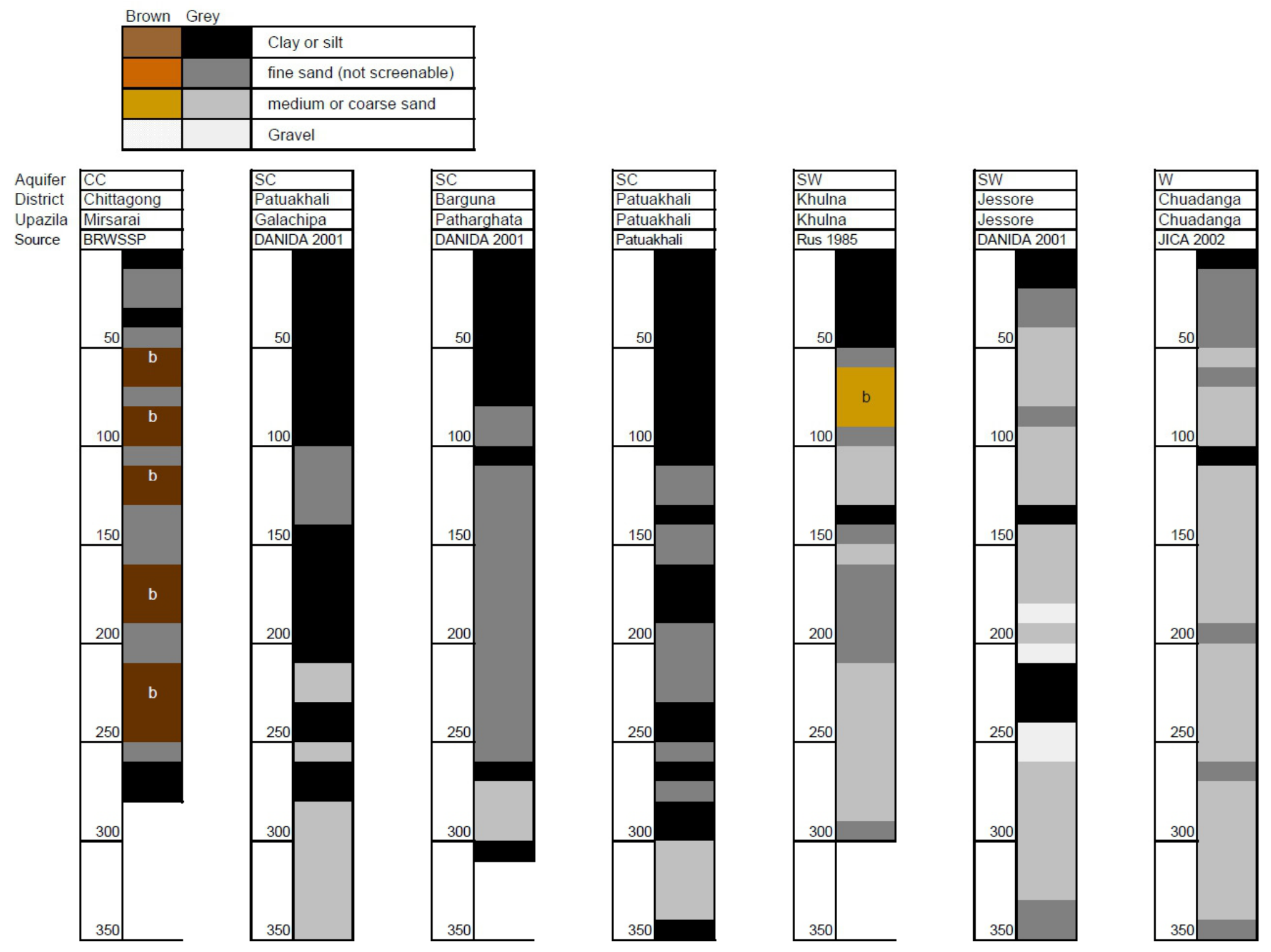

Fig S5. Typical Lithological Logs of Selected DTWs in Different Aquifers 
Locations of the DTWs shown in Fig S5 are listed below:

\begin{tabular}{|l|l|l|r|r|}
\hline District & Upazila & Source & \multicolumn{1}{l|}{ Longitude } & \multicolumn{1}{l|}{ Latitude } \\
\hline Barguna & Patharghata & DANIDA 2001 & 89.87 & 22.04 \\
\hline Chittagong & Mirsarai & BRWSSP & 91.56 & 22.79 \\
\hline Chuadanga & Chuadanga & JICA 2002 & 88.85 & 23.64 \\
\hline Comilla & Manoharganj & BRWSSP & 91.04 & 23.17 \\
\hline Comilla & Meghna & BRWSSP & 90.74 & 23.64 \\
\hline Dhaka & Bandar & BRWSSP & 90.53 & 23.60 \\
\hline Dhaka & Nawabganj & BRWSSP & 90.18 & 23.64 \\
\hline Faridpur & Alfadanga & BRWSSP & 89.68 & 23.25 \\
\hline Jessore & Jessore & DANIDA 2001 & 89.21 & 23.16 \\
\hline Khulna & Khulna & Rus 1985 & 89.55 & 22.84 \\
\hline Magura & Mohammadpur & BRWSSP & 89.58 & 23.41 \\
\hline Noakhali & Noakhali & DANIDA 2001 & 91.10 & 22.88 \\
\hline Patuakhali & Galachipa & DANIDA 2001 & 90.42 & 22.17 \\
\hline Patuakhali & Patuakhali & Patuakhali & 90.34 & 22.36 \\
\hline
\end{tabular}




\section{S3. Isotopic Composition of Deep Groundwater}

The stable isotope analyses included in the database are listed in Table S3. Most deep groundwaters plot on or a little below the Global Meteoric Water Line (GMWL) and the Local Meteoric Water Line (LMWL) from West Bengal (Sengupta \& Sarkar, 2006) indicating that they are derived from local rainfall, with differing degrees of evaporation prior to recharge (Figure 5). The isotopic composition of deep groundwater is also compared to that of modern rivers $\left(\delta^{18} \mathrm{O}-4.5\right.$ to -10$)$.

The radiocarbon analyses of deep groundwater included in the database are listed in Table S4. Only analyses of ${ }^{14} \mathrm{C}$ in DIC are included here. Because there is insufficient information for the consistent application of age-corrections, we concentrate on the more numerous ${ }^{14} \mathrm{C}$ activity (as pmC) measurements. Where we refer to groundwater ages, they are those of the original authors. Radiocarbon measurements may also be confounded by well construction defects (e.g. Aggarwal et al., 2000).

The interpretation of radiocarbon analyses of groundwater in the Bengal Basin is fraught with complications regarding the origin and migration of DOC (e.g. Clark and Fritz, 1997); aquitard diffusion (Sanford, 1997); biogenic and thermogenic methanogenesis-; methane oxidation (e.g. Aravena \& Wassenaar, 1993); soil and sedimentary organic carbon (SOC) that is not carbon-dead, and detrital carbonate dissolved from multiple sources and its variable removal (Clark and Fritz 1997). Although theoretical corrections exist (e.g. ibid., Geyh, 2000; Bethke \& Johnson, 2008) we have too little information to apply them to our data consistently: no single best correction is applicable, so we concentrate on the more numerous ${ }^{14} \mathrm{C}$ activities (as pmC). Where we refer to groundwater ages they are, therefore, those of the original authors and are sensitive to the choice of correction model. For example, the two alternative correction models applied by Hoque and Burgess (2012) reduced apparent ages by 1,000 and 5,000 years. Well construction defects may also confound radiocarbon measurements (e.g. Aggarwal et al., 2000), especially where the true ${ }^{14} \mathrm{C}$ activity is close to the level of detection and may also account for unexpected arsenic-contamination in deep wells (Stahl et al., 2014). 
Deep groundwater has a continuous range of ${ }^{14} \mathrm{C}$ activities from $>100 \%$ to $<10 \% \mathrm{pmC}$, corresponding to ages from the modern to $\geq 18 \mathrm{Ka}$ (Figure 5c). Overall there is a broad correlation between age and depth, indicating vertical penetration of groundwater at least 150-200 m deeper than the corresponding age of the global Quaternary sea level curve (Figure S6). The plot of $\delta^{18} \mathrm{O}$ against ${ }^{14} \mathrm{C}$ activity (Figure 5d) demonstrates the close and complex relationship between the composition and timing of rainfall recharge, and that within aquifer units ${ }^{18} \mathrm{O}$ may serve as a proxy for groundwater age.

\section{Excluded Data}

The surveys listed in Tables S3 and S4 conducted field measurements of $\mathrm{pH}, \mathrm{EC}$, temperature and ORP in the field to try to ensure the integrity of water samples. For wells in routine operation, this should produce reliable samples. However, where wells have not been pumped for a long time, not only this but also conventional purging protocols (e.g. removal of 3 casing volumes could require 1 to 9 hours of pumping) may not be adequate. For example, casing leaks in deep wells are common, and may give rise to the phenomenon known as the 'salt in the morning' well; if combined with a downward hydraulic gradient and the absence of pumping, this could contaminate a potentially large, and practically unknowable, volume of aquifer around the well screen. Also, because cow dung is frequently used as a drilling additive and development of deep wells is almost always deficient; thus, there is a likelihood of solid organic matter remaining outside the screen of an unpumped well, slowly degrading and enriching the passing groundwater in ${ }^{14} \mathrm{C}$. It is also well known that for various reasons, deliberate and accidental, well depths may be misreported. For these and other reasons, certain data points were omitted from the aquifer characterisation process, including:

- $\quad$ The $243 \mathrm{~m}$ deep well at the River Research Institute in Faridpur where Aggarwal et al. (2000) demonstrated the effect of a leaking casing at shallow depth.

- $\quad$ The $293 \mathrm{~m}$ well at a hospital in Manikganj (Ahmed et al., 2010) is suspected to be much less deep because it is $50 \mathrm{~m}$ deeper than any other well, and a hundred metres more than most 
DTWs in the area. It is improbable that such a well would be constructed so differently to the norm, and combined with measurable ${ }^{3} \mathrm{H}$, high Fe and Mn, and being an outlier on a $\delta^{18} \mathrm{O} \%$ - depth plot, this sample appears characteristic of shallow groundwater.

- $\quad$ The depth of the 427 m Khulna Sea Food Industry well of Dray (1982) is not considered credible. It is a hundred metres deeper than other wells and arguably beyond the capacity of drilling technology available at that time. However, considering the local geology, it is probably $>150 \mathrm{~m}$ deep.

- $\quad$ The reported depth $(213 \mathrm{~m})$ of a well plotting in Sherpur District (Majumder et al., 2011) is considered unreliable given our knowledge of wells in that area.

- $\quad 170$ and 300m deep (75 mm internal diameter) investigation wells at Chuadanga (Western Aquifer) installed by JICA (2002) and sampled by Ahmed et al. (2011) approximately five years after installation using either a peristaltic or small jet pump, may have been insufficiently purged.

- $\quad$ Three highly saline waters $(>10,000 \mu \mathrm{S} / \mathrm{cm})$ were retained in the database but omitted from graphs displaying stable isotopes, which only show water samples that are practically 'fresh', i.e. they either comply with legal standards or are actually used for potable purposes. 
Table S3. Stable Isotope Data $\left(\delta^{2} \mathbf{H} \%\right.$ and $\delta^{18} \mathrm{O} \%$ o $)$ in Deep Groundwater

\begin{tabular}{|c|c|c|c|}
\hline Reference & $\mathrm{Nr}$ & Aquifer / Region & Laboratory / Methods \\
\hline Aggarwal et al. (2000) & 7 & SC, SE, SW, Central & $\begin{array}{l}\mathrm{CO}_{2} \text { equilibration, } \mathrm{Cr} \text { reduction, IRMS, IAEA } \\
\text { (Vienna) }\end{array}$ \\
\hline Ahmed et al. (2010) & 18 & Central, SE, SW, Western & $\begin{array}{l}\mathrm{CO}_{2} \text { equilibration, } \mathrm{Cr} \text { reduction, IRMS, IAEA } \\
\text { (Vienna) }\end{array}$ \\
\hline Burgess et al. (2007) & 10 & $\begin{array}{l}\text { Central (Manikganj); Western } \\
\text { (Gangni) }\end{array}$ & Not stated \\
\hline Darling et al. (2002 & 7 & Madhupur (Dhaka City) & Not stated \\
\hline DPHE $(1999,2001)$ & 26 & $\begin{array}{l}\text { Central (Faridpur); SE } \\
\text { (Lakshmipur) }\end{array}$ & BGS lab (UK) by MS \\
\hline Dray (1982) & 13 & SC, SW, Chittagong coast & IAEA, Vienna (assumed) \\
\hline $\begin{array}{l}\text { Hoque\& Burgess } \\
(2012)\end{array}$ & 13 & SE & $\begin{array}{l}\text { BGS lab (UK) with VG Micromass 602E or } \\
\text { Optima MS }\end{array}$ \\
\hline Hoque et al. (2014) & 7 & Madhupur (Dhaka City) & Picarro WSCRDS laser instrument \\
\hline Majumder et al. (2011) & 102 & $\begin{array}{l}\text { Central, SC, SE, SW, Sylhet } \\
\text { Basin }\end{array}$ & $\begin{array}{l}\mathrm{CO}_{2} \text { equilibration, } \mathrm{Cr} \text { reduction, thermo- } \\
\text { electron delta-S MS (Japan) }\end{array}$ \\
\hline McArthur et al. (2016) & 36 & West Bengal & $\begin{array}{l}\text { Picarro WSCRDS laser instrument } 134 \\
\text { calibrated against standards USGS } 46 \text { and } 48 .\end{array}$ \\
\hline Mihajlov et al. (2016) & 15 & Madhupur (Araihazar) & $\begin{array}{l}\text { Cavity ringdown laser spectrometer at } \\
\text { Lamont-Doherty Earth Observatory (L2130-i } \\
\text { Isotopic H2O, Picarro, Santa Clara, CA) }\end{array}$ \\
\hline Mukherjee et al. (2008) & 31 & West Bengal & U. Kentucky lab; \\
\hline Sengupta et al. (2008) & 3 & West Bengal & $\begin{array}{l}\text { Gas-source mass spectrometry at IIT } \\
\text { Kharagpur }\end{array}$ \\
\hline Total & 288 & & \\
\hline
\end{tabular}

Notes: IRMS - isotope ratio mass spectrometer.

Notes: MS - mass spectrometer. 
Table S4. Radiocarbon Measurements in Deep Groundwater

\begin{tabular}{|l|l|l|l|}
\hline Reference & Nr & Deep Aquifer & Laboratory / Methods / Notes \\
\hline Aggarwal et al. (2000) & 28 & SC, SE, Central, Western & $\begin{array}{l}\text { Direct absorption, low level liquid } \\
\text { scintillation counter, IAEA (Vienna). } \\
\text { No specific age corrections reported. }\end{array}$ \\
\hline Ahmed et al. (2010) & 32 & SE, SW, Central, Western & $\begin{array}{l}\text { Direct absorption, low level liquid } \\
\text { scintillation counter, IAEA (Vienna). } \\
\text { No specific age corrections reported. }\end{array}$ \\
\hline Dray (1982) & 12 & SC, SW, Chittagong Coast & IAEA, Vienna (assumed) \\
\hline Hoque \& Burgess (2012) & 18 & SE & $\begin{array}{l}\text { IsoTrace lab, U. Toronto and U. } \\
\text { Waterloo; Accelerator MS }\end{array}$ \\
\hline Majumder et al. (2011) & 10 & National & $\begin{array}{l}\text { BaCO3 precipitates were freeze-dried } \\
\text { for 24 hr and sent to Nagoya University } \\
\text { for analysis by a HVE 14C-AMS } \\
\text { (model 4130). }\end{array}$ \\
\hline Mihajlov et al. (2016) & 15 & Madhupur (Araihazar) & $\begin{array}{l}\text { Samples preserved with HgCl2; } \\
\text { analysed at the National Ocean Science } \\
\text { Accelerator Mass Spectrometer facility } \\
\text { at the Woods Hole Oceanographic } \\
\text { Institution }\end{array}$ \\
\hline von Brömssen et al. (2014) & 6 & SE (Matlab) & $\begin{array}{l}\text { U. Lund lab. (Sweden); details not } \\
\text { specified; }{ }^{13} \text { C age correction but details } \\
\text { not given. }\end{array}$ \\
\hline
\end{tabular}




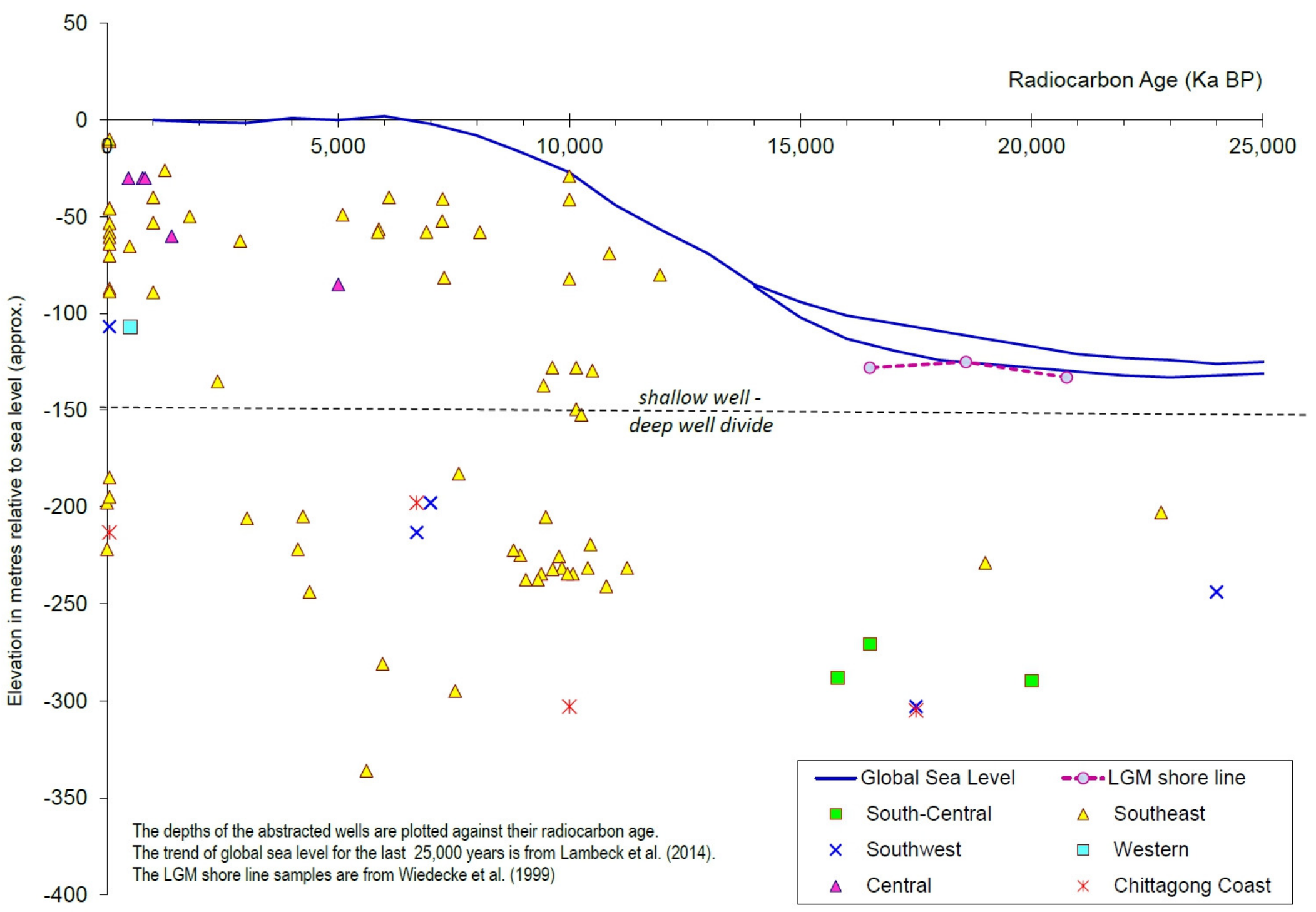

Fig S6. Groundwater Ages as a Function of Depth. The ages are those of the original authors. Note the correction methods are those of the original authors and may not be consistent. Sea-levels 1 and 2 represent limiting trends from different authors. 


\section{S4. Water Level Information on the Deep Aquifer}

We draw on routine monitoring of depth to water in operating DTWs, ad hoc project monitoring of project piezometer nests detailed below, and systematic monitoring from piezometer nests constructed by the Bangladesh Water Development Board in the south of the country (BWDB, 2013).

Hydrographs show three types of response: (Type 1) a northern group that are basically parallel with no significant vertical gradient; (Type 2) a central group where significant downward gradients develop in the dry season but levels converge during the monsoon; and (Type 3) a southern group where deep water levels are typically $2-4$ m deeper all year round, and generally but not necessarily parallel.

Where available, DPHE measures the deepest dry-season depth-to-water in one DTW and one STW in each union each year. The reported value is specified to be the deepest of three measurements made in March and April. Because the topography is so flat and pre-development monsoon water levels rose close to ground level, the depth to water below ground level both indicates the operability of suction mode pumps and approximates the form of the piezometric surface. Some of the reportedly deep wells by DPHE are suspected to be $<150 \mathrm{~m}$ deep and have been excluded from the data set used to calculate depths-to-water in deep aquifers (Figure S7). However, the relative depth of the well pairs is not doubted, and experience suggests the difference in depth to water correctly indicates the direction of hydraulic gradients between deep and shallow aquifers and so was included in Figure 6. At the 30 BWDB piezometer nests, depth, elevation, lithology and water quality are reliably known, however, these locations are mostly urban and so should be interpolated with caution.

The maximum depth to water in DTWs in the dry seasons of the years 2012 to 2014 is shown in Figure S7. Three years' data were combined to give a better regional picture of the form of the piezometric surface. 
The following groups have conducted ad hoc monitoring of deep water levels:

- DPHE-JICA (2002) monitored pairs of piezometer nests, screened at 50, 100, 150 and 300 $\mathrm{m}$ in Chuadanga, Jhenaidah and Jessore municipalities (Western aquifer) for 12 months. The sites are geologically similar, being dominantly sandy with few aquitards and gravelly horizons between 100 and $200 \mathrm{~m}$.

- DPHE (2001) monitored piezometer nests between 10 and $150 \mathrm{~m}$ at Faridpur (Central aquifer) and Lakshmipur (SE aquifer) and monitored them for 12 months in $1999-2000$. At Faridpur, water levels were coincident through the year; but at Lakshmipur there was a small downward gradient from 10 to $50 \mathrm{~m}$ but the level at $150 \mathrm{~m}$ was consistently about 1.5 $\mathrm{m}$ lower at all times.

- von Brömssen et al. (2014) monitored 3 to 5 piezometers at depths of $14-238 \mathrm{~m}$ at 10 sites in Matlab Upazila of Chandpur District (SE aquifer) in 2009-10.

- DPHE and the Institute of Water Modelling (IWM) monitored multi-level piezometers at 12 sites west of Khulna District (SW aquifer) in 2012. IWM and DPHE measured water levels and salinity in nested piezometers located a few tens of kilometres southwest of Khulna City; many of these piezometers are completed in brackish groundwater and therefore represent conditions in the distal part of the SW Aquifer rather than the bulk of the exploited aquifer - the study area lies only $12-15 \mathrm{~km}$ north of the Sundarban mangrove forest. The IWM-DPHE water level measurements were adjusted for density to give correct vertical head gradients using Equation 12 of Post et al. (2007). Fluid density was estimated from the average electrical conductivity (EC) assuming densities of 1.000 for fresh water and 1.025 $\mathrm{kg} / \mathrm{L}$ for sea water with an $\mathrm{EC}$ of $50,000 \mu \mathrm{S} / \mathrm{cm}$. No correction for temperature was applied. Density corrected are plotted as hydrographs in Figure S8. Many of the hydrographs display unlagged, parallel trends that suggest mechanical loading plays an important role. In the northernmost piezometer nest (Dumuria North), where the groundwater is fresh to 
marginally brackish at all depths, the flow direction is downward. At the other four piezometer nests, the deep piezometers are all screened in very brackish water $(\geq 10,000$ $\mu \mathrm{S} / \mathrm{cm})$. One nest shows a consistently upward gradient, one is mostly downward, and the others display temporally variable gradients. This pattern differs from the dominantly downward gradients recorded in the BWDB nests, which are generally further inland, and suggests that the piezometric surface of the SW deep aquifer is declining due to pumping. This is supported by a plot of density-corrected freshwater head against EC (Figure S9) which shows a strong association between heads above sea level and increasing salinity (but not well depth). This is contrary to what would be expected in an undisturbed condition, where head would be expected to show an inverse between (decreasing) head and (increasing) salinity moving towards the coast. The most likely interpretation of the higher heads in saline zones is that these sections are unpumped and these heads represent the residual pre-development hydraulic gradient. If correct, the difference between the (freshwater) heads in the fresh and saline zones would be a minimum estimate of the unmonitored pumping-induced lowering of the piezometric surface. Whether, and at what rate, this brackish water is migrating inland is unknown.

Widespread downward hydraulic gradients in the distal parts of the basin have at least four possible explanations that are not mutually exclusive:

(i) The simplest explanation would be deep groundwater abstraction, but there is poor spatial correlation between deep abstraction, estimated from tubewell numbers (Figure S1), and the magnitude of drawdown in the deep aquifers; although pumping at Dhaka City is a special case where the cone of depression from thousands of deep and shallow municipal and industrial wells has drawn down water levels by up to $60 \mathrm{~m}$ in the city (Hoque et al., 2007; Knappett et al., 2016) and may have affected water deep wells for a few tens of kilometres around the city. 
(ii) Substantial submarine groundwater discharge (SGD) beyond the edge of the subaqueous delta shelf break, which could generate deep underflow, has been inferred from hydrochemical data (Moore, 1997; Basu et al., 2001; Dowling Poreda \& Basu, 2003) but appears inconsistent with the hydraulic regime (e.g. Harvey, 2002; Michael \& Voss, 2009b). The inferred inland flow in the SC and SW aquifers favours rejecting deep SGD, although exchange of shallow groundwater with tidal surface waters is likely.

(iii) Natural gas abstraction reduces upward pressure and in other basins has caused land subsidence (e.g. Kreitler, 1989). Bangladesh's gas fields are mostly located close to the eastern anticlinal hills, where naturally over-pressured horizons occur at depths of about $3 \mathrm{~km}$ (Curiale, Covington, Shamsuddin, Morelos \& Shamsuddin, 2002; Roy, Ray \& Biswas, 2010). There is currently no evidence whether this effect is significant.

(iv) Under-pressure due to the incomplete adjustment to post-LGM sea level rise was advanced to explain the 'hollow aquifers' in West Africa (Dieng, Ledoux \& De Marsily, 1990). The plausibility of such disequilibrium in the Bengal Basin can be tested using the equation of Rousseau-Gueutin et al., 2013) to calculate the time $\left(t_{\mathrm{NE}}\right)$ to attain $95 \%$ of the steady state in a confined - unconfined aquifer after a sudden change in base level:

$$
\begin{gathered}
t_{\mathrm{NE}}=\quad \underline{3 \mathrm{~S}}_{\underline{\mathrm{L}}} \underline{\mathrm{L}} \underline{\mathrm{u}} \cdot\left(\mathrm{L}_{\underline{\mathrm{c}}}+0.5 \underline{\mathrm{L}_{\underline{u}}}\right) \\
\mathrm{T}
\end{gathered}
$$

Where $S_{u}$ is the unconfined storage coefficient, $L_{c}$ and $L_{u}$ are the lengths of the confined and unconfined sections of the aquifer and $\mathrm{T}$ its transmissivity. Assigning values for $\mathrm{S}_{\mathrm{u}}, \mathrm{L}_{\mathrm{c}}, \mathrm{L}_{\mathrm{u}}$ and $\mathrm{T}$ of $0.1-0.2,250 \mathrm{~km}, 150 \mathrm{~km}$, and $1000-5000 \mathrm{~m}^{2} / \mathrm{d}$ as typical of the basin (e.g. Ravenscroft, 2003), this respectively yields time constants of 8 to $80 \mathrm{Ka}$. These estimates range from long before the LGM to near the time (c. $7 \mathrm{ka}$ ) when global sea approached its present level. Therefore, it is conceivable that memory of Late Pleistocene sea levels still affects the deep aquifers. 
The inference of inland flow in the SW and SC aquifers suggests the possibility of compaction-induced flow (Kooi, 1999; Kooi \& Groen, 2003) resulting from the rapid monotonic loading of the deep aquifers by water and sediment during the post-LGM transgression that produced offshore overpressures that have not yet dissipated.

An anomalous area of upward gradients in central Bhola Island coincides with methane-rich artesian flows which have sustained domestic cooking stoves for several decades (Figure S10). The gas-producing DTWs differ from STWS that produce biogenic methane and are associated with high Fe and Mn concentrations (Ahmed, Hoque, Hasan, Ravenscroft, \& Chowdhury, 1998), and have higher salinity (EC 2,910 vs. $1,140 \mu \mathrm{S} / \mathrm{cm})$ and temperature $\left(28.2\right.$ vs. $\left.27.7^{\circ} \mathrm{C}\right)$ than other DTWs in the same area and are not enriched in Fe and Mn. The area on Bhola Island with upward gradients is close to the commercial gas field at Shahbazpur, and these phenomena may have a common cause in the buoyant rise of water saturated in thermogenic gases. It may be significant that the deep gas discharges on Bhola Island align with the thrust fault noted above. A few methaneproducing DTWs have been recorded further west in Pirojpur and Jhalokati districts (Figure S7), but not from any other deep aquifer. 


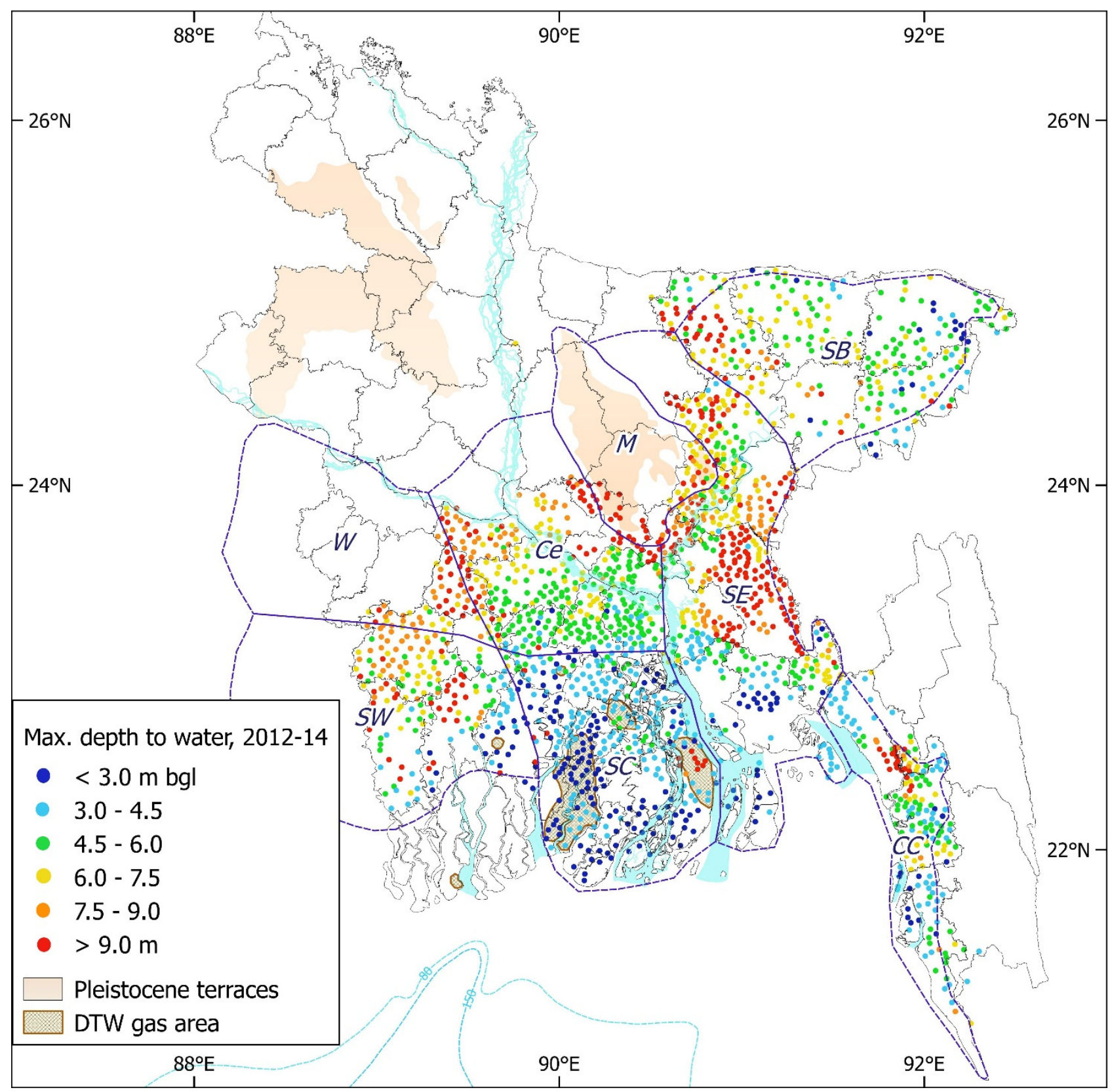

Fig S7. Maximum depth to water in DPHE DTWs 2012 - 2014. In theory, levels are measured three times during March and April of each year, and the deepest value is recorded in a database. Only wells accepted here as $>150 \mathrm{~m}$ deep are included. The areas in the South-Central Aquifer in which methane gas has been recorded in DTWs are also shown. 


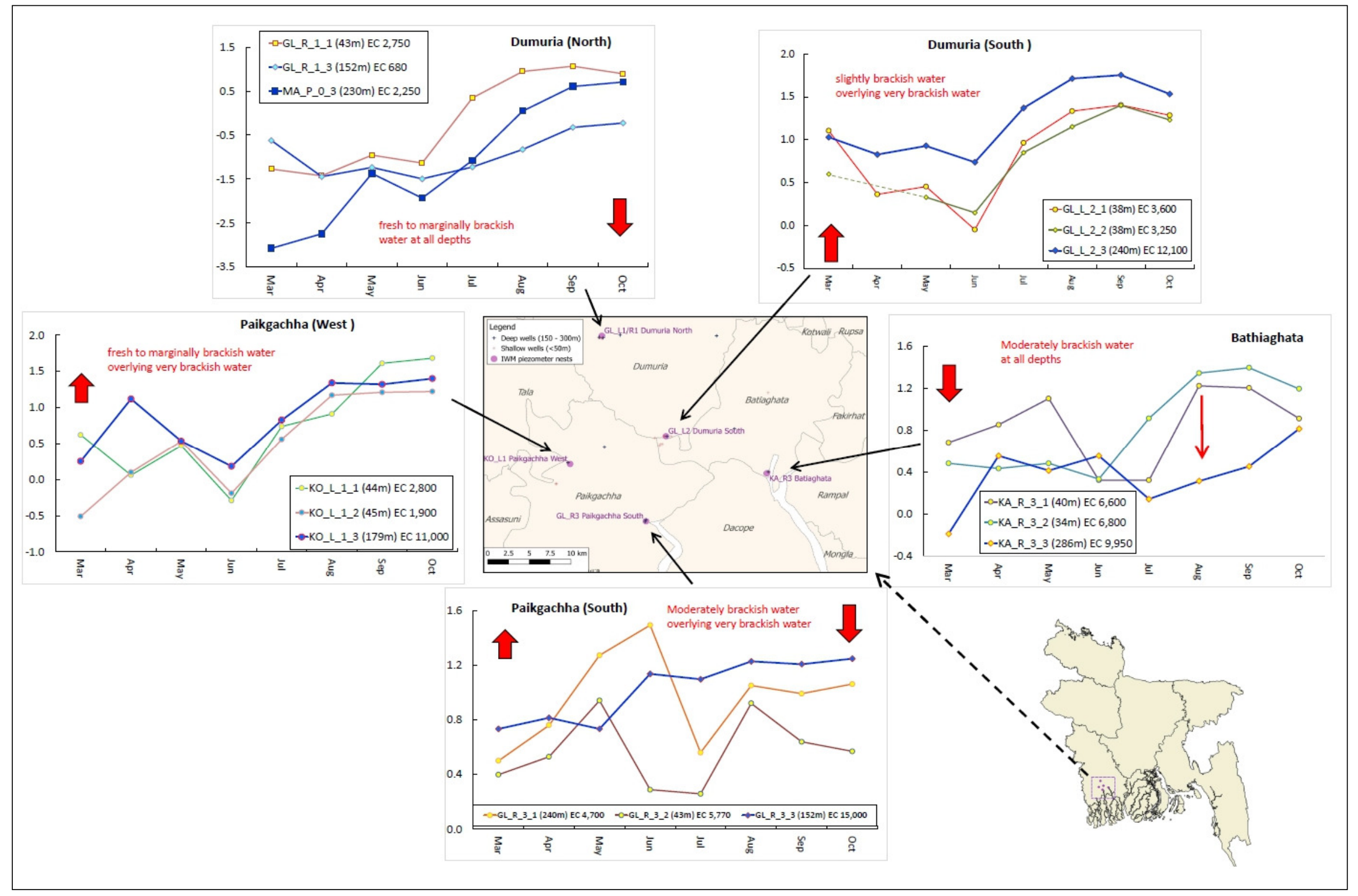


Fig S8. Hydrographs of Density Adjusted Freshwater Head at Piezometer IWM-DPHE Nests in the SW Aquifer. Data from IWM/DPHE. Water levels to FWH for vertical gradients component using Equation 12 of Post et al. (2007) for density estimated from EC. Heavy, dark blue line identify piezometers screened at $>150 \mathrm{~m}$. Markers on the lines indicate whether the groundwater is fresh $(<2 \mathrm{~K} \mu \mathrm{S} / \mathrm{cm}=$ light blue $)$; moderately brackish $(>2$ $10 \mathrm{~K}=$ yellow $)$ or very brackish to highly saline $(>10 \mathrm{~K} \mu \mathrm{S} / \mathrm{cm}=$ red). Red block arrows show the direction(s) of groundwater flow in real world (i.e. up or down) terms. 


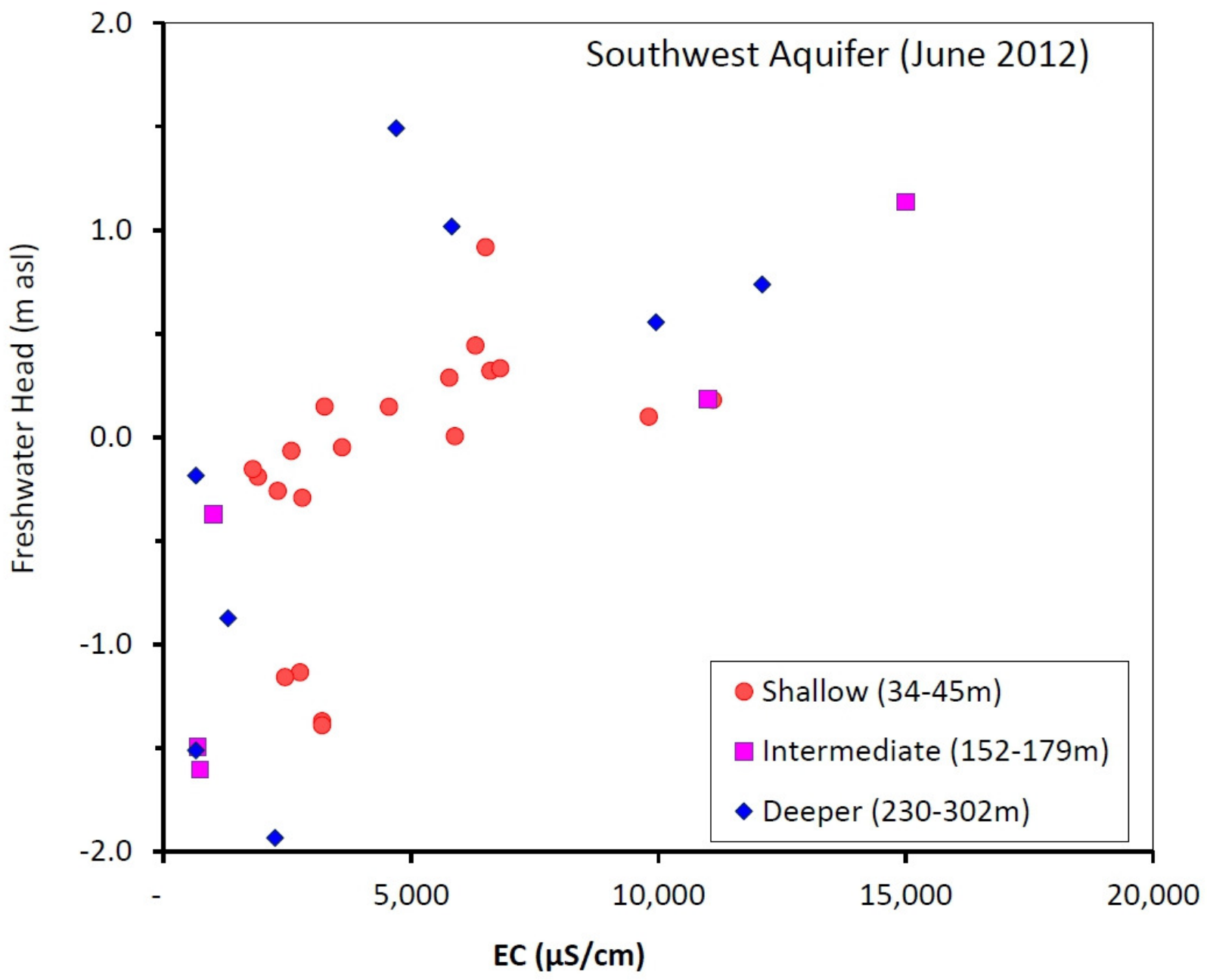

Fig. S9 Plot of Density Adjusted Freshwater Head against salinity (as EC). The points represent one sampling round (June 2012) of the data plotted in Fig S8. 


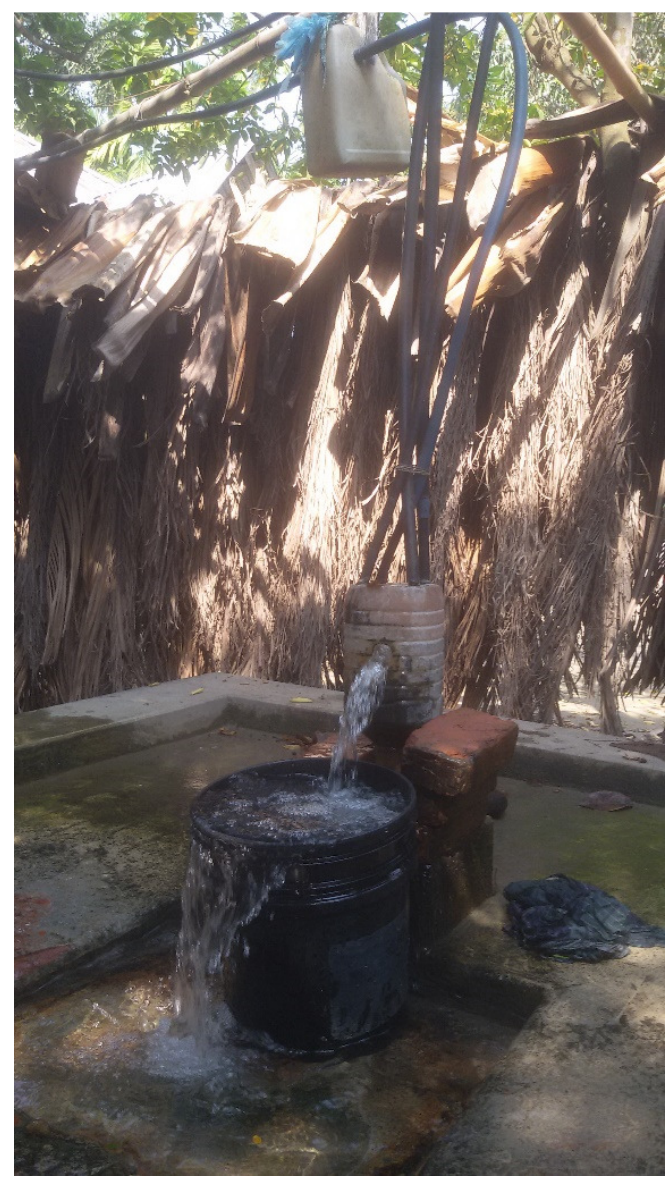

Fig. S10. Photograph of flowing artesian well on Bhola Island. Flow is accompanied by the copious release of methane which is captured and used for cooking by several households. The gas is collected through an upturned water container discharging water through a side pipe while gas is removed through four hoses. The plastic jerry-can serves as a water condenser. Photograph courtesy of Professor Kazi Matin Ahmed, Department of Geology, Dhaka University. 


\section{S5. Additional Information on the South-Central Deep Aquifer}

Indirect evidence for the offshore extension of the South-Central deep aquifer comes from Wiedecke et al. (1999) who located an LGM shoreline at a depth of $130 \mathrm{~m}$ and dated at 16.5 $20.8 \mathrm{Ka}$, about $75 \mathrm{~km}$ south of the current shoreline at about $90^{\circ} \mathrm{E}$ and about $50 \mathrm{~km}$ east of the Swatch of No Ground (Figure S11). Approaching the corresponding section of the modern shoreline, the SC aquifer is typically $230-280 \mathrm{~m} \mathrm{bgl}$ and thus at the LGM the aquifer would have been covered by at least $100 \mathrm{~m}$ of sediment, and therefore unlikely to discharge to the ocean until $150-200 \mathrm{~km}$ beyond the present coastline. Interpolating between the coastal aquifer geometry and offshore seismic interpretations (Figure S11) suggests that the SC aquifers are lateral equivalents of Forced Regression System Tracts (FRST) 10 to 14 of Hübscher \& Spieß (2005). If they are true correlates, it implies deposition between 180 and $460 \mathrm{Ka}$, and that any potential low-stand discharge zone would have been covered by deposits of FRST 6 during the LGM. Applying the facies models of Wilson and Goodbred (2015) suggest these sediments would be tidal delta plain deposits comprising subaqueous delta muds succeeded by fluvial-tidal channel medium-fine sands, followed in turn by laminated fine sand and silt. Channel sands aquifers would be both less permeable that those of the fluvial fan delta, less laterally extensive and more tightly confined. The thickness and permeability of the sand bodies would tend to reduce towards the coast and be interbedded with occasional peat horizons (Wilson and Goodbred, 2015). Even adjusting for post-LGM subsidence rates of $0.4-2 \mathrm{~mm} / \mathrm{yr}$ (Goodbred \& Kuehl, 2000a,b; Hübscher \& Spieß, 2005), or 5 - 40m over 20 $\mathrm{Ka}$, would not restore the SC deep aquifers to a depth where substantial submarine discharge would be credible. This further supports the view that the SC deep aquifer was strongly confined throughout the last $120 \mathrm{Ka}$ and perhaps longer. 


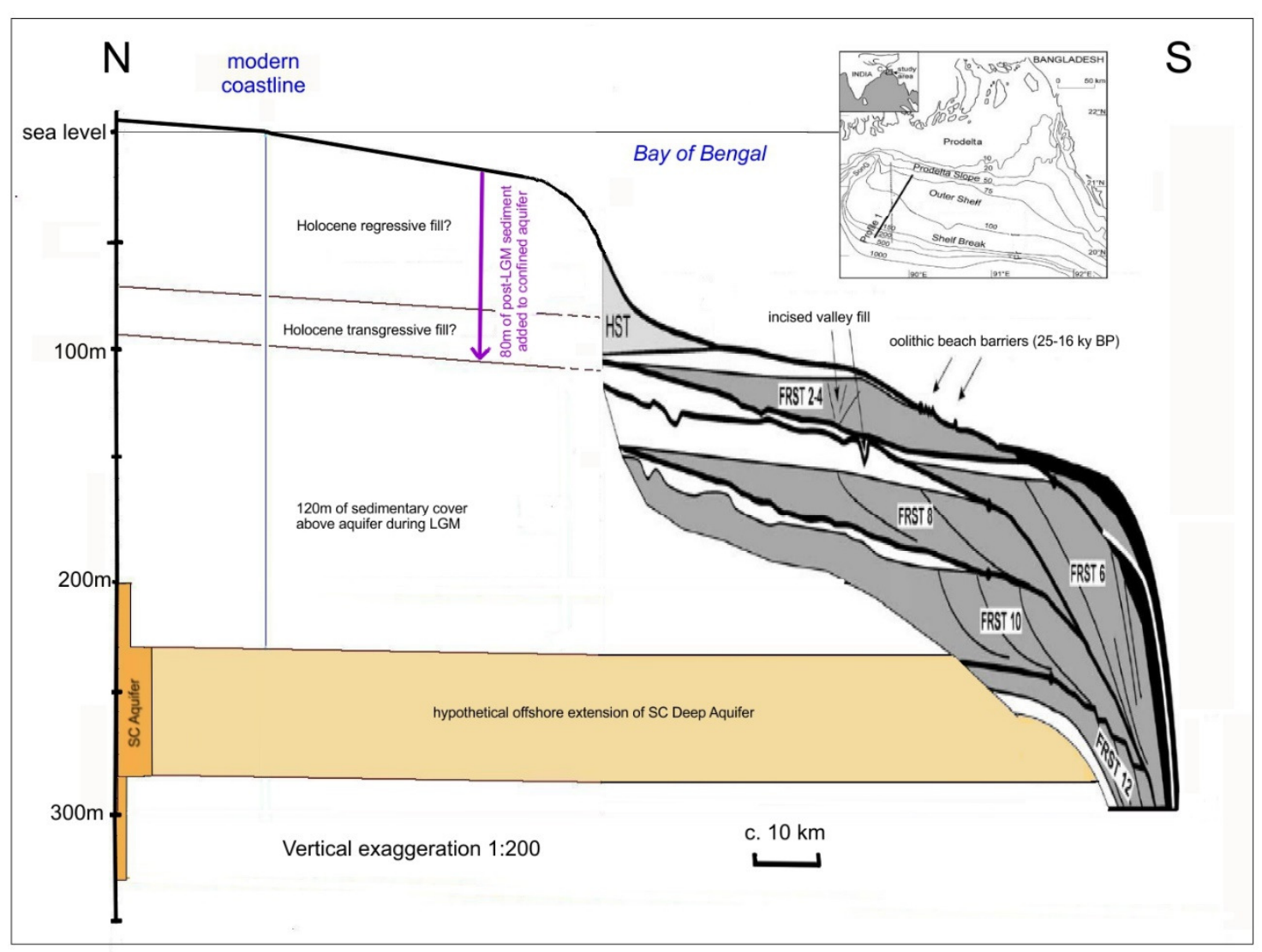

Fig S11 Offshore projection of the SC Deep Aquifer. The section hypotheses the potential continuity between the SC deep aquifer near the coast (range $200-330 \mathrm{~m}$ but principally 230 -280m) with the offshore seismic profile 1 of Hubscher \& Spieß (2005), assuming no change in facies and an offshore dip equal to the present inland surface gradient.

Lateral chemical gradients in groundwater from the SC deep aquifer were interpreted to result from ion exchange associated with flushing of an aquifer that once contained saline water (Ravenscroft \& McArthur, 2004). Figure S12 updates the distribution of deep boron (B) and compares it with the distribution of chloride. The E-W gradients of increasing B and Na exceed what can be explained by seawater mixing and confirm that additional $\mathrm{B}$ is derived from ion-exchange as freshwater flushes more saline water from the aquifer. The highest concentrations of B occur in the far west at depths of $>250 \mathrm{~m}$, along a lineament that corresponds to the inland extension of the Swatch of No Ground. Since the SC aquifer is being flushed by water recharged during the LGM or older, the original saline intrusion event occurred earlier, possibly during the high stand at about $125 \mathrm{Ka}$. This 
implies that the SC aquifer did not discharge freely to the Bay of Bengal during the LGM. The pocket of elevated $\mathrm{Cl}$ on the eastern edge of the aquifer coincides with an area of methane gas discharge and is not related to the process of regional flushing; the enrichment on the western edge is not connected to gas.
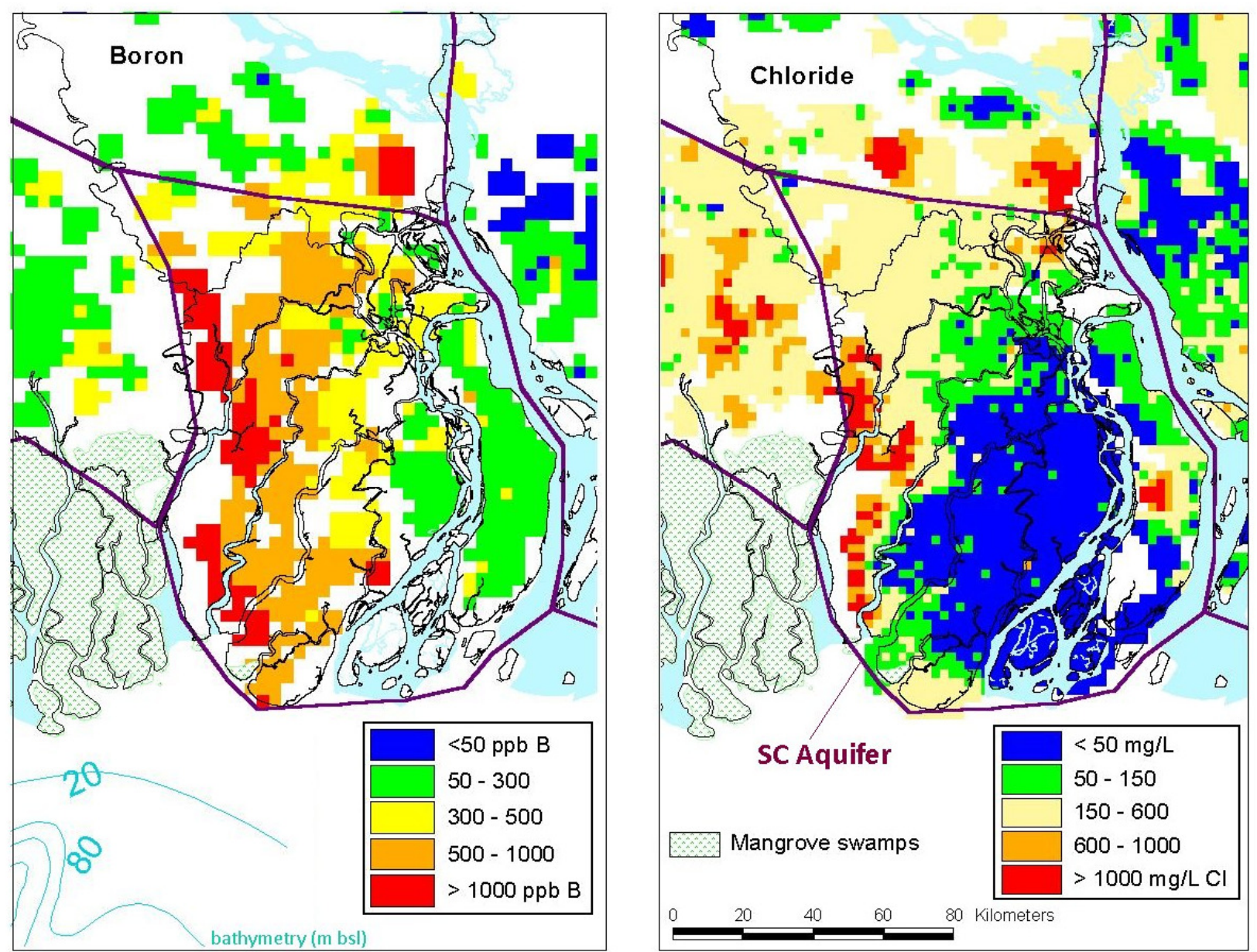

Fig S12. Maps of (a) boron and (b) chloride distribution in and around the SC deep aquifer 


\section{Additional References}

Ahmed, K.M., Hoque, M., Hasan, M.K., Ravenscroft, P. \& Chowdhury, L.R. (1998). Occurrence and origin of water well methane gas in Bangladesh. Journal of the Geological Society of India, 51, $697-708$.

Ahmed, N., Newman, B.D., Aggarwal, P.K., Majumder, R.K., Halim, M.A., Rasul, M.G. \& Hossain, S. (2010). Hydrochemical and Isotopic investigations of groundwater in Bagerhat, Chuadanga, Chapai Nawabganj, Chandpur and Manikganj Paurashava areas. International Atomic Energy Agency (Vienna) and Bangladesh Atomic Energy Commission.

Aravena, R. \& Wassenaar, L.I. (1993) Dissolved organic carbon and methane in a regional confined aquifer, southern Ontario, Canada: Carbon isotope evidence for associated subsurface sources. Applied Geochemistry, 8, 483-493.

Bethke, C. \& Johnson, T.M. (2008). Groundwater Age and Groundwater Age Dating. Annual Review of Earth and Planetary Sciences, 36, 121-152.

Burgess, W.G., Ahmed, K.M., Carruthers, A., Cheetham, H., Cobbing, J., Cuthbert, M., Mather, S. \& McCarthy, E. (2007). Trends in Arsenic concentration at tubewells in Bangladesh: conceptual models, numerical models and monitoring proxies. In: Trace Metals and other Contaminants in the Environment. Bhattacharya, P., Mukherjee, A.B., Bundschuh, J., Zevenhoven, R. \& Loeppert, R.H. (eds), pp. 63-84, Elsevier B.V.

Clark I \& Fritz P. Age dating old groundwaters: Chapter 8 In: Environmental Isotopes in Hydrogeology. 1997. Lewis Publishers/CRC Press Boca Raton/New York 328pp.

Curiale, J.A., Covington, G.H., Shamsuddin, A.H.M., Morelos, J.A. \& Shamsuddin, A.K.M. (2002). Origin of petroleum in Bangladesh. American Association of Petroleum Geologists Bulletin, 86, 4, 625-652. 
Dieng, B., Ledoux, E. \& De Marsily, G. (1990). Palaeohydrogeology of the Senegal sedimentary basin: A tentative explanation of the piezometric depressions. Journal of Hydrology, 118, 1-4, 357-371.

Dowling, C.B., Poreda, R.J., Basu, A.R. \& Peters, S.L. (2002). Geochemical study of arsenic release mechanisms in the Bengal Basin groundwater. Water Resources Research, 38, 9, 1173-91.

Dowling, C.B., Poreda, R.J. \& Basu, A.R. (2003). The groundwater geochemistry of the Bengal basin: weathering, chemisorption, and trace metal flux to the oceans. Geochimica Cosmochimica Acta, 67(12):2117-2136.

DPHE-JICA. (2006). Final Report on Development of Deep Aquifer Database and Preliminary Deep Aquifer Map. Japanese International Cooperation Agency. Report for Department of Public Health Engineering, Bangladesh, 173p.

Geyh, M.A. (2000). An overview of ${ }^{14} \mathrm{C}$ analysis in the study of groundwater. Radiocarbon, 42: 99114.

Halim, M.A., Majumder, R.K., Nessa, S.A., Hiroshiro, Y., Sasaki, K., Saha, B.B., Saepuloh, A. \& Jinno, K. (2010). Evaluation of processes controlling the geochemical constituents in deep groundwater in Bangladesh: Spatial variability on arsenic and boron enrichment. Journal of Hazardous Materials, 180, 50-62.

Hasan, M.A., Bhattacharya, P., Sracek, O., Ahmed, K.M., von Brömssen, M. \& Jacks, G. (2009). Geological controls on groundwater chemistry and arsenic mobilization: Hydrogeochemical study along an E-W transect in the Meghna basin, Bangladesh. Journal of Hydrology, 378, 105118.

Hoque, M.A. \& Burgess, W.G. (2012). ${ }^{14} \mathrm{C}$ dating of deep groundwater in the Bengal Aquifer System, Bangladesh: implications for aquifer anisotropy, recharge sources and sustainability. Journal of Hydrology, 444-445: 209-220. 
Kreitler, C.W. (1989). Hydrogeology of sedimentary basins. Journal of Hydrology, 106, 1-2, 2953.

Lambeck, K., Rouby, H., Purcell, A., Sun, Y., \& Sambridge, M. (2014). Sea level and global ice volumes from the Last Glacial Maximum to the Holocene. Proceedings of the National Academy of Sciences, 111, 15296-15303.

Majumder, R., Halim, M., Saha, B., Ikawa, R., Nakamura, T., Kagabu, M. \& Shimada, J. (2011). Groundwater flow system in Bengal Delta, Bangladesh revealed by environmental isotopes. Environmental Earth Sciences, 64(5), 1343-1352.

PHED. (1991). Arsenic pollution in groundwater in West Bengal. Public Health Engineering Department; Govt of West Bengal.

Rousseau-Gueutin, P., Love, A.J., Vasseur, G., Robinson, N.I., Simmons, C.T. \& de Marsily, G. (2013). Time to reach near-steady state in large aquifers. Water Resources Research, 49, 10, 6893-6908.

Roy, D.K., Ray, G.K. \& Biswas, A.K. (2010). Overview of overpressure in Bengal Basin, India. Journal of the Geological Society of India, 75, 644-660.

Sanford, W.E. (1997). Correcting for diffusion in Carbon-14 dating of ground water. Ground Water, 35, 2, 357-364.

Zahid, A., Hassan, M.Q., Balke, K-D., Flegr, M. \& Clark, D.W. (2008) Groundwater chemistry and occurrence of arsenic in the Meghna floodplain aquifer, southeastern Bangladesh. Environmental Geology, 54(6):1247-1260. DOI 10.1007/s00254-007-0907-3. 